\title{
Fenologia de espécies florestais em floresta tropical úmida de terra firme na Amazônia Central
}

\author{
Juradndyr da Cruz Alencar ( ${ }^{*}$ ) \\ Raimundo Aniceto de Almeida ( $\left.{ }^{(}\right)$ \\ Noeli Paulo Fernandes (")
}

\begin{abstract}
Resumo
O trabalho apresenta as observações fenológicas de vinte e sete espécies florestais da floresta Iropical úmida de terra firme, localizadas na Reserva Ducke, durante o período de 1965 a 1976. Foram analisadas a floração, frutificação e mudança foliar. As observações foram feitas em árvores separadas, ccupando diferentes estratos da floresta. Durante 12 anos de obscrvaçōes, mostra-se a periodicidade cic início da floração e frutificação para cada espéc1e, em conjunto, e em dois diferentes estratos da floresta (dossel e dossel inferior). As árvores foram selecionadas na floresta, considerando-se as bem representativas de cada espécie, pelo valor econômico nos mercados local, nacional e internacional, como produtora de madeira, óleo essencial, resina, goma, látex e frutos; e ótimas características fenotípicas como uma possivel porta-semente. São apresentadas também as épocas mais prováveis de ocorrência e đuração da floração e frutifiração para cada espécie e as respectivas características dendrológicas e botânicas. Para as espécies em conjunto, que iniciaram a florar e frutificar em dois estratos (dossel e dossel inferior), procedeu-se à análise não paramétrica, que revelou serem as duas amostras significativamente diferentes, mostrando que a posição da copa é um importante fator de comportamento fenológico. Foi feita ainda a análise de regressão, correlacionando o número de árvores que iniciaram a florar e frutificar com os fatores climáticos (precipitação, umidade relativa e temperatura máxima absoluta), análise que mostrou uma tendência de ser abservado maior número de árvores, iniciando a florar e frutificar, quando ocorrem menores valores de precipitaçāo e umidade relativa. A temperatura máxima absoluta foi não significativa para a floração mas foi significativa, positiva $(0,1 \%)$ para a frutificação.
\end{abstract}

\section{INTRODUÇÃo}

Reamur, em 1735 (Wielgolaski, 1974), foi o primeiro a estudar matematicamente a relação entre a temperatura e o valor dos processos biológicos. O termo "Fenologia" foi pro- posto pelo botânico belga Charles Morren, em 1853 (Hopp, 1974), sendo entretanto considerado "pai" da fenologia de plantas o botânico sueco Carl von Linné que em sua obra Filosofia Botânica (1751) delineou métodos para construir calendários anuais de plantas (abertura das folhas, floração, frutificação e queda das folhas) em conjunto com observaçōes meteorológicas.

Este trabalho, que consta do estudo de 27 espécies florestais, faz parte dos "Estudos Fenológicos da Reserva Ducke" ( \pm 100 espécies), iniciado em 1962 pelo Eng ${ }^{\circ}$ Agr. $^{\circ}$ Vivaldo Campbell de Araujo, que publicou, em 1970, dados fenológicos de 36 espécies no período de 1962 a 1968. Os dados agora analisados referem-se a obșervações feitas no período compreendido entre os anos de 1965 e 1976. com objetivos de possibilitar a coleta de sementes de modio racional na época mais provável, para cada espécie; possibilitar a avaliação da quantidade de sementes por espécie; possibilitar informações sobre a Biologia das espécies (reprodução, crescimento, etc.); estudar a dinâmica da floresta nos diversos estratos da cobertura.

ÁREA DE ESTUdo

LOCALIZAÇÃO

A área está localizada na Reserva Ducke, $\mathrm{Km} 26$ da Rodovia Manaus-Itacoatiara, compreendendo aproximadamente 300 hectares em floresta tropical úmida de terra firme.

CLINIA

Segundo Ribeiro (1976), o clima da área de estudo (dados meteorológicos coletados na Reserva Ducke no período de 1965 a 1973, cuja Estação Meteorológica se encontra dentro

$\left({ }^{*}\right)$ - Instituto Nacional de Pesquisas da Amazônia, Manaus. 
da própria área) é do tipo Afi, de acordo com a classificação climatológica de Köppen: A Clima tropical praticamente sem inverno, a temperatura média para o mês mais frio nunca é inferior a $18^{\circ} \mathrm{C} ; \mathrm{f}$ - Chuvas durante todo o ano; $\mathrm{i}$ - Indica isotermia, uma vez que as oscilaçōes anuais de temperatura média não chegam a $5^{\circ} \mathrm{C}$; não há propriamente verão nem inverno.

Anualmente, verifica-se na área fenômeno de friagem quando a temperatura tende a diminuir. Brinkmann et al. (1971) relataram o fenômeno numa área de regeneração natural, próxima à dita Estação Meteorológica, entre os dias 10 e 13 de julho de 1969, quando a temperatura baixou até $15^{\circ} \mathrm{C}$ voltando após algumas horas a apresentar variaçōes face ao movimento turbulento das camadas de ar.

O clima da area, segundo a classificaçăo climatológica de Thornthwaite (1948), é do tipo B3 $A^{\prime} a^{\prime}$ ', sendo: "úmido com pequena ou nenhuma deficiência hidrica, megatérmico, com evapotranspiraçăo potencial igualmente distribuida no ano todo" (Ribeiro, 1976) .

\section{VEGEIAÇÃO}

A floresta é do tipo tropical úmido de terra firme, caracterizada pela grande diversidade de espécies arbóreas, arbustivas e herbáceas.

As espécies mais características do andar emergente (veja Fig. 3) da mata estudada são: "Angelim-pedra" (Dinizia excelsa Ducke). "Ucuúba-branca" (Osteophloeum platysper. mum (A.D.C.) Warb.), "Copaiba-roxa" (Copaifera multijuga Hayne), "Marirana" (Emmotum glabrum Btin. ex Miers), "Violeta" (Peltogyne catingae Ducke subsp. glabra (W. Rodr.) M. F. da Silva), "Castanha-de-macaco" (Cariniana micrantha Ducke), "Tachi-preto" (Tachigalia paniculata Aubl.). "Faveira-benguê" (Parkia oppositifolia Spr. ex Bth.). "Piriquiteira-amatela" (Laetia procera (Proepp \& Endl.) Erichl.), "Faveira-orelha-de-macaco" (Enterolo. bium shomburgkii Bth.). "Sucupira-cho:ona" (Andira unifoliolata Ducke), "Uchi-coroa" (Duckesia verrucosa (Ducke) Cuatr.

No dossel encontram-se "Ucuúba-preta" (Virola michelii Heckel), "Louro-gamela" (Nectandra rubra (Mez.) C. K. Allen), "Seringa-ver- melha" (Hevea guianensis Aubl.), "Amapá-roxо" (Brosimum parinarioides Ducke spp. parinarioides), "Louro-aritu" (Licaria aurea (Huber/Kosterm.)), "Tachi-pitomba" (Tachiga. lia sp.). "Cumaru" (Dipterix odorata (Aubl.) Willd.), "Cajuí" (Anacardium spruceanum Bth.) e "Cedrorana" (Cedrelinga catenatormis Ducke) .

No dossel inferior, as mais comuns são: "Macaranduba" (Manilkara surinamensis (Miq.) Dub.), "Mulateiro" (Peltogyne paniculata Bth. subsp. paniculata). "Sorva-grande" (Couma macrocarpa Barb. Fiodr.). "Carnba" (Jâcaranda cf. copaia (Aubl.) D. Don), "Maca. caúba" (Platymiscium cf. duckei Huter), "Aca. pu" (Vouacapoua pallidior Ducke), "Cardeiro" Scleronema micranthum Ducke). "Quarubarana" (Erisma fuscum Ducke) .

São características do subosque superior as espécies: "Cumarurana" (Dipteryx alata Vogel), "Louro-ferro" (Aniba sp.). "Anani" (Simphonia globulifera L.), "Maueira" (Erisma bicclor Ducke). "Macucu-murici" (Vantanea parviflora Lam.).

No subosque inferior, encontramos "Ma. cucu-chiador" (Licania heteromorpha Benth. var. heteromorpha) "Ucuuba-peluda" (Virola multinervia Ducke), "Pupunharana" (Duckeo. dendron cestroides Kuhim.\}. "Gitó" (Trichilia septentrionalis C. DC. J e palmeiras, tais como "Murumuru" (Astrocaryum murumuru Mart.). "Bacaba" (Oenocarpus bacaba Mart.). "Patauá" (Jessenia bataua (Mart.) Burret) e "Açai-da-terra-firme" (Euterpe precatoria Mart.)

A vegetaçăo corresponde ainda, segundo a classificação das associações floristicas de Ducke \& Black, 1953 (Klinge \& Sioli, 1962), à Floresta Tropical Pluvial, Floresta Pluvial Amazônica. Hiléia (mata de Terra Firme), assentada ein solos dos tipos barro marrom ("Braun. lehni") e barro marrom lateritico.

\section{MATERIAL E MÉTODOS}

O estudo engloba 27 espécies florestais diferentes (Tabela 3), com três repetiçūes para cada espécie, totalizando 81 árvores. As árvores foram escolhidas na floresta numa área de \pm 300 ha, levando em consideração os se. guintes fatores: 
1. Arvore madura bem representativa da espécie;

2. Valor econômico da espécie como produtora de madeira ou de óleos essenciais, resinas, gomas, látex e frutos, conhecida nos mercados local, nacional e internacional;

3. Otimas características fenotípicas gerais da árvore como uma possível porta-semente :

(Circunferência do tronco C.A.P., forma do fuste, forma e posição da copa, diâmetros da copa, altura do fuste comercial e altura total;.

As árvores assim selecionadas foram numeradas com uma placa de identificação de aluminio e pintadas com uma faixa estreita circunferencial à altura de $1,30 \mathrm{~m}$ acima do solo ou $30 \mathrm{~cm}$ acima do ponto onde as sapopemas terminam, a fim de definir o ponto de medição da C.A.P. (circunferência à altura do peito). Para cada árvore foram colhidas informações dendrológicas e dendrométricas para complementar a fenologia.

A circunferência dos troncos foi medida com fita métrica metálica de $2 \mathrm{~m}$, as alturas foram estimadas com Blume Leiss, com duas casas decimais, com a correção da declividade do terreno quando excedia $5^{\circ}$, utilizando a fórmula: $\mathrm{Hc}=\mathrm{H}-(\mathrm{H} . \mathrm{f})$, onde $\mathrm{Hc}=$ altura corrigida desejada; $\mathrm{H}=$ altura estimada com o aparelho e $f=$ fator de correçăo para a declividade do local. A forma do fuste (Fig. 1) foi registrada de acordo com Shield (1965) e a forma e posição da copa (Fig. 2 e 3) conforme o Plano de Pesquisa Silvicultural de Uganda (1956 - 1963).

Foi ainda colhido material botânico (folhas e flores e frutos, quando possível) e a identicação feita no Herbário do INPA pela Dra. Izonete Araujo, tendo alguns casos sido revistos pela Dra. Marlene Silva, Curadora do Herbário e pelo Dr. William Rodrigues.

O método para o estudo fenológico consistiu na observação mensal com binóculos (Zenith $8 X-14 \times 50$ ), tomando por base os seguintes itens :

\begin{tabular}{|c|c|c|}
\hline \multirow{2}{*}{ Código } & Fenofase & \multirow{2}{*}{ Ocorrência } \\
\hline & Floração & \\
\hline 1 & & Botões florais aparecendo \\
\hline 2 & & $\begin{array}{l}\text { Floração adiantada, árvore } \\
\text { totalmente florada }\end{array}$ \\
\hline 3 & & $\begin{array}{l}\text { Floração terminando ou ter- } \\
\text { minada }\end{array}$ \\
\hline & Frutificação & \\
\hline 4 & & Frutos novos aparecendo \\
\hline 5 & & Frutos maduros presentes \\
\hline 6 & & $\begin{array}{l}\text { Frutos maduros caindo } \\
\text { sementes dispersas }\end{array}$ \\
\hline & $\begin{array}{l}\text { Mudança } \\
\text { foliar }\end{array}$ & \\
\hline 7 & & $\begin{array}{l}\text { Arvore com pouca folha ou } \\
\text { desfolhada }\end{array}$ \\
\hline 8 & & $\begin{array}{l}\text { Arvore com folhas novas apa- } \\
\text { recendo }\end{array}$ \\
\hline 9 & & $\begin{array}{l}\text { Arvore com maioria das fo- } \\
\text { lhas novas ou totalmente } \\
\text { novas }\end{array}$ \\
\hline 10 & & $\begin{array}{l}\text { Arvore com a copa completa } \\
\text { com folhas velhas }\end{array}$ \\
\hline
\end{tabular}

O método adotado para a análise dos dados foi :

\section{Freqüência no período 1965 - 1976}

Registrou-se para cada árvore, em cada ano, no período de 1965 a 1976, os meses de ocorrência dos fenômenos para a avaliação quantitativa das três repetições e cálculo da freqüência mensal em porcentagem durante o período observado. Considerou-se a floração em conjunto, desde o aparecimento dos botões florais até o seu término; também a frutificação foi considerada de igual modo, desde o aparecimento de frutos até a disseminaçăo de frutos e sementes no solo. Quanto à mudança foliar, consideraram-se três fases: árvore com pouca folha ou desfolhada (código 7), árvore com folhas novas (códigos 8 e 9 agrupados) e árvore com folhas velhas (código 10). O estudo foi feito para cada espécie. 
P.P. S.U. (1956-63)

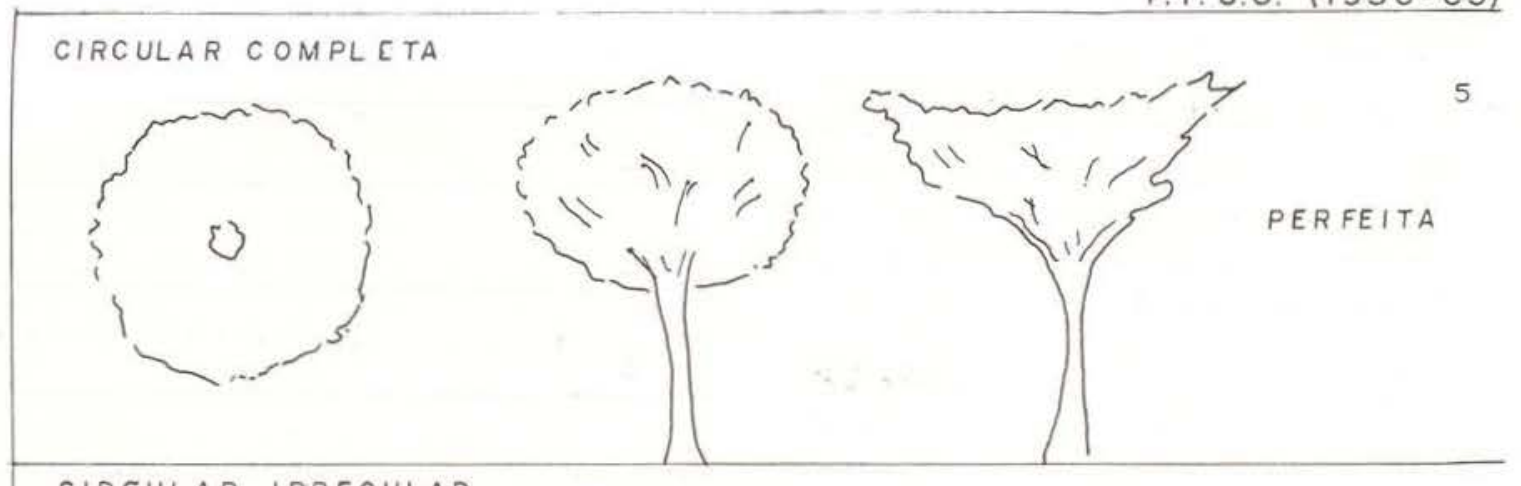

CIRCULAR IRREGULAR
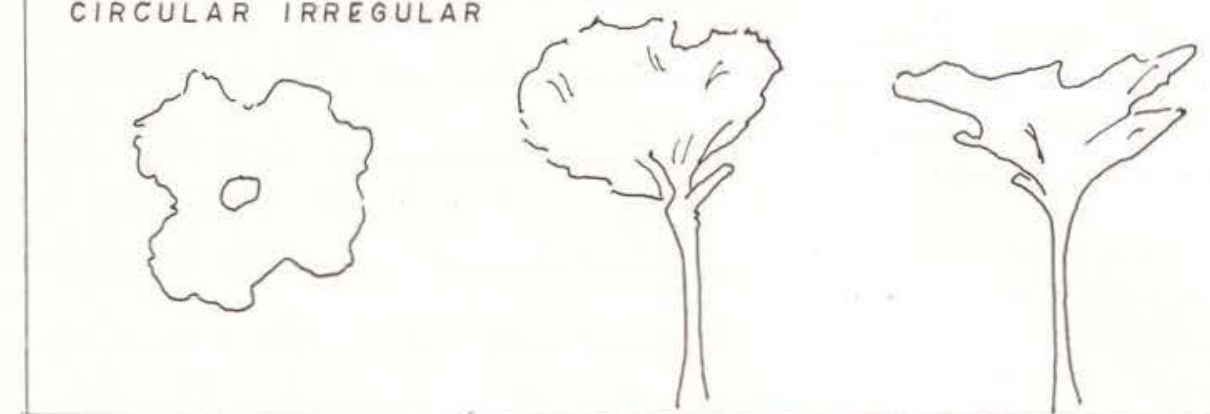

4
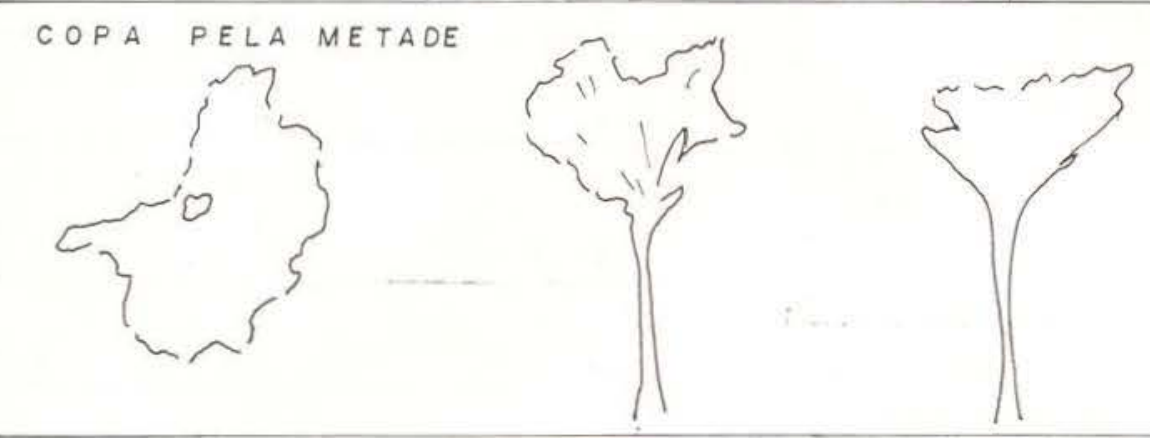

3

$B O A$

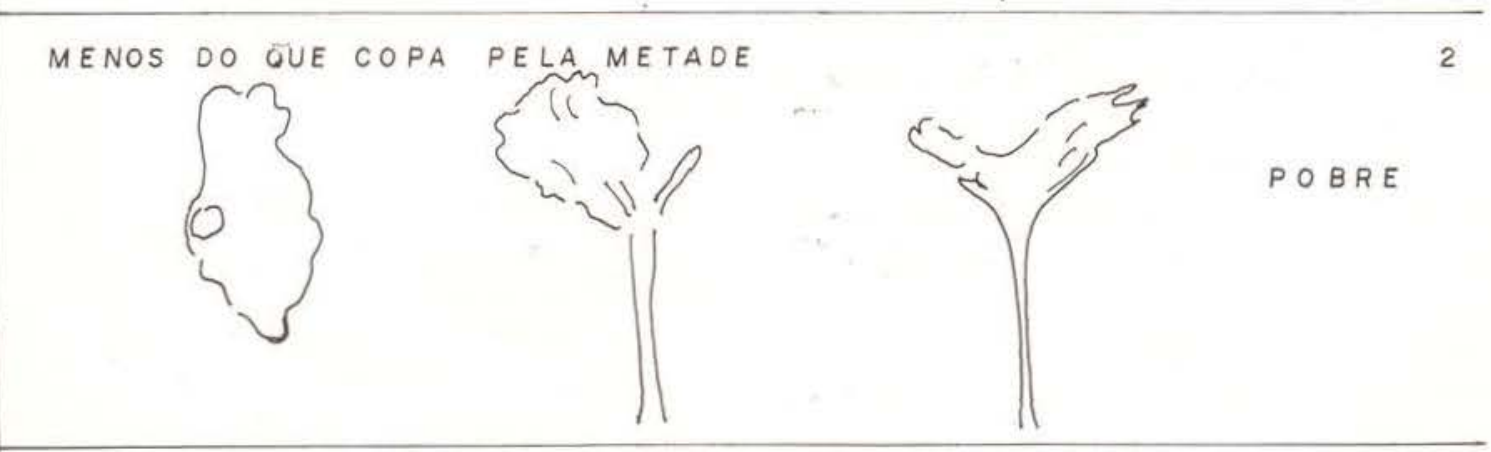

UM OU ALGUNS GALHOS

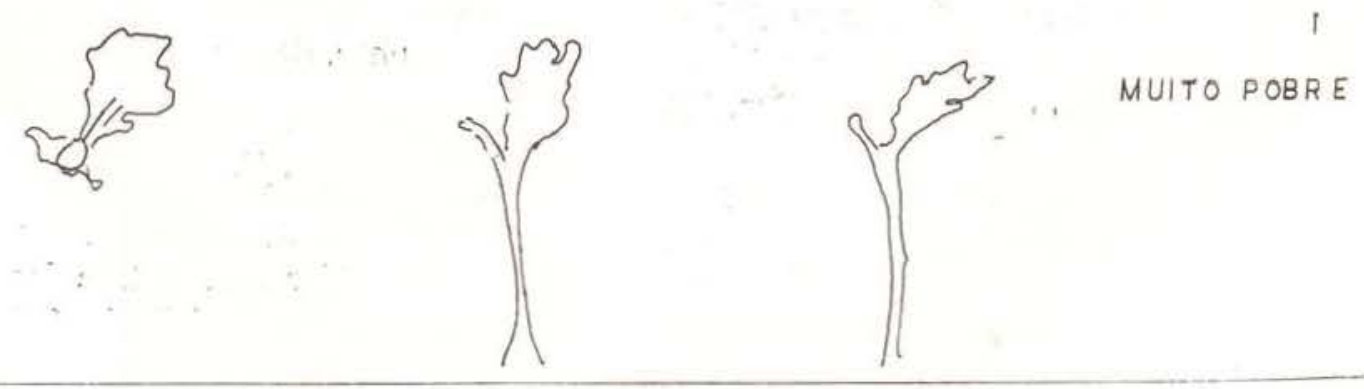

Fig. 1 - Registro de silvicultura de forma de copa 
P.P.S.U. (1956-63)
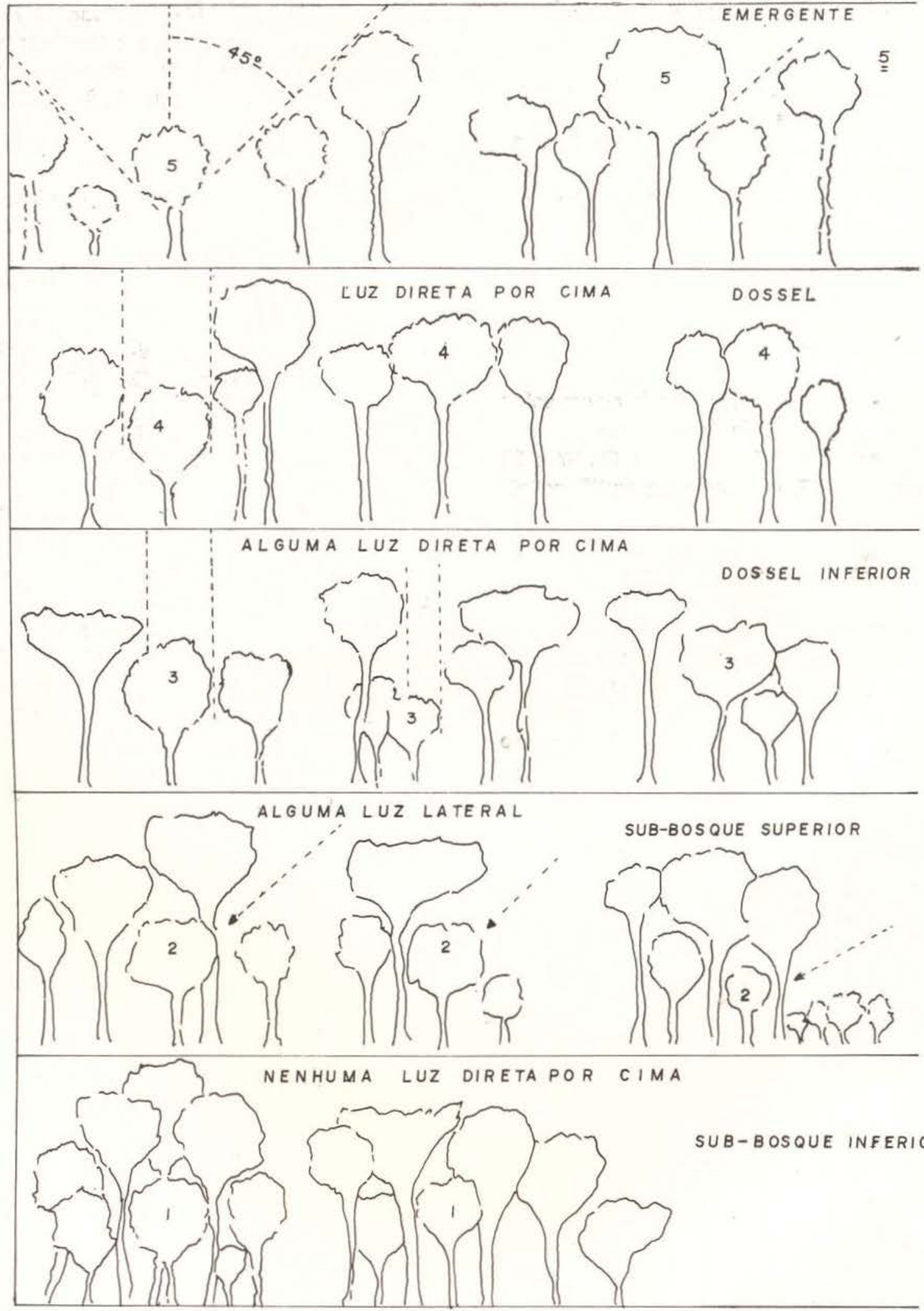

Fig. 2-Registro de silvicultura de posição da copa

Fenologia de. 
Foi anotado o mês de ocorrência do início da fenofase, em cada ano e os valores das precipitações mensais em milímetros da Estação Meteorológica da Reserva Ducke, de acordo com Ribeiro (1976 e 1977) (Veja gráficos 28, 29,30 e 31 para floração e $32,33,34$ e 35 para frutificação) .

Periodicidade do início da floração e frutificação de 81 árvores

O estudo foi feito considerando as espécies em conjunto: número de árvores que apresentaram o fenômeno. (Veja gráficơs 36,37 e 38 para floração e 39, 40 e 41 para frutificação).

Periodicidade do início da floração e frutificação em dois estratos

Foi estudada tomando por base o número de árvores que apresentaram o fenômeno, em cada mês, em dois estratos da floresta (dossel $a$ dossel inferior), de acordo com a posição da cơpa da árvore (Fig. 3). (Veja gráfico 42 para floraçãc e 43 para frutificação) . unla das uuas amustras para veriticar a nıpotese nula de que as duas amostras provêm da mesma população com relação às médias, conforme a expressão :

$H=\frac{12}{N(N+1)} \sum_{j=1}^{K} \frac{R_{j}^{2}}{N j}-3(N+1)$

\section{Duração da floração e frutificação por espécie}

Em cada ano, foi registrada a duração em meses, para as três repetições, o intervalo observado em meses, a duração mais freqüente no período estudado e a freqüência da duração tanto para a floração como para a frutificação (Veja Tabelas 3, 4 e 5).

\section{Tempo de vida da folha e tipos de mudança} foliar

Determinou-se o tempo de vida da folha, para cada espécie, através do intervalo em meses, entre o aparecimento de folhas novas e a mudança foliar seguinte. A classificação dos tipos de mudança foliar foi analisada de acordo com as quatro fases (códigos $7,8,9 \mathrm{e}$ 10) com as da floração (códigos 1,2 e 3) e frutificação (códigos 4,5 e 6) .

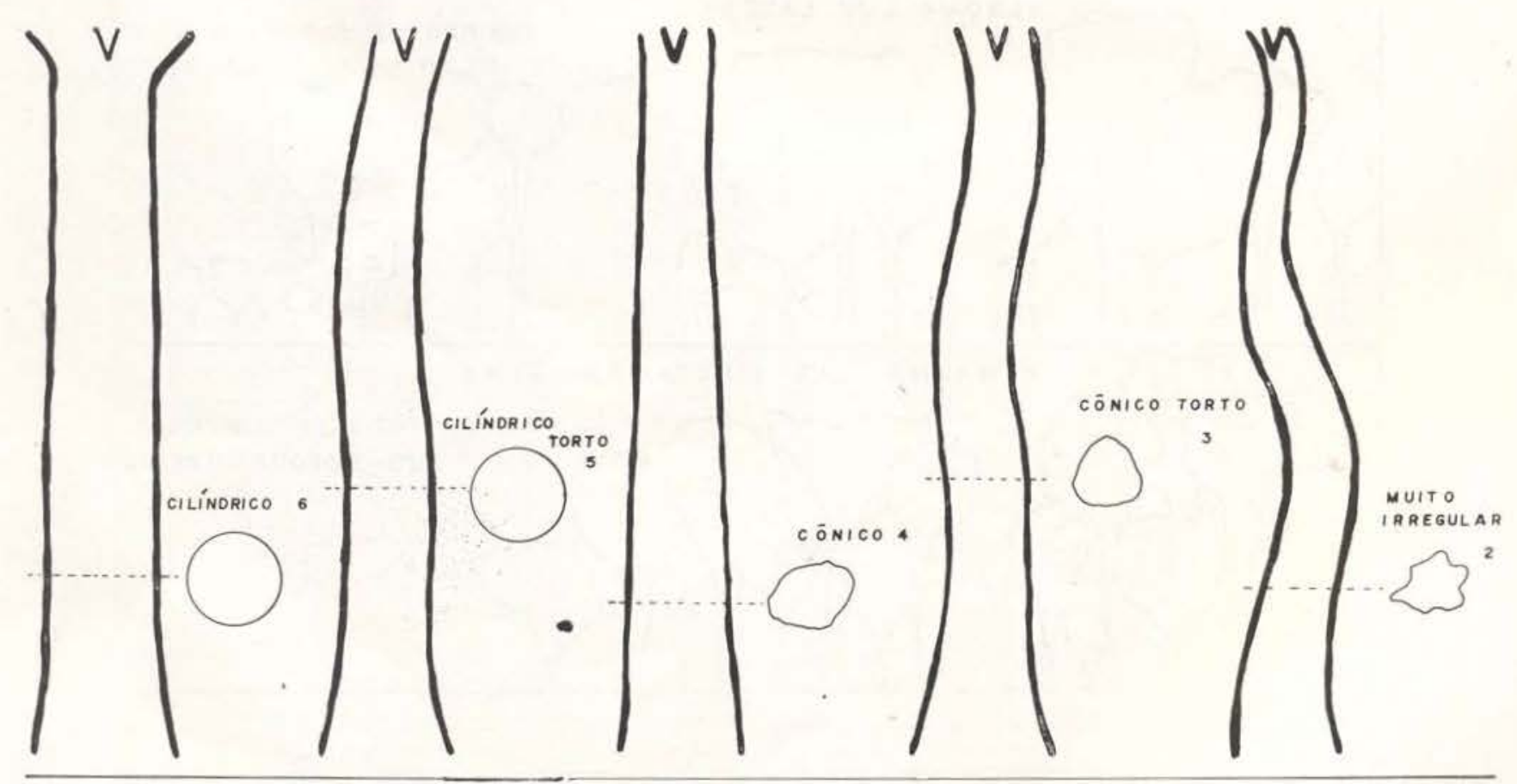

Fig. $3-$ Registro de slvicultura do fuste E.D. Shield (1965) 


\section{Análise de regressão simples}

Procedeu-se à análise de correlação entre o número de árvores que iniciaram a florar (gráticos 36, 37 e 38) e frutificar (gráficos 39, 40 e 41) com os valores da precipitação em milímetros, umidade relativa em \% e temperatura máxima absoluta em graus centígrados (dados obtidos de Ribeiro 1976 e 1977).

\section{Resultados}

A FOKMA E POSIÇÃO DAS COPAS DAS 81 ÁRVORES ESTUDADAS

Conforme as figuras 1 e 2, mostram (Fig. 4 e 5) que $92,60 \%$ das árvores apresentam a forma da copa entre perfeita, boa e tolerável e $7,4 \%$ entre copa pobre e muito pobre; $11,11 \%$ das árvores são emergentes, $40,74 \%$ fazem parte do dossel, $41,98 \%$ estão no dossel inferior, $2,47 \%$ no subosque superior e $3,70 \%$ no subosque inferior. Veja a forma e posição das copas para cada espécie com três repetiçōes (tabela 7).

FREQÜÊNCIA DE OCORRÊNCIA EM \% DA FLORAÇÃO, FRUTIFICAÇÃO E MUDANÇA FOLIAR NO PERÍODO $1965-1976$.

Apresentamos nos gráficos ( 1 a 27) as freqüências de ocorrência em \% para cada espé-

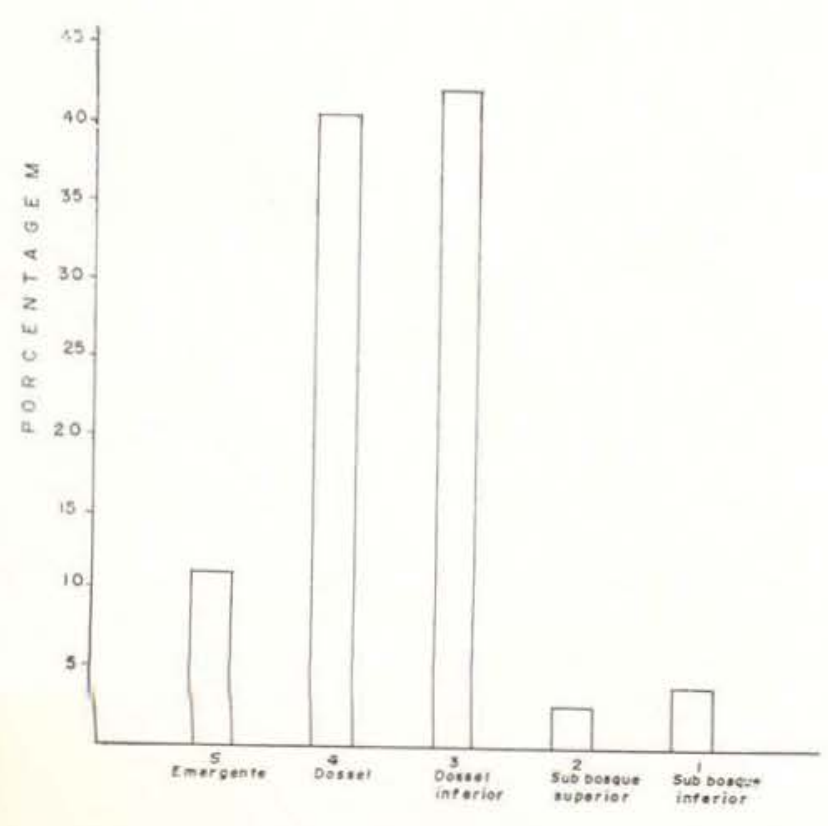

Fig. 4 - Posição da copa das 81 árvores cie. Vê-se que é variável a ocorrência dessas fenofases de espécie para espécie, não havendo nem duas sequer que apresentem a mesma curva. Entretanto, algumas espécies apresentaram. ocorrência mais ou menos em períodos comuns e foram separadas em grupos (Tabelas 1 e 2).

Verifica-se pela Tabela 1 que $62.96 \%$ das espécies estudadas apresentam a floração entre julho e dezembro, período caracterizado por estação seca (Grupos 4, 5 e 6); $37,04 \%$ floram entre novembro e agosto, período de maior precipitação (Grupos 1, 2, 3 e 7). Quanto à frutificação, $70,38 \%$ das espécies frutificam entre setembro e maio (Grupos 7, 8, 9, 10 e 1), período de maior precipitação e somente $14,81 \%$ entre julho e dezembro (Grupos 4, 5 e $6)$, período de estação seca e $14,81 \%$ entre janeiro e agosto (Grupos 2 e 3), período de transição entre a estação chuvosa e a seca.

Quanto à mudança foliar, verifica-se que $70,37 \%$ das espécies estudadas apresentam a

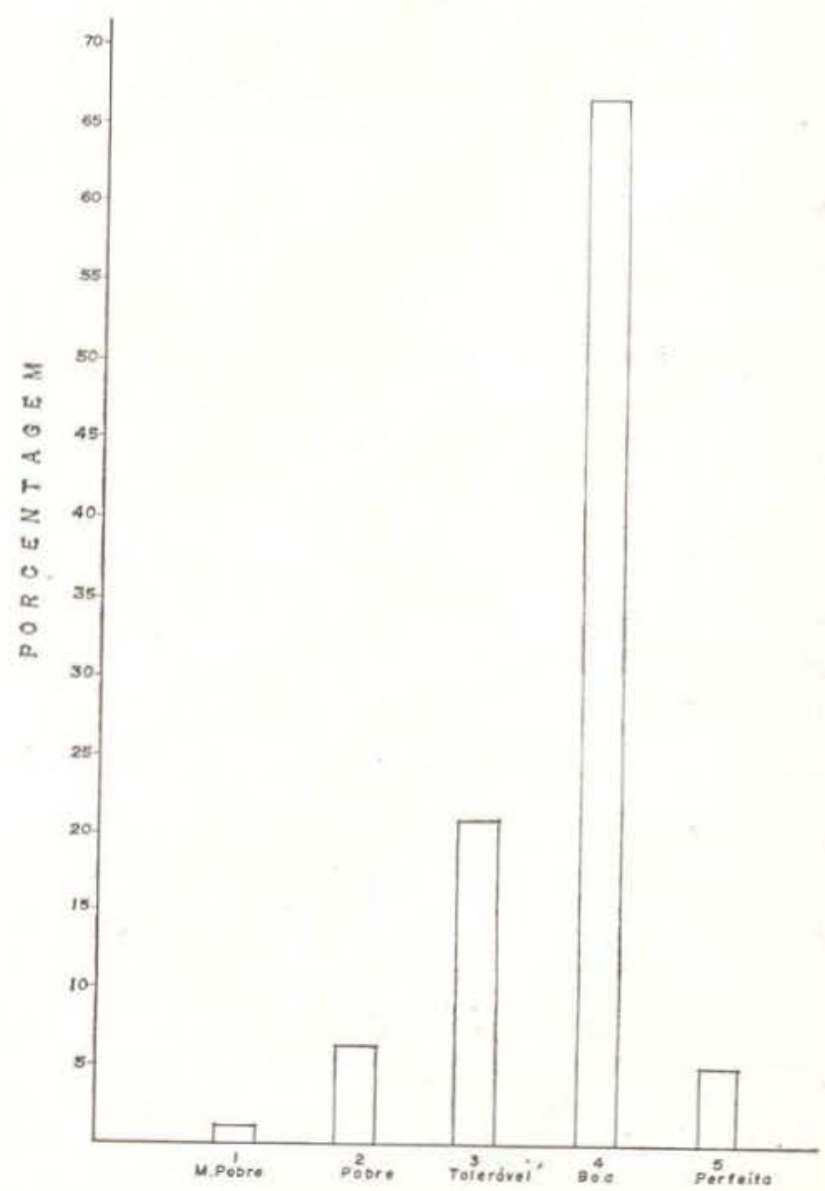

Fig. 5 - Forma da copa das 81 árvores

Fenologia de... 


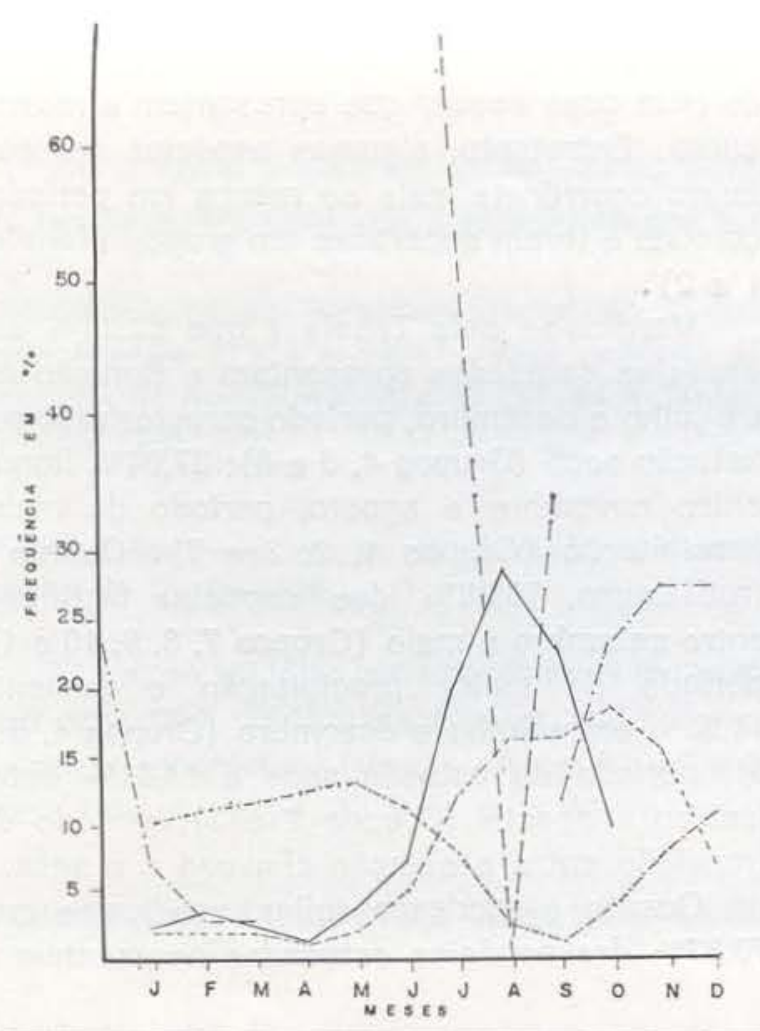

Gráfico 1 - Freqüência no periodo 1965-1976 em \% UCUÚBA-PRETA (Virola michelii Heckel)

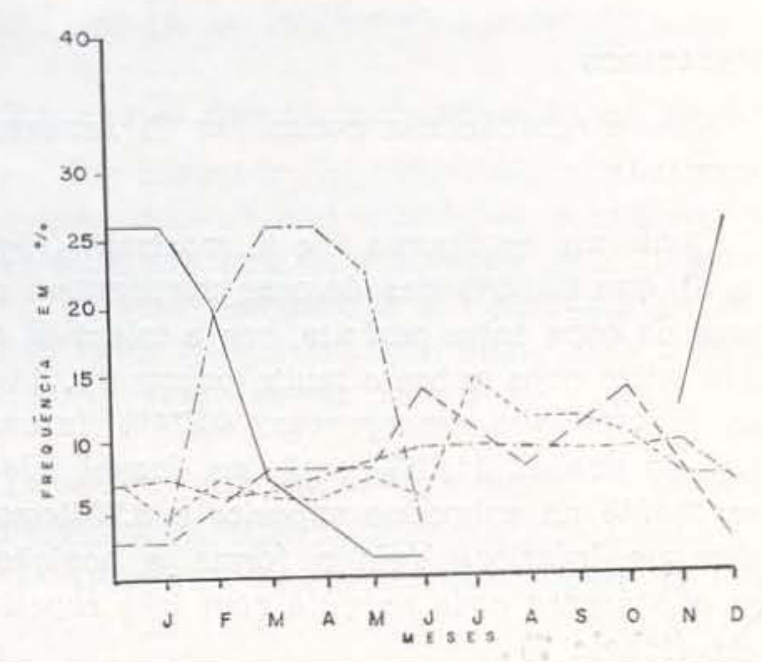

Gráfico 2 - Frequiência no período 1965-1976 em \% ACAPU (Voucapoua pollidior Ducke)

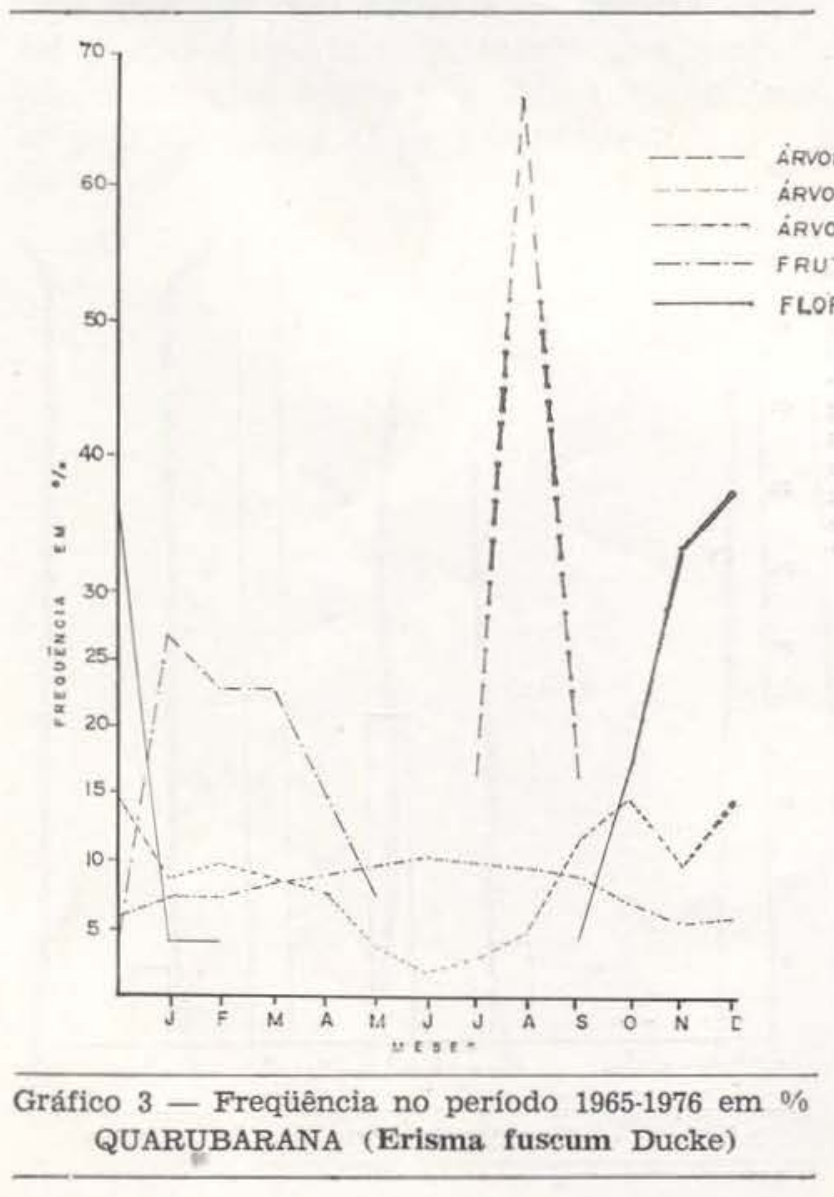




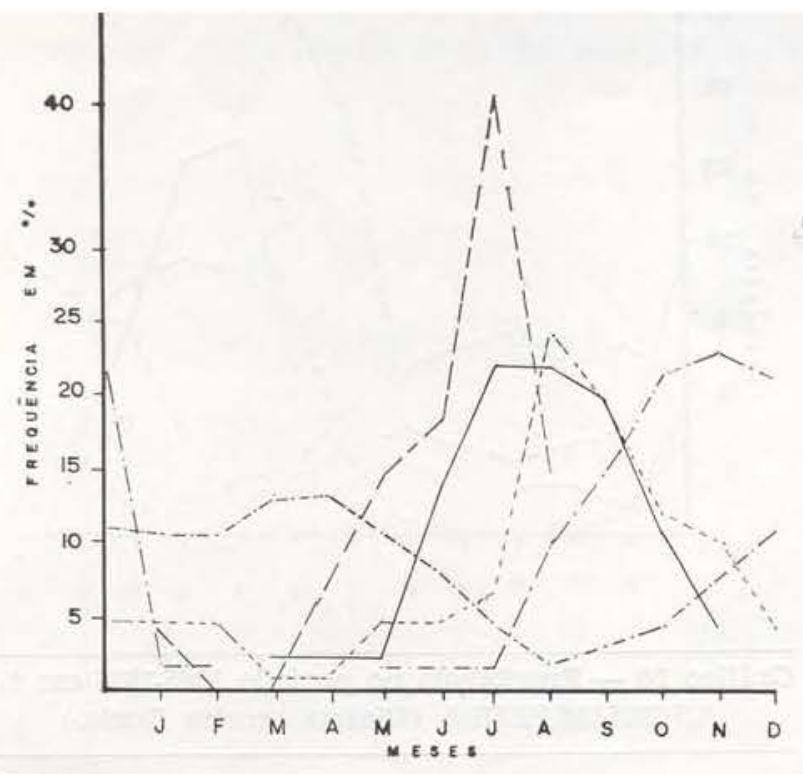

Gráfico 5 - Frequiência no período 1965-1976 em \% LOURO-GAMELA (Nectandra rubra (Mez) C.K. Allen)

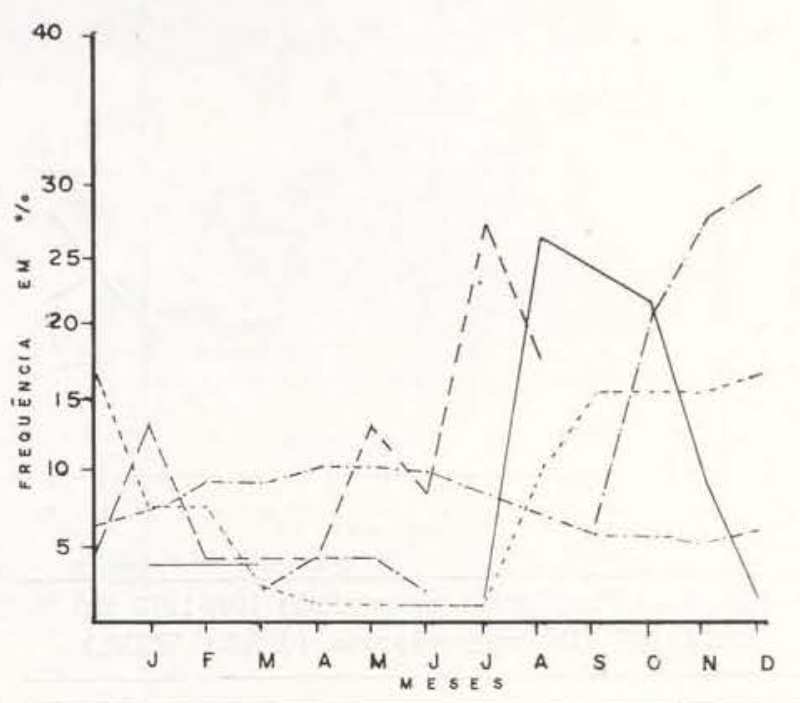

Gráfico 6 - Frequiência no período 1965-1976 em \% CAROBA (Jacaranda cf. copaia (Aubl.) D. Don)

FLORAÇĀO

FRUTIFICACĀO

ÁRVORE COM POUCA FOLHA OU DESFOLHADA

- ARVORE COM FOLHAS NOVAS

-... ARVORE COM FOLHAS VELHA

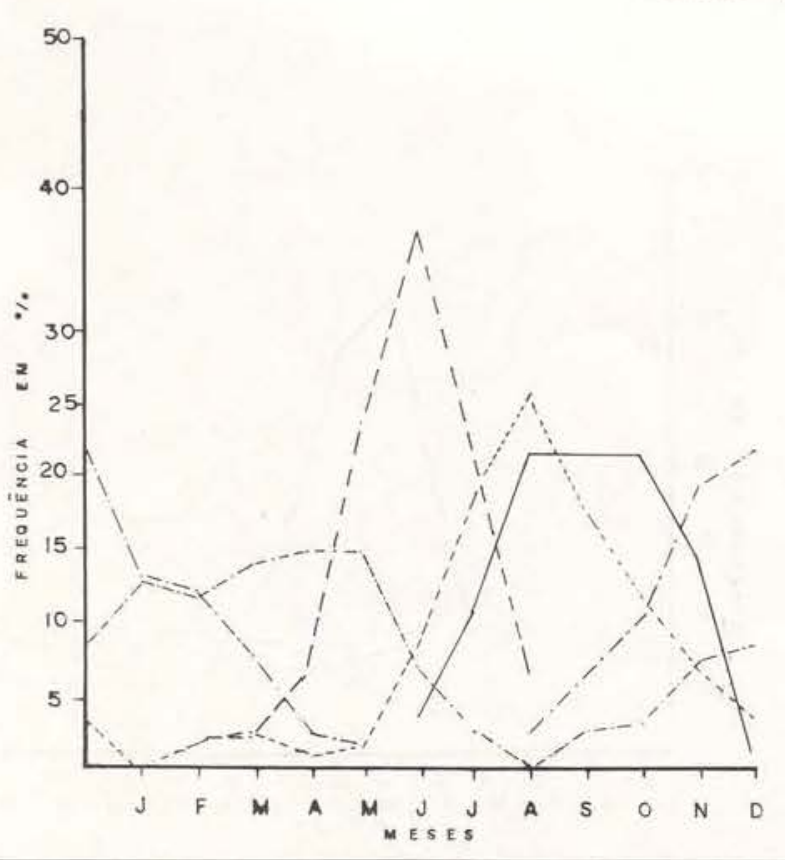

Gráfico 7 - Frequiência no periodo 1965-1976 em \% SERINGA-VERMELHA (Hevea guianensis Aubl.)

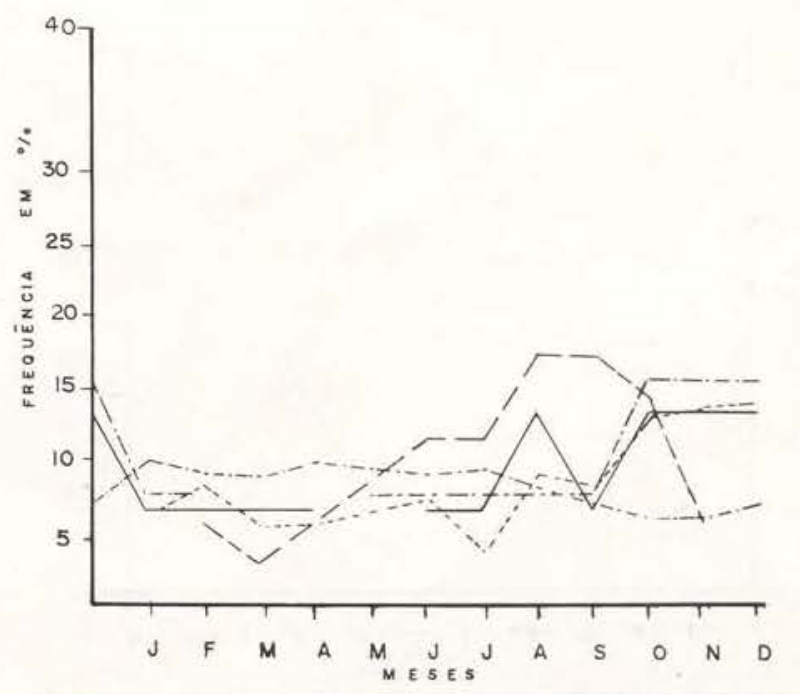

Gráfico 8 - Freqüência no período 1965-1976 em \% MACACAƯBA (PIatymiscium cf. duckei Huber)

Fenologia de... 


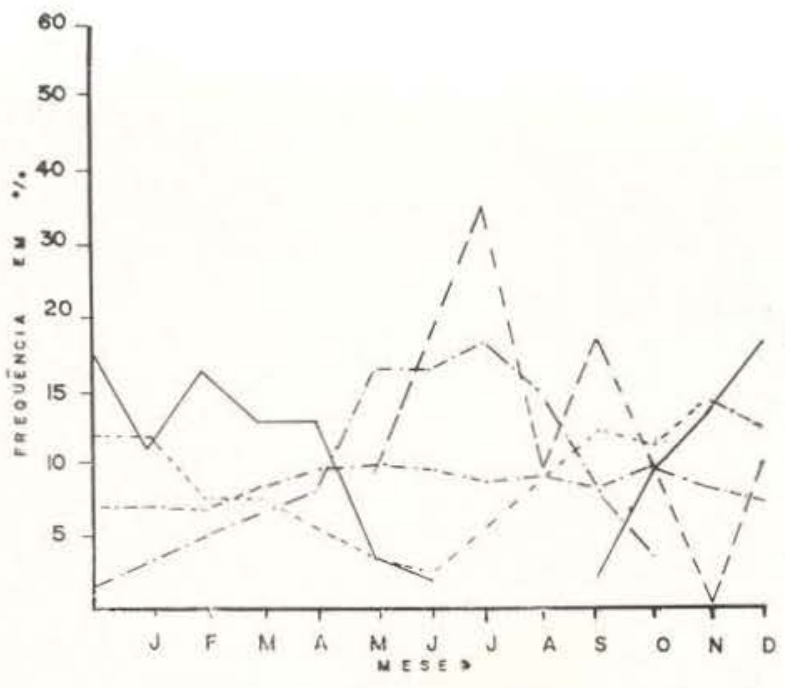

Gráfico 9 - Frequiência no período 1965-1976 em \% CUMARU (Dipteyx odorota (Aubl.) Willd.)

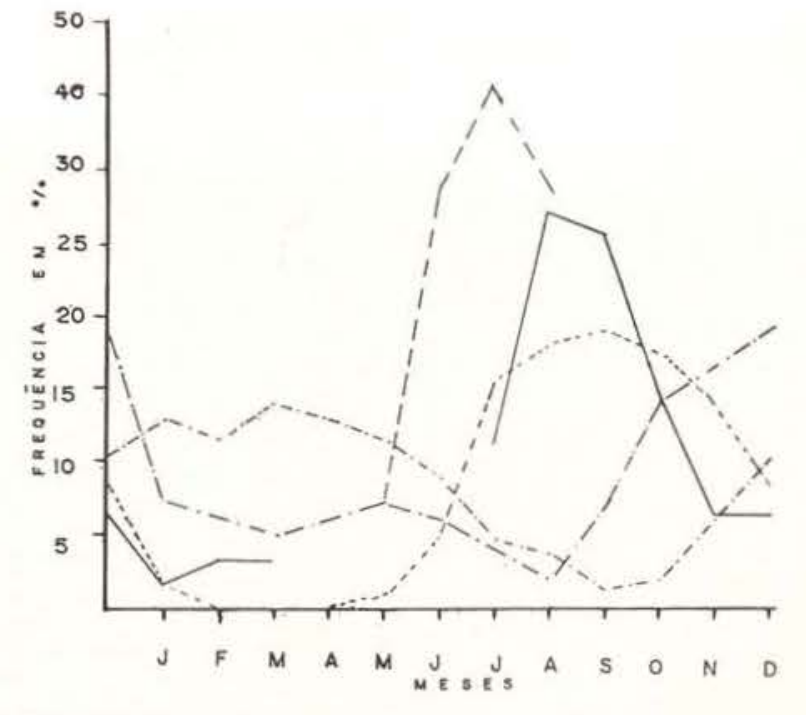

Gráfico 10 - Frequiência no período 1965-1976 em \% ANGELIM-PEDRA (Dinizia excelsa Ducke)

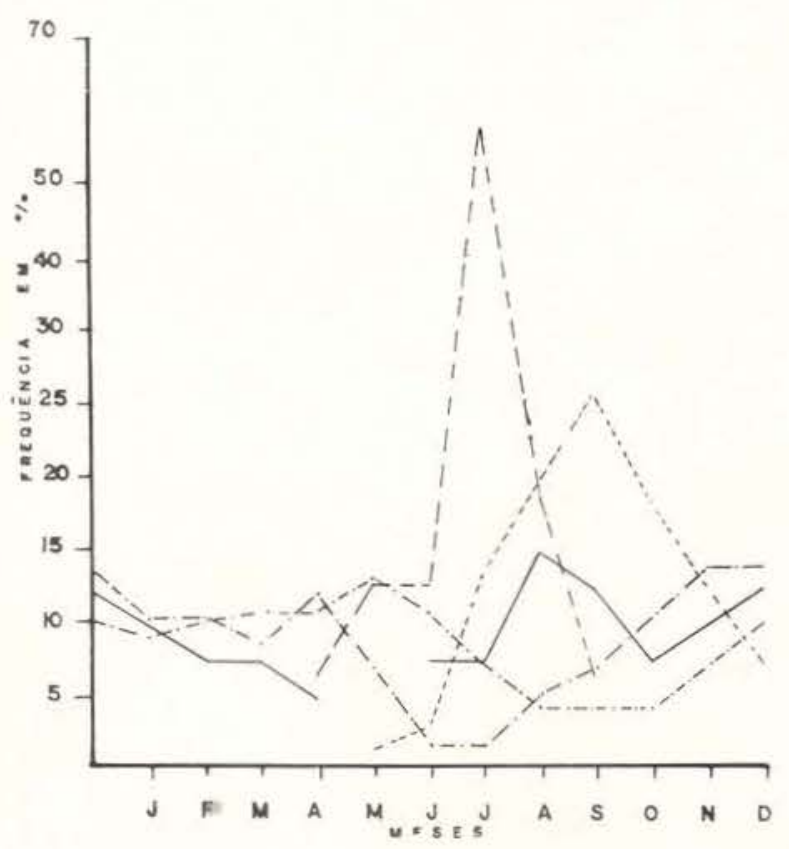

Gráfico 11 - Freqüência no período 1965-1976 em \% SORVA-GRANDE (Couma macrocarpa Borb. Rodr.)

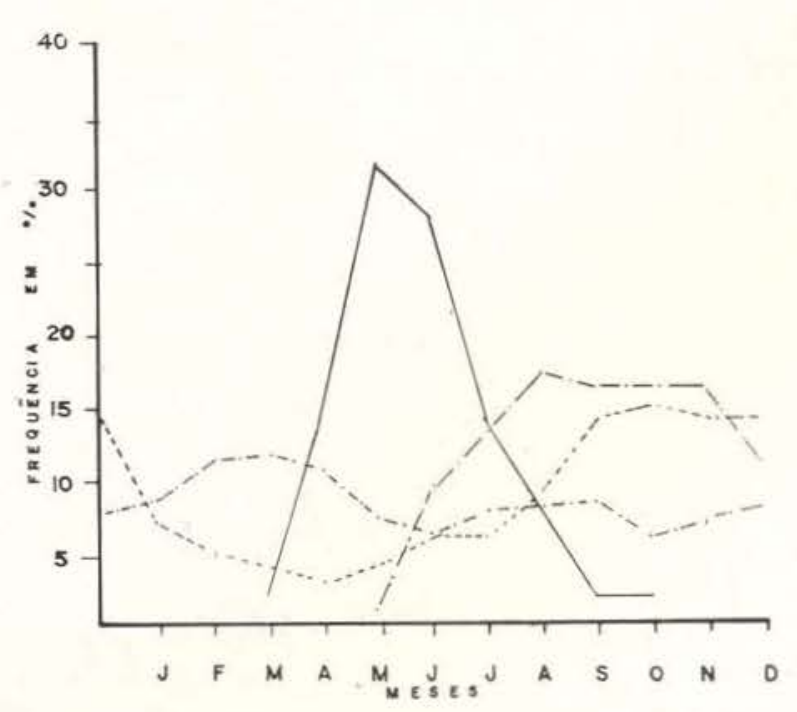

Gráfico 12 - Frequêência no período 1965-1976 em \% JACAREUBA (Calophyllum angulare A. C. Smith) 


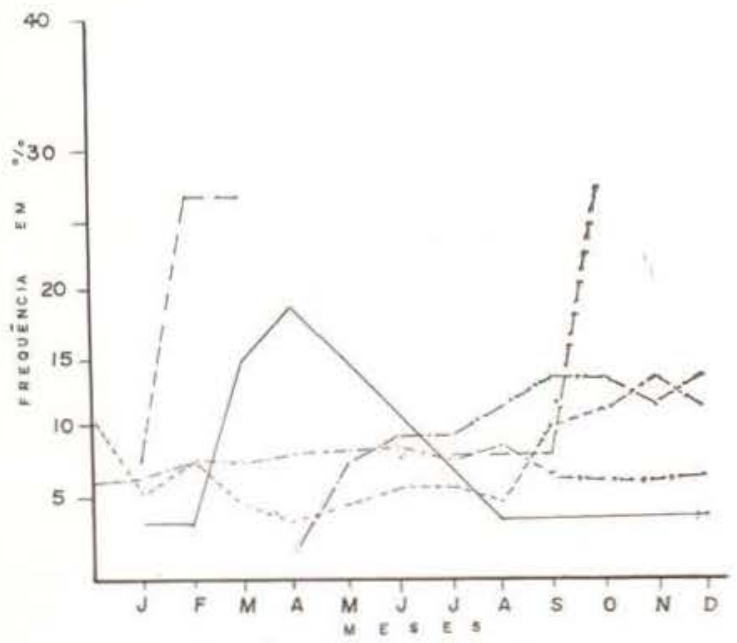

Gráfico 13 - Freqüência no período $1965-1976$ em \% SUCUPIRA-CHORONA (Andira unifoliolata Ducke)

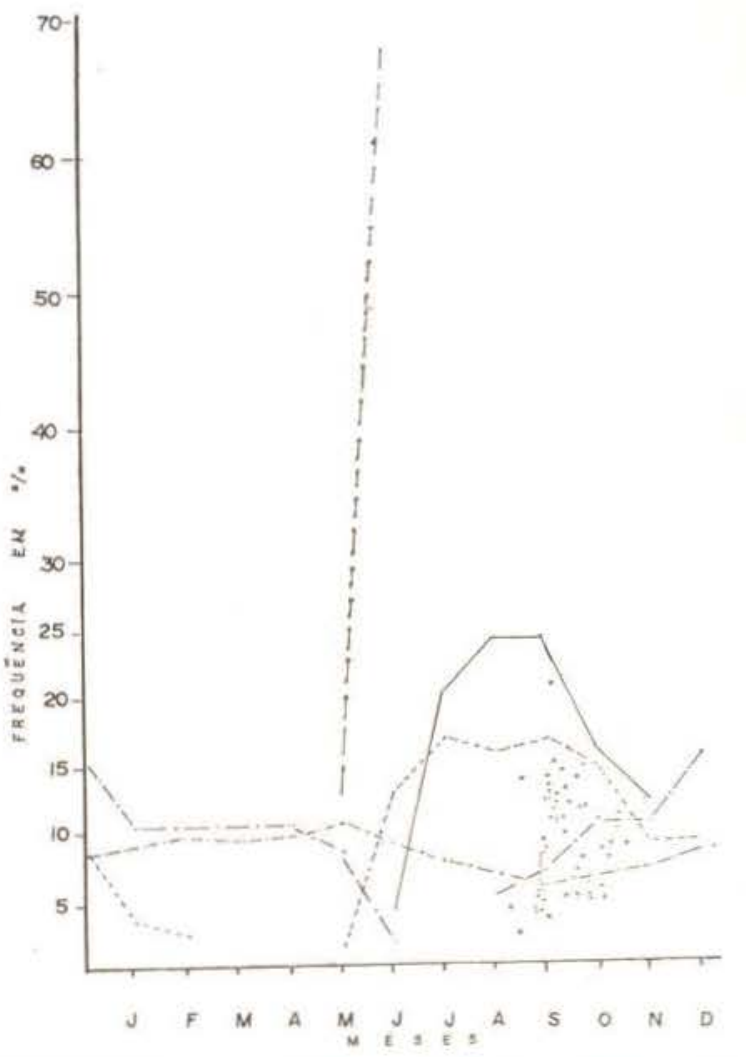

Gráfico 14 - Frequiência no periodo 1965-1976 em \% CASCA-PRECIOSA (Aniba canelilla (H.B.K.) Mez.)

- FRUTIFICACÃo

- - ÁRVORE COM POUCA FOLHA OU DESFOLHADA

- ARVORE COM FOLHAS NOVAS

A'RVORE COM FOLHAS VELHA

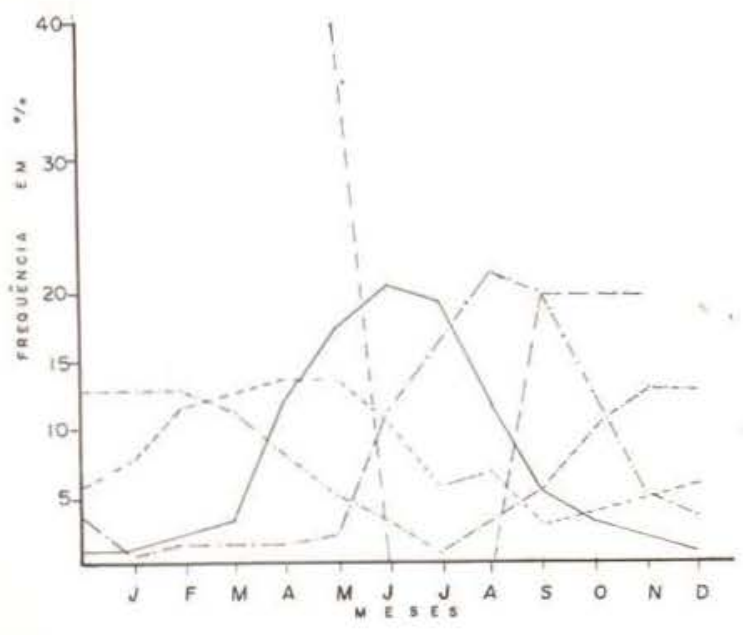

Gráfico 15 - Freqüência no período 1965-1976 em \% CUPIƯBA (Goupia glabra Aubl.)

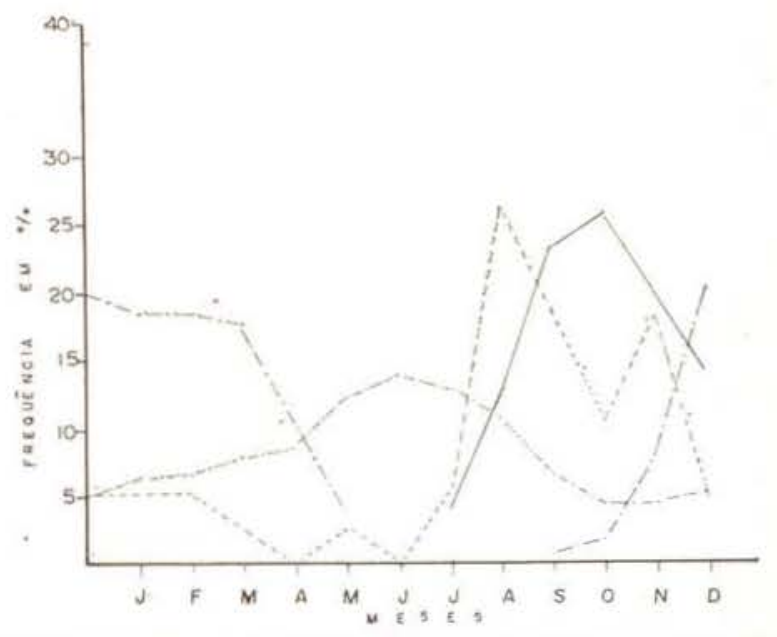

Gráfico 16 - Frequêencia no período 1965-1976 em \% UCUÜBA BRANCA (Osteophoeum platyspermum (A.D.) Warb.)

Fenologia de.. 


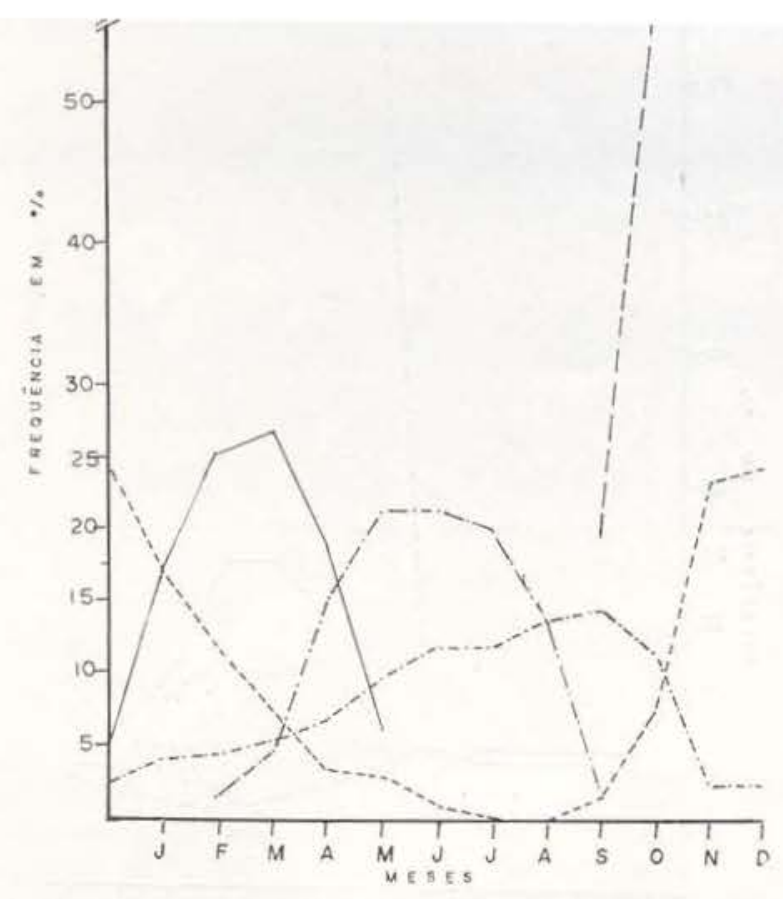

Gráfico 17 - Frequiência no período 1965-1976 em \% COPAFBA-ROXA (Copaifera multijuga Hayne)

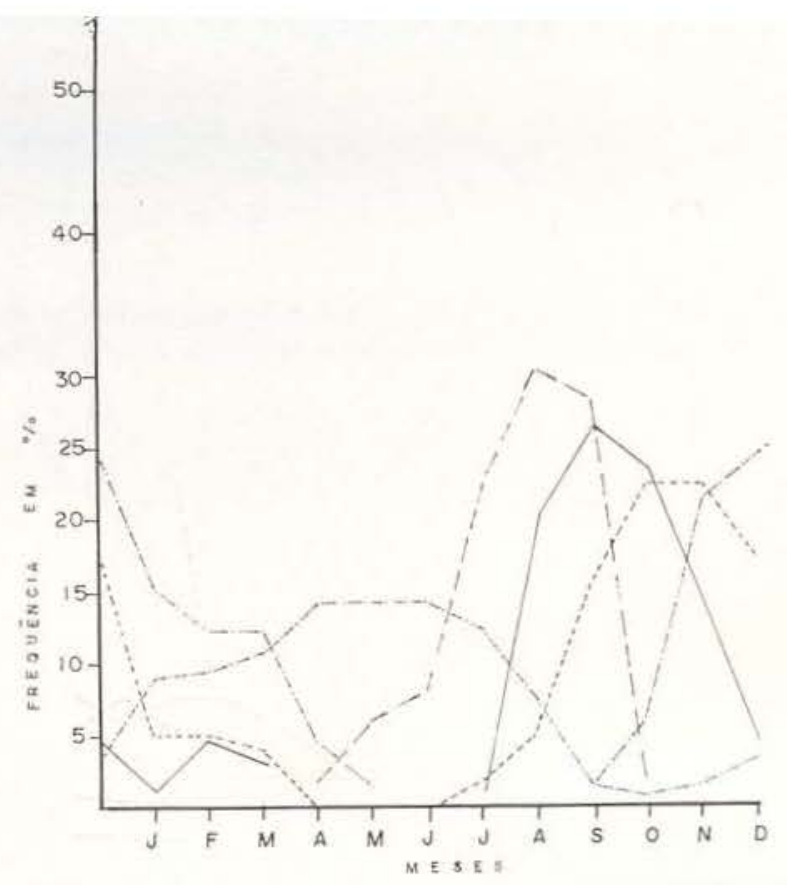

Gráficn 18 - Freqüência no período 1965-1976 em \% VIOLETA (Peltogyne catingae Ducke subsp. glabra (W. Rodr.) M.F. Silva)

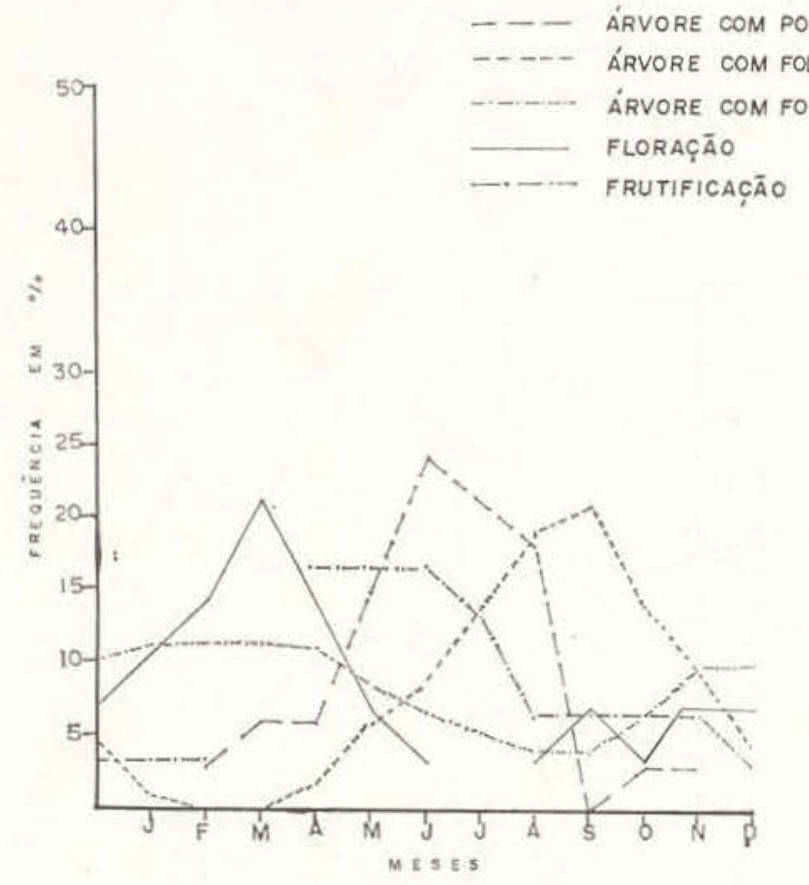

Gráfico 19 - Freqüência no periodo 1955-1976 em \% MULATEIRO (Peltogyne paniculata Eenth subsp. paniculata)

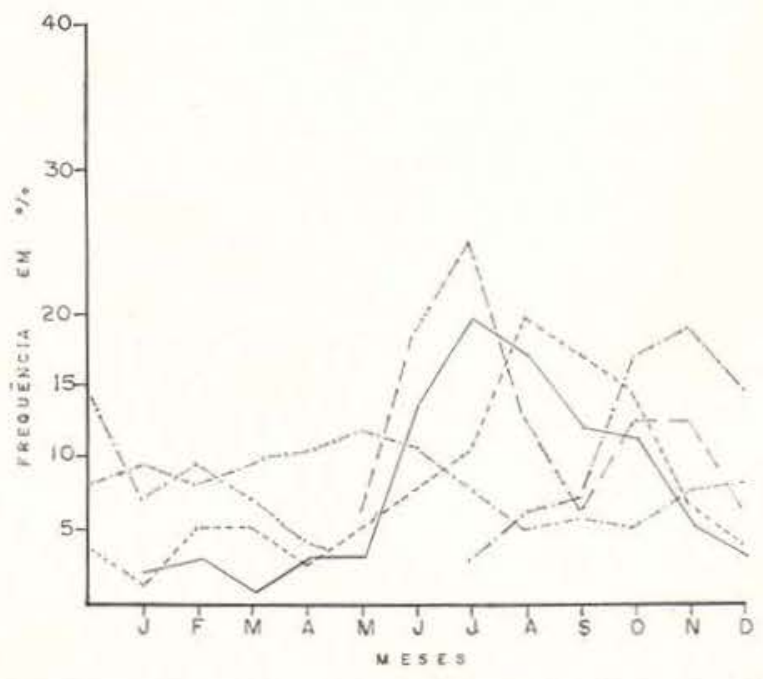

Gráfico 20 - Frequiência no período 1965-1976 em \% ANGELIM-RAJADO (Pitrecolobium racemosum Ducke) 


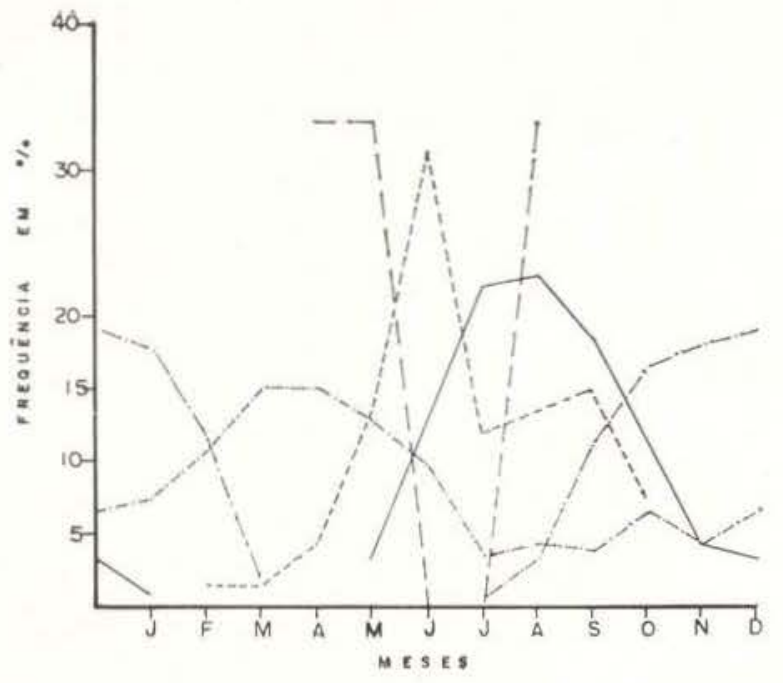

Fráfico 21 - Frequiência no período 1965-1976 em \% CARDEIRO (Scleronema micrantrum Ducke)

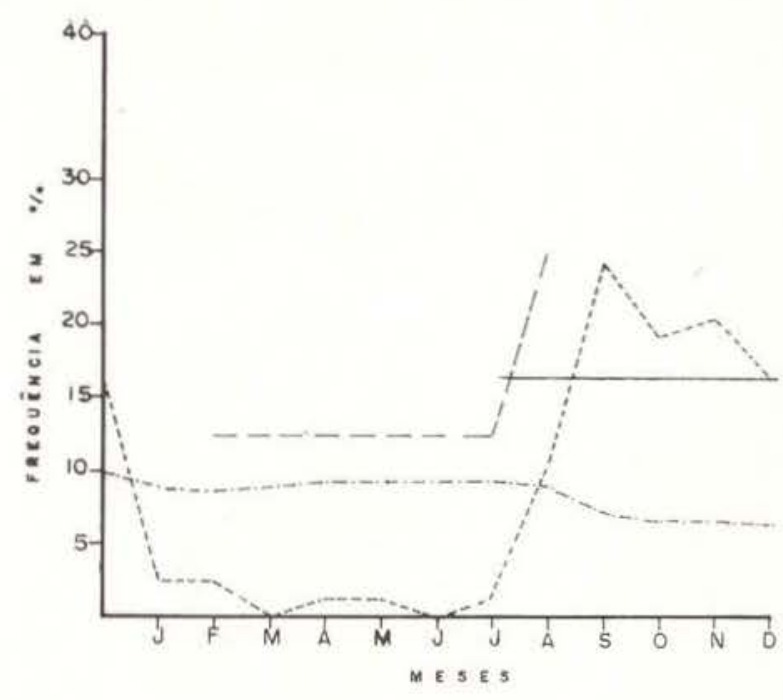

Gráfico 22 - Frequêencia no período 1965-1976 em \% TACHI-PRETO (Tachigalia paniculata Aubl.)

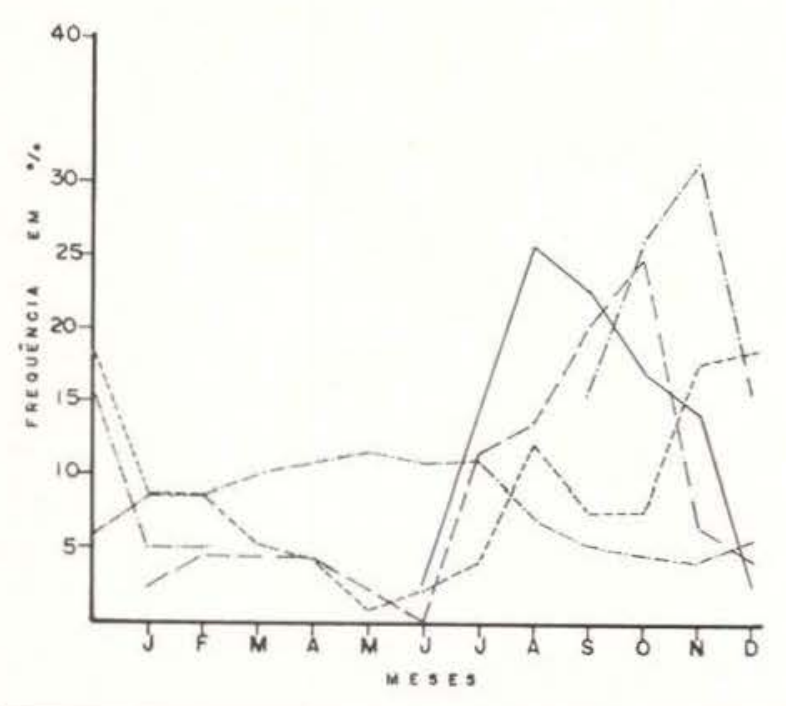

Gráfico 23 - Frequiência no período 1965-1976 em \% PAU-D'ARCO (Tabebuia cf. incana A. Gentry)

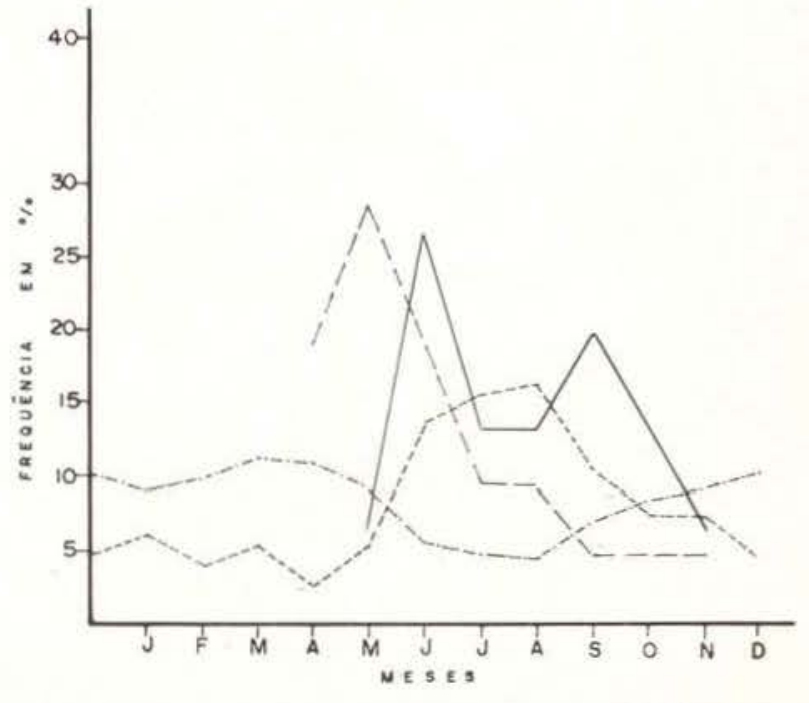

Gráfico 24 - Frequêercia no período 1965-1976 em \% CAJUI (Anacardium spruceanum Benth. ex Engl.)

Fenologia de,... 


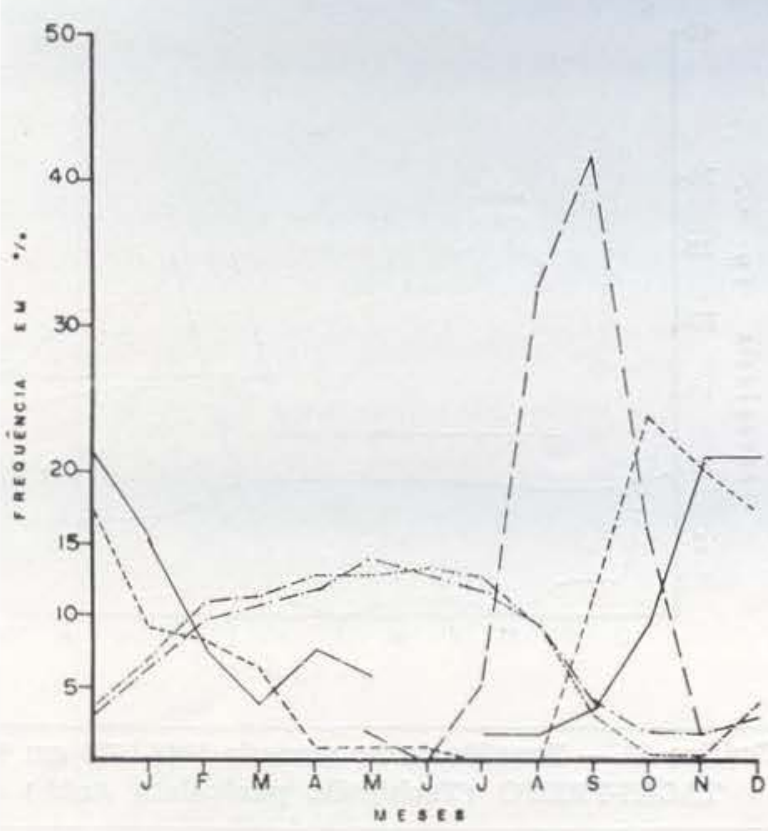

iráfico 25 - Frequiência no período $1965-1976 \mathrm{em} \mathrm{\%}$ CASTANHA-DE-MACACO (Cariniana micrantha Ducke)

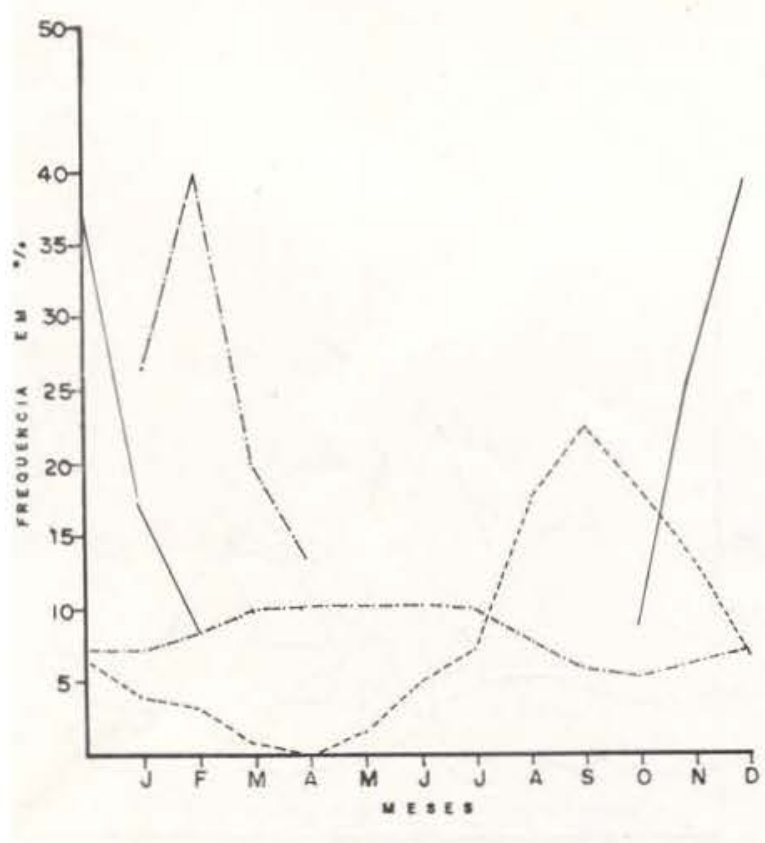

Gráfico 27 - Frequência no período 1965-1976 em \% CEDRORANA (Cedrelinga catenaeformis Ducke)

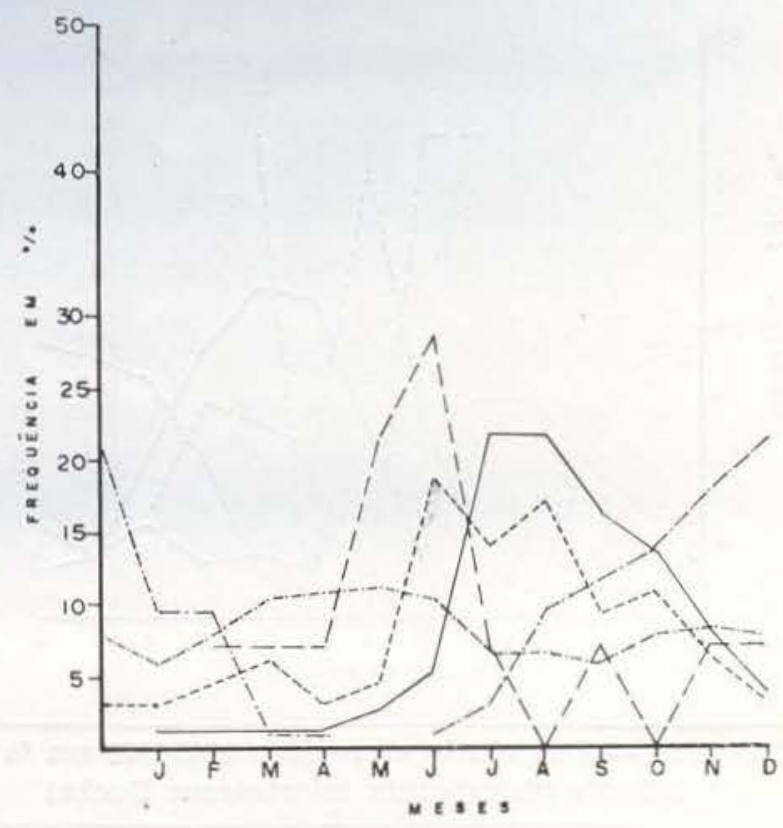

Gráfico 26 - Frequiência no período 1965-1976 em \% MAÇARANDUBA (Manilkara surinamensis (Miq.) Dub.)
- - ARVORE COM POUCA FOLHA OU DESFOLHADA

- - ÁRVORE COM FOLHAS NOVAS

-........ ÁVORE COM FOLHAS VELHA

-. FRUTIFICAÇĀO 
curva da árvore com folhas novas quase sempre seguindo a mesma tendência inicial da floração, antecedendo ou ocorrendo simultaneamente a esia, como no caso da Virola michellii, Erisma fuscum, Mezilaurus synandra, Nectandra rubra, Platymiscium cf. duckei, Jaca. randa copaia, Hevea guianensis, Dipterix odorata, Dinizia excelsa, Couma macrocarpa, Aniba canelilla, Osteophloeum platyspermum, Copaifera multijuga, Scleronema micranthum, Tabebuia cf. incana, Anacardium spruceanum, Cariniana micrantha, Manilkara surinamensis e Cedrelinga catenaeformis; fazem exceção as espécies Vouacapoua pallidior e Peltogyne paniculata, cujo pico de folhas novas ocorre no fim da frutificação; Goupia glabra, Peltogyne catingae e Pithecolobium racemosum, entre a floraçăo e a frutificação; e Calophyllum angulare durante a frutificação.

Quanto à fase "árvore com folhas velhas", verifica-se que $33,33 \%$ das espécies apresentaram-se durante o período de 12 anos com freqüências quase constantes como é o caso de Vouacapoua pallidior, Mezilaurus synandra, Jacaranda copaia, Dipterix odorata, Calophytlum angulare, Andira unifoliolata, Aniba canelilla, Tachigalia paniculata e Cedrelinga catenaeformis.

Com referência à fenofase "árvore com pouca folha ou desfolhada", verifica-se que algumas espécies foram observadas poucas vezes com esta característica. É o caso de Virola michellii observada apenas duas vezes (Set. 75 e Jul. 76); Erisma fuscum, observada em Set. 65, Jul. 67, Ago. 71, Ago. 75, Ago. 76. Aniba canelilla (Jun. 65, Jun. 66, Jun. 68, Jun. 76).

Goupia glabra (Mai. 66, Nov. 74 e Set. Out. 75). Copaifera multijuga (Nov. 65, Out. 68, Set. Out. 74 , Out. 75, Out. 76) .

Calophyllum angulare (Uma vez, Dez. 76).

Scleronema micranthum (Mai. 70, Ago. 75, Abr. 76) .

Cedrelinga catenaeformis (Uma vez, Ago. 75).

O pico da árvore com pouca folha ou desfolhada sempre ocorreu na estação seca ou no final da estação chuvosa para a maioria das espécies. A espécie Osteophloeum platyspermum nunca foi observada desfolhada.
FREQUUÊ̂NCIA ANUAL DO INÍCIO DA FLORAÇÃO E FRUTIFICAÇÃo PARA CADA ESPÉCIE

Nos gráficos 28, 29, 30 e 31 (floração) e $32,33,34$ e 35 (frutificação), são apresentadas as freqüências anuais do início de floração e frutificação para as três repetições de cada espécie, relacionando com os valores da precipitação mensal em milímetros. Vê-se que a maioria dos pontos de ocorrência da floração está distribuída na faixa compreendida entre junho e outubro de cada ano, enquanto que para a frutificação os pontos se distribuem na faixa compreendida entre os meses de setembro e maio.

Verificamos que algumas espécies floraram e frutificaram quase regularmente cada ano, como é o caso de Virola michelii, Osteophloeum platyspermum, Scleronema micranthum, Dinizia excelsa, Couma macrocarpa, Cariniana micrantha, Dipteryx odorata, Hevea surinamensis e Goupia glabra.

Outras floraram e frutificaram com intervalos de dois anos: Vouacapoua pallidior. Nectandra rubra, Jacaranda copaia, Calophyllum angulare $(65,67,69,71$, depois florou irregularmente), Copaifera multijuga, Pithecolobium racemosum $(65,67,69,71$, depois florou regularmente até 76) e Manilkara surinamensis (a partir de 70 , florou e frutificou regularmente cada ano); algumas espécies apresentaram floração e frutificação irregulares: Erisma fus* cum, Mezilaurus synandra, Platymiscium cf. duckei, Andira unifoliolata, Aniba canelilla, Anacardium spruceanum, Tabebuia cf. incana, Peltogyne paniculata, Peltogyne catingae e Cedrelinga catenaeformis (entre 72 e 76 florou e frutificou regularmente cada ano); e espécie que florou e frutificou apenas duas vezes, em 12 anos, de observação (65 e 69): Tachigalia paniculata.

Observa-se também que várias espécies apresentaram o fenômeno de floração duas vezes no mesmo ano com Dipteryx odorata (68 e 70), Tabebuia cf. incana (68), Virola michelii (72), Hevea surinamensis (71), Couma macrocarpa (73), Goupia glabra (73 e 75) e Peltogyne catingae (74); e espécies que apresentaram duas frutificações no mesmo ano: Hevea guia- 


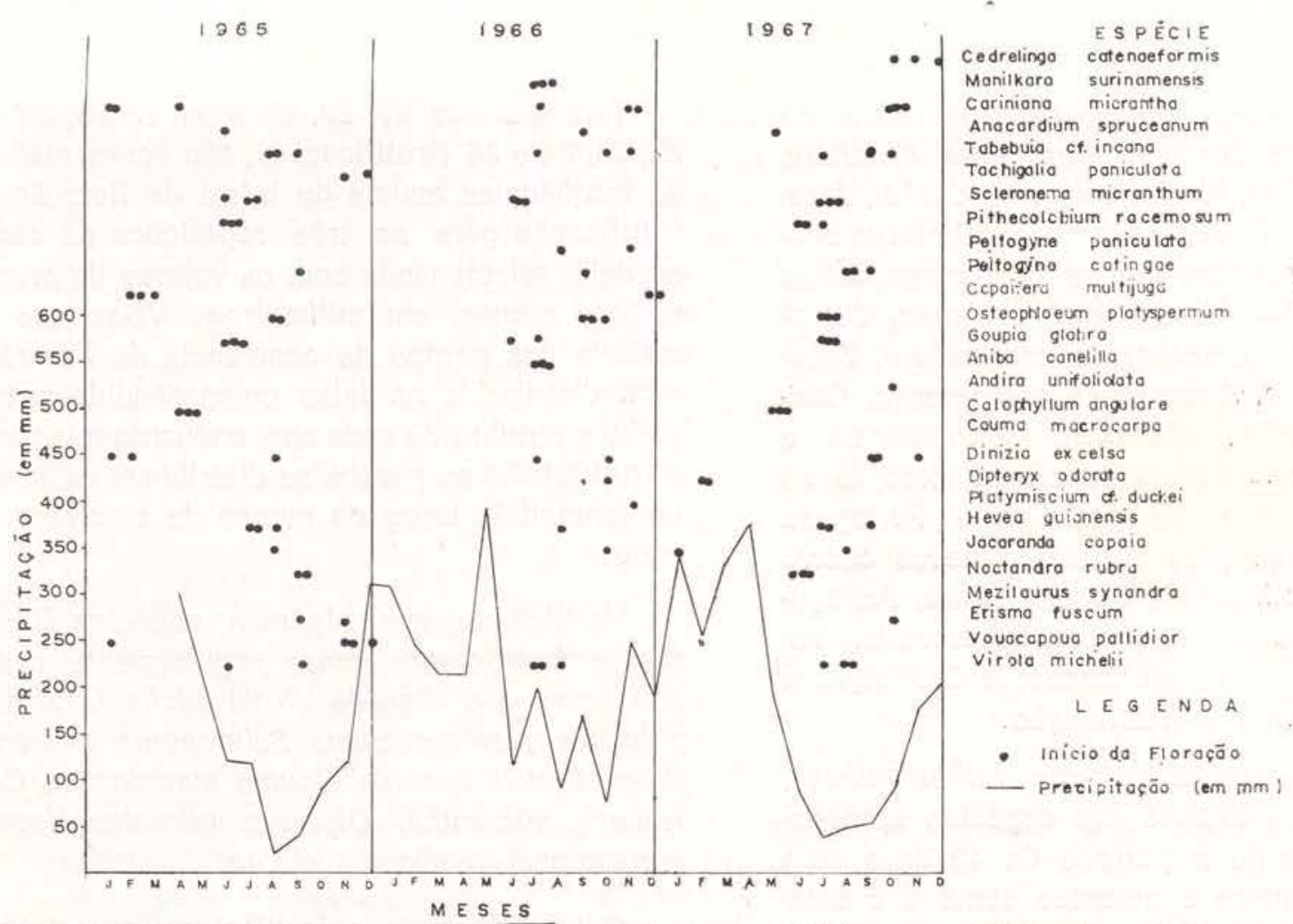

Gráfico 28 - Frequêência anual do início da floração no período 1965 - 1976

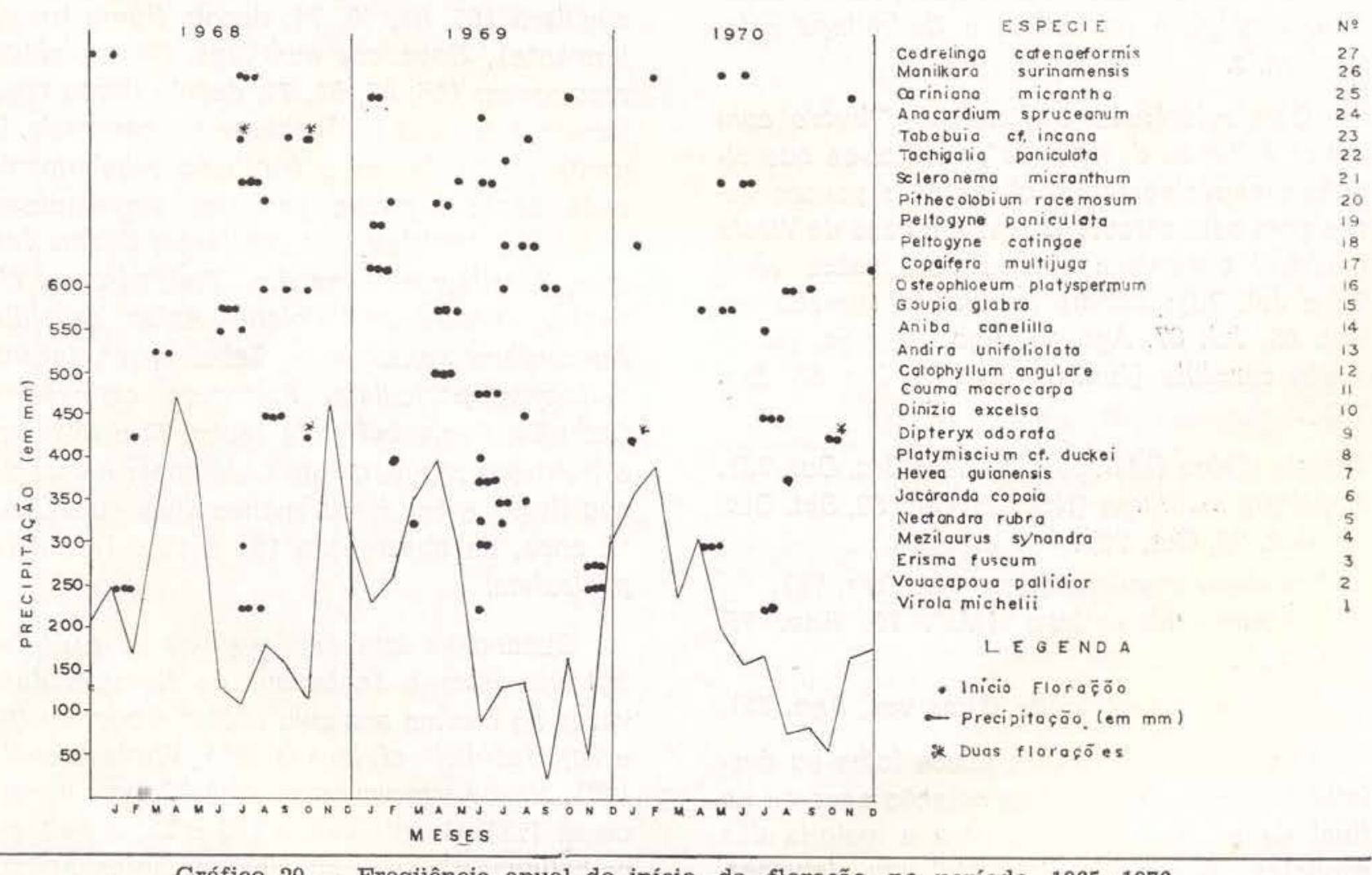

Gráfico 29 - Frequêencia anual do início da floração no período 1965-1976 


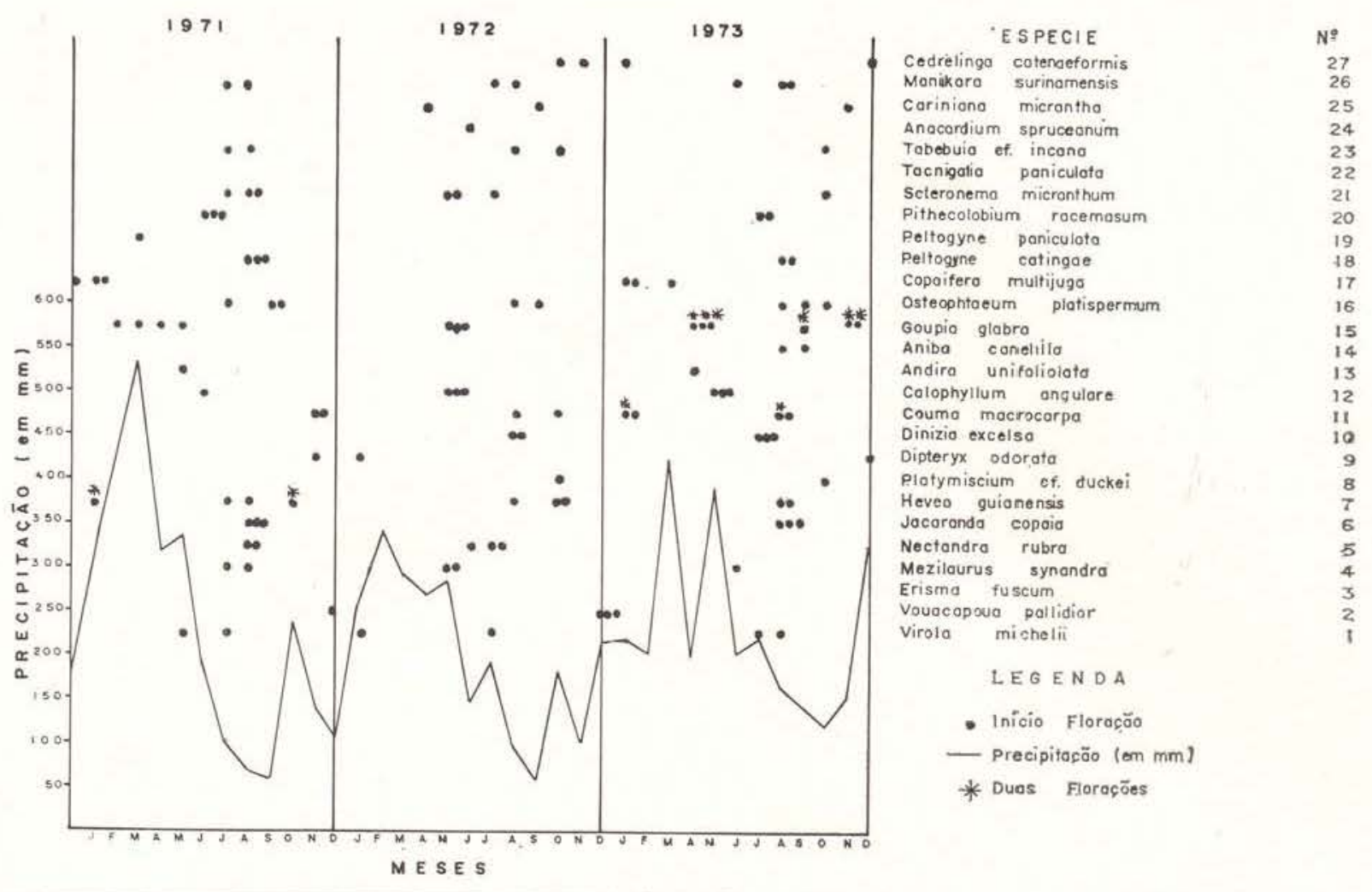

Gráfico 30 - Freqüência anual do início da floração no período 1965 - 1976

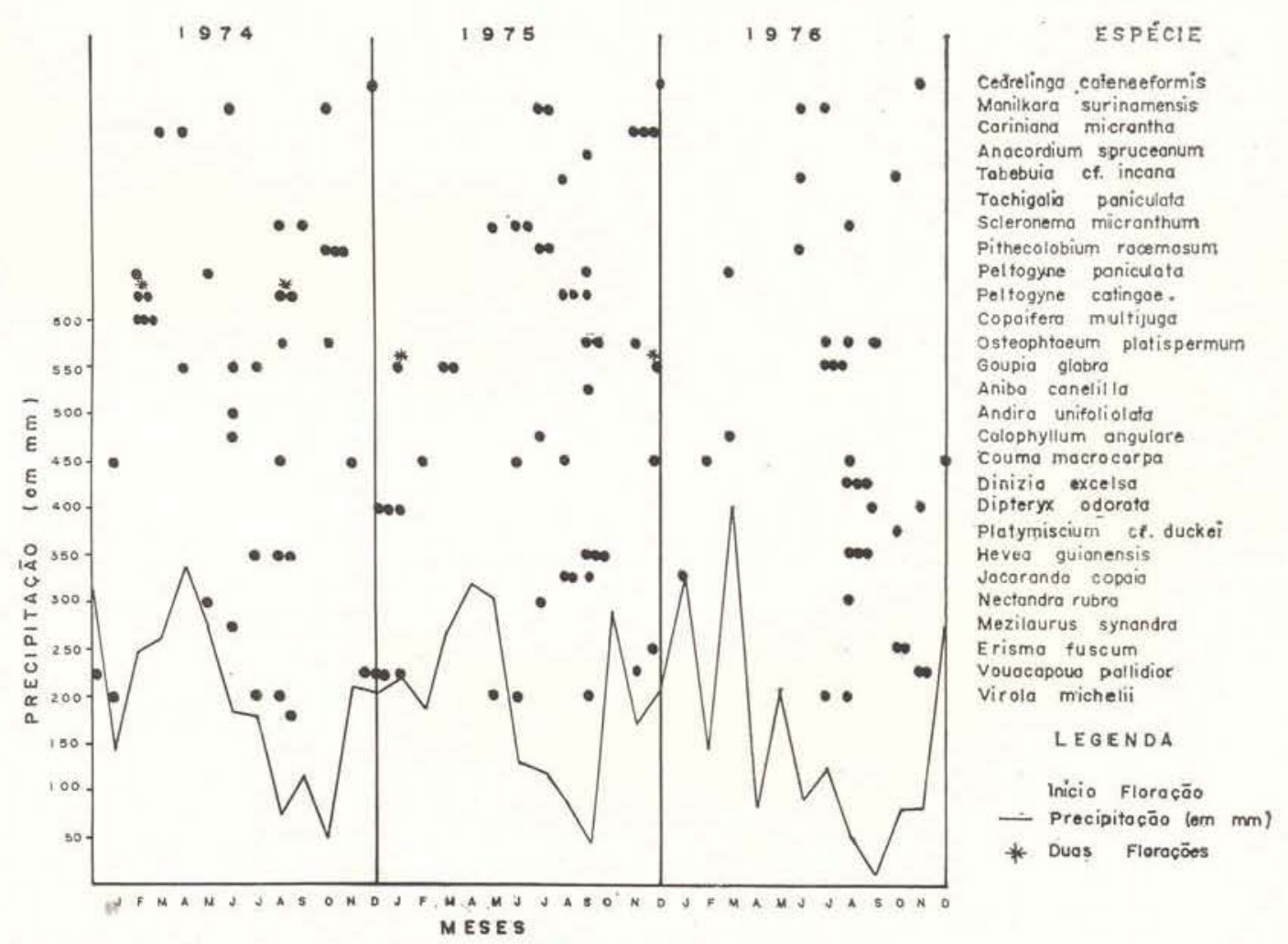

Gráfico 31 - Frequêencia anual do início da floração no período 1965 - 1976 


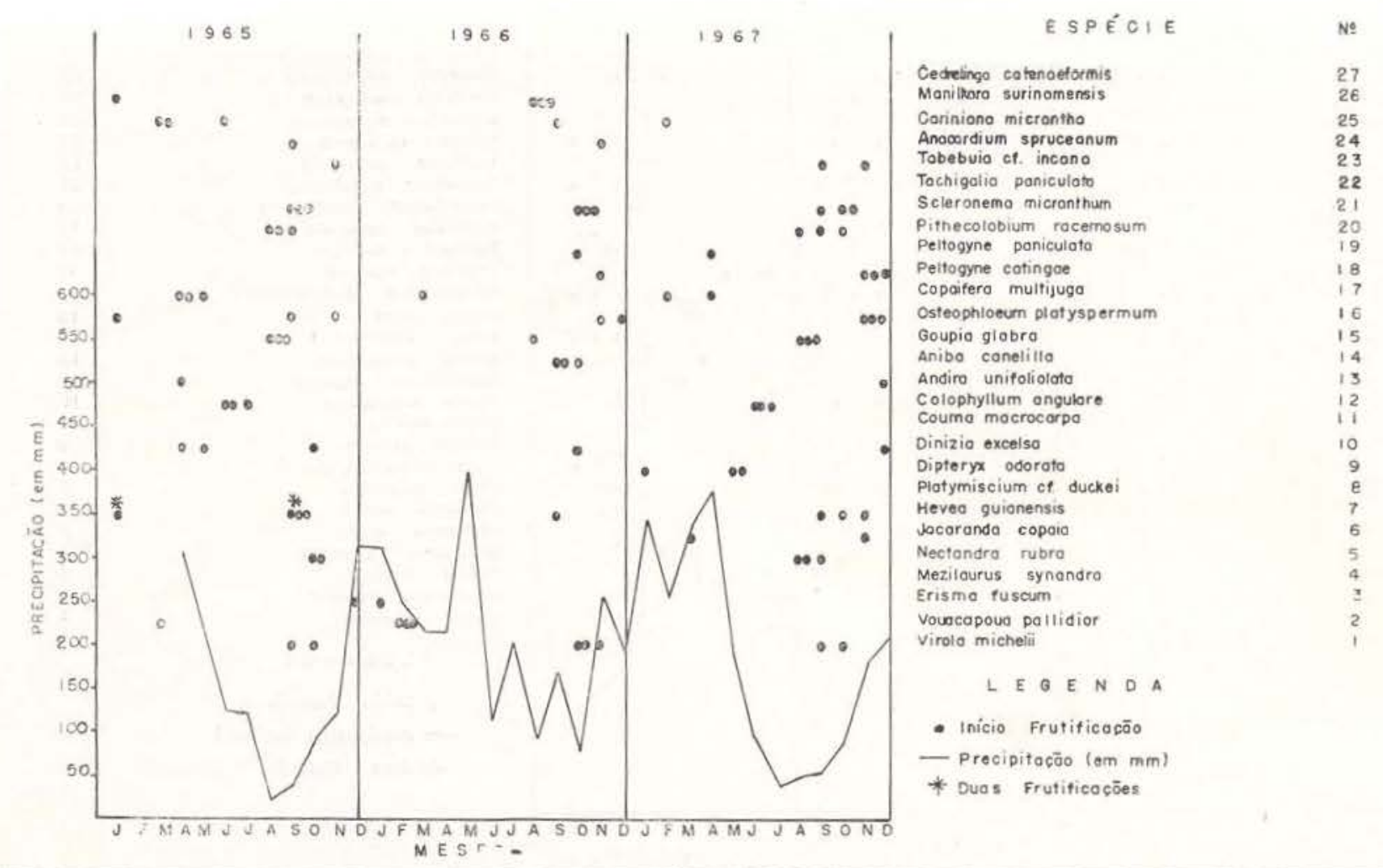

Gráfico $32-$ Frequiência anual do início da frutificação no período 1965 - 1976

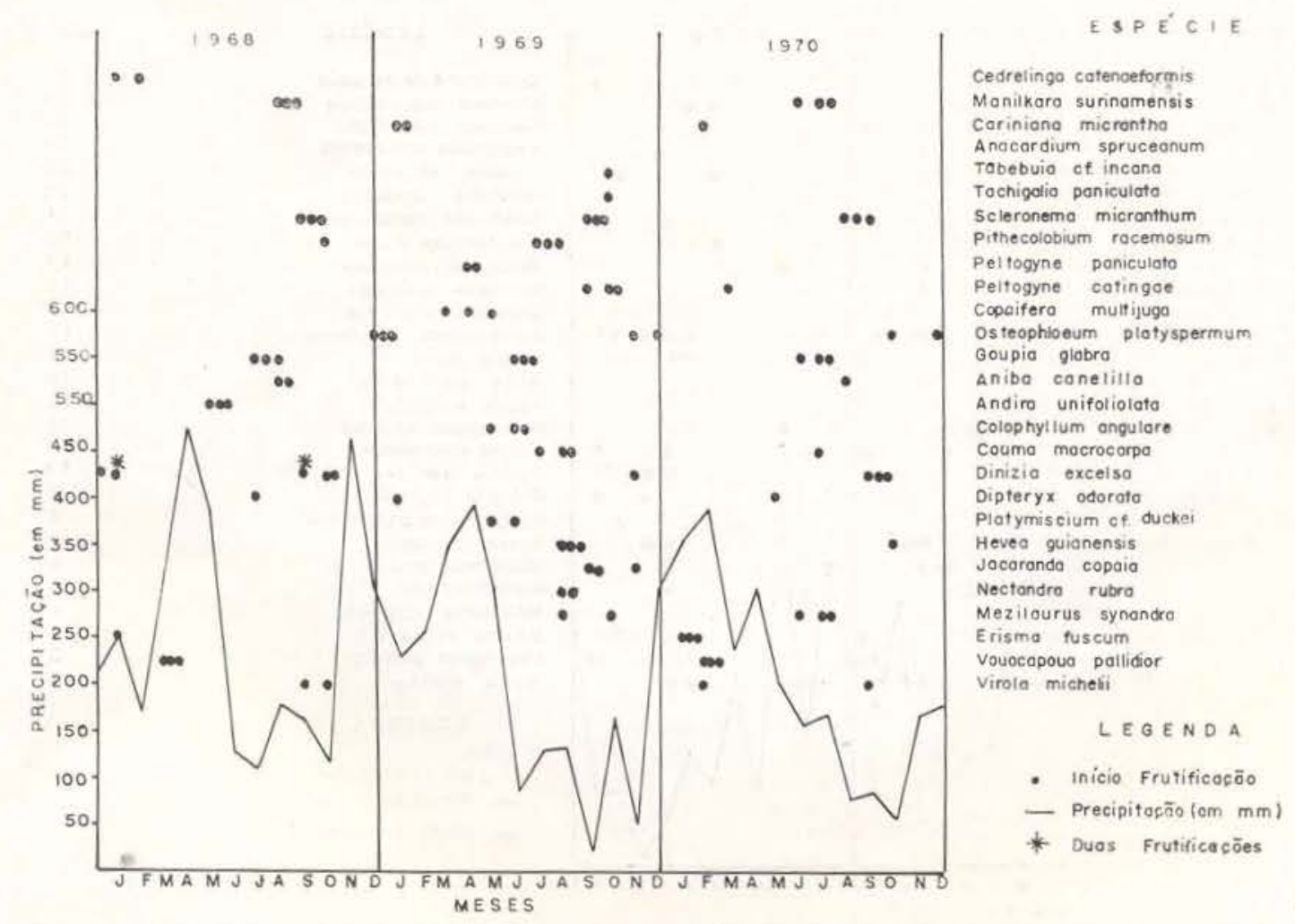

Gráfico 33 - Frequêencia anual do início da frutificação no período 1965-1976 


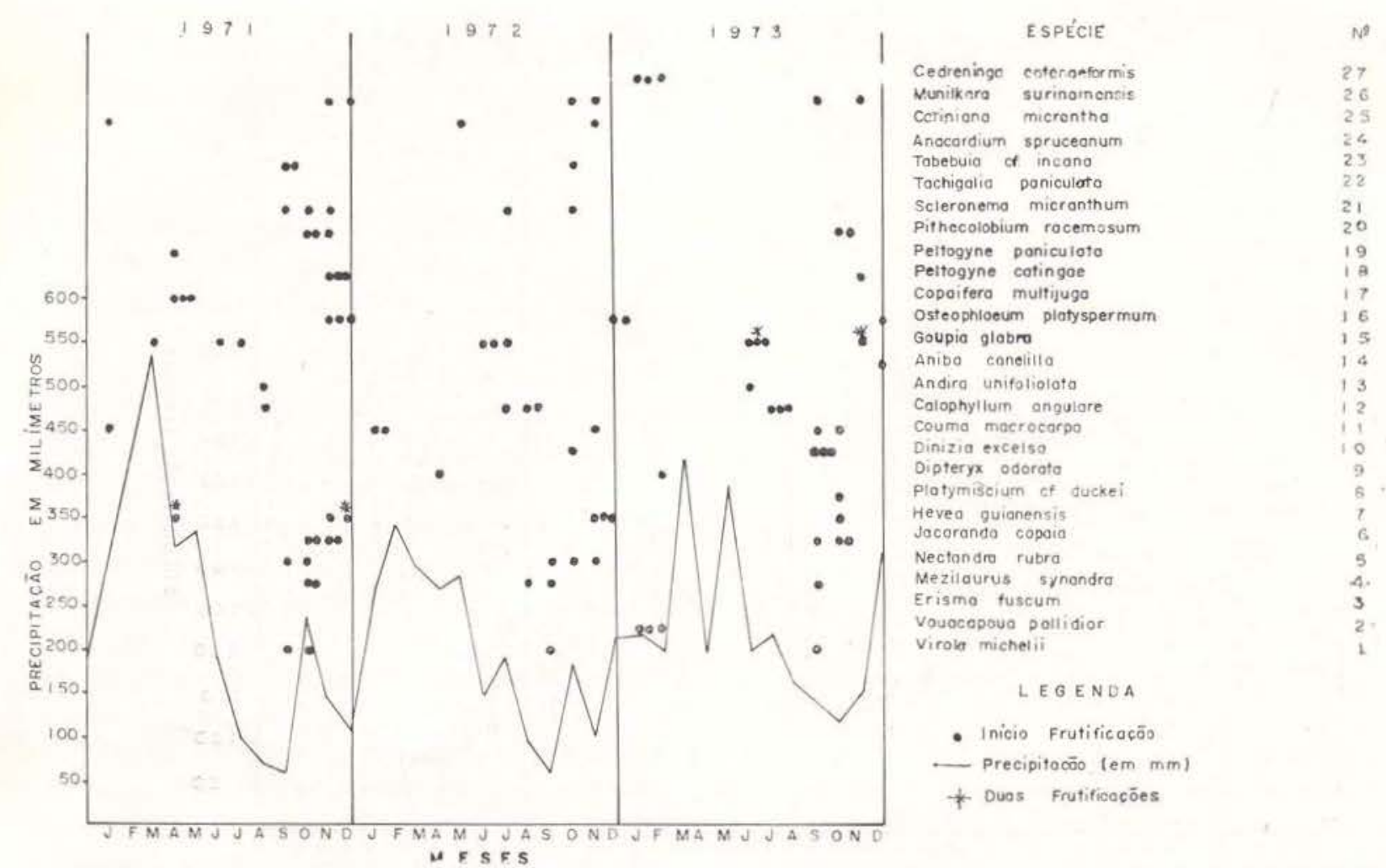

Gráfico 34 - Frequiência anual do início da frutificação no período 1965-1976

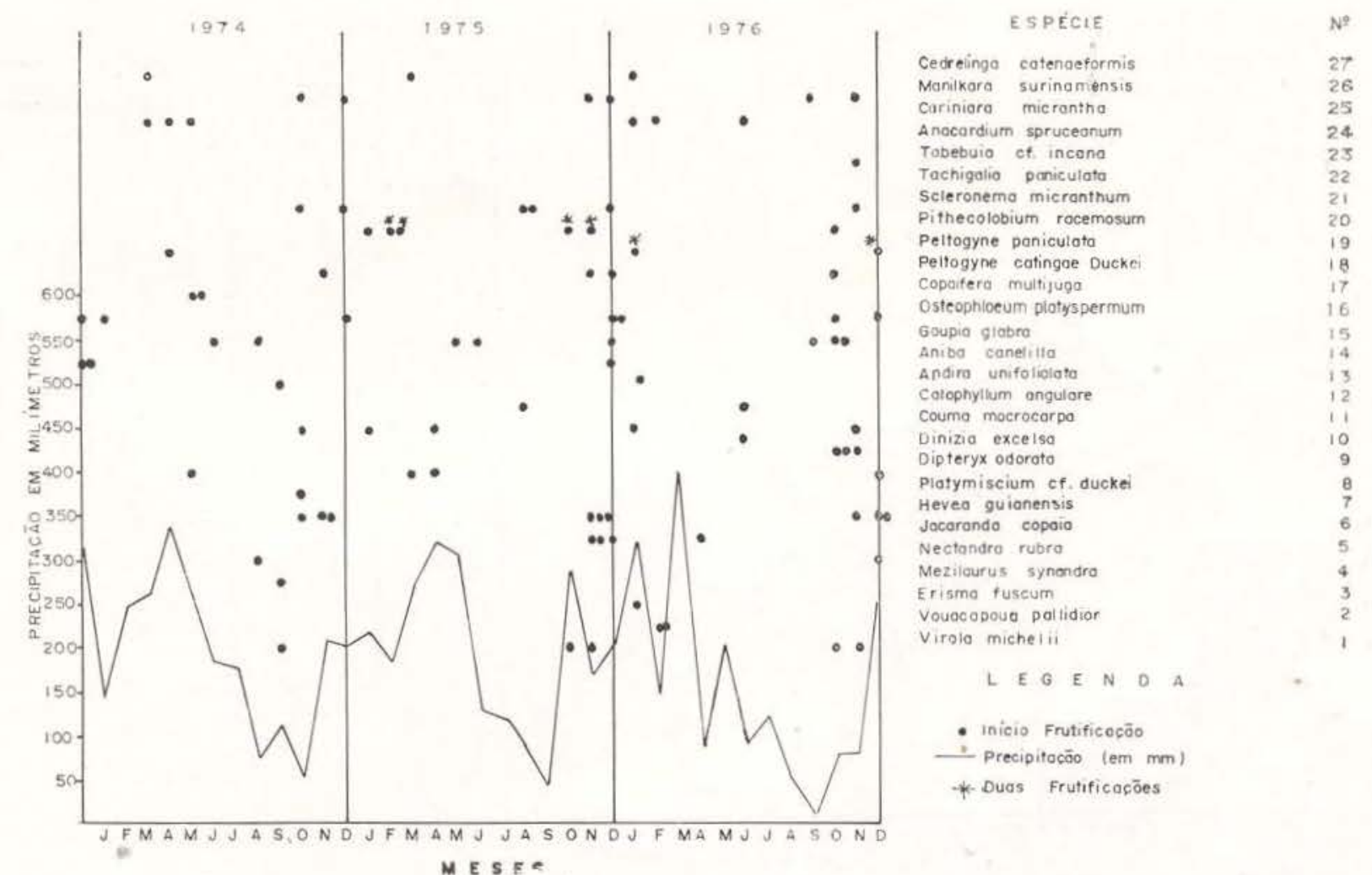

Gráfico 35 - Frequiência anual do início da frutificação no período 1965 - 1976

Fenologia de... 


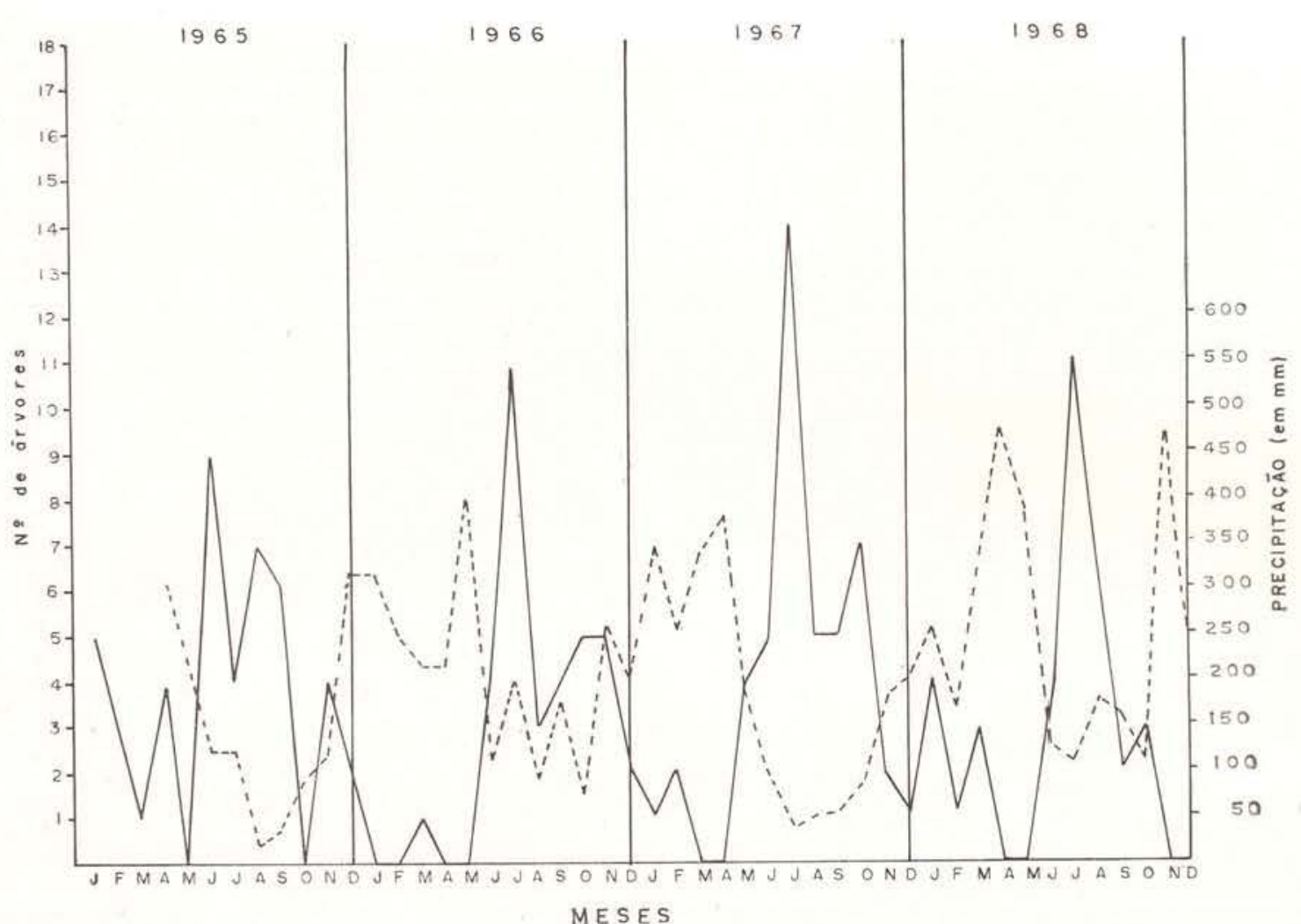

Gráfico 32 - Frequiência anual do início da frutificação no período 1965 - 1976

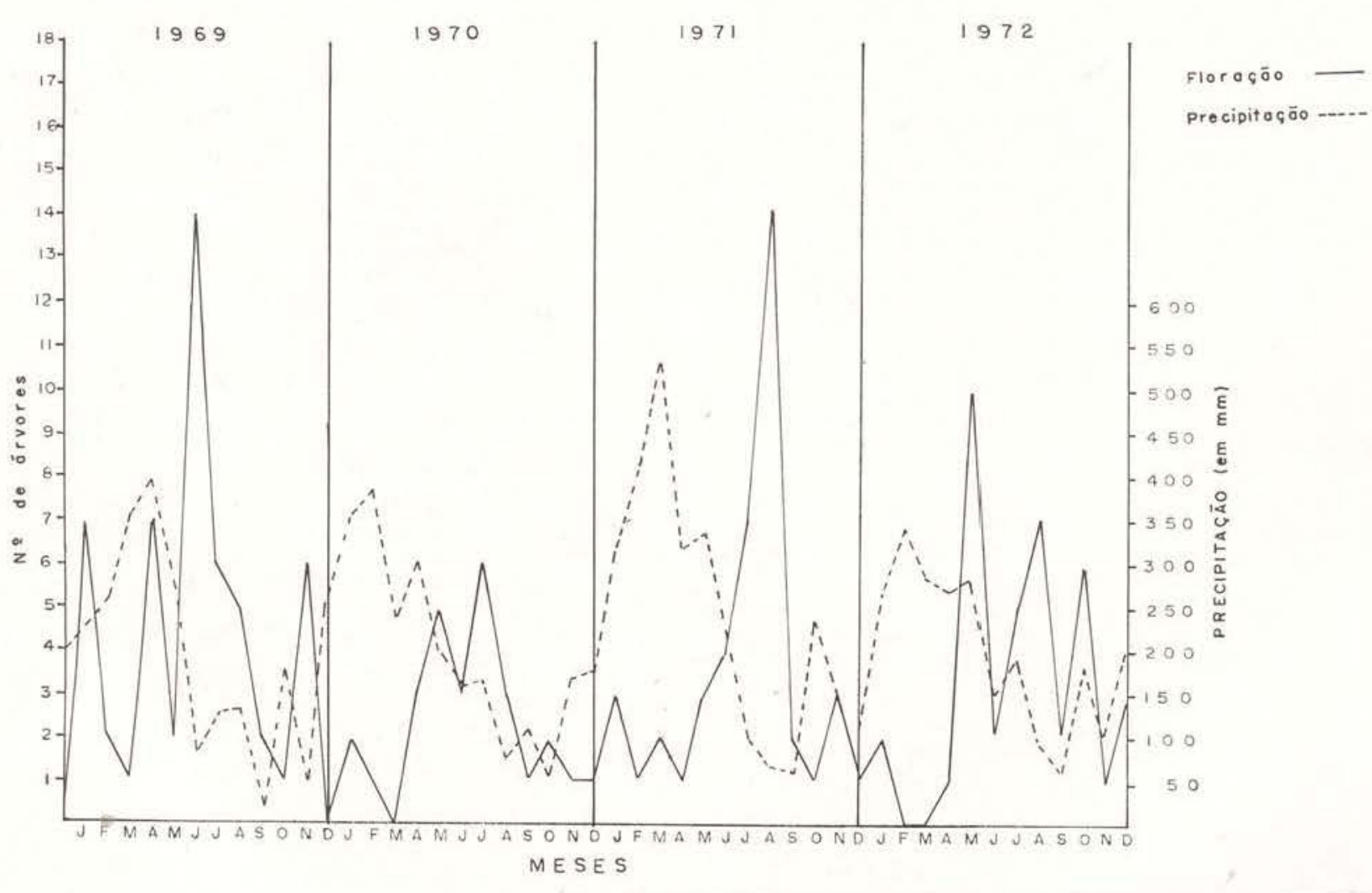

Gráfico 33 - Frequiência anual do início da frutificação no período 1965-1976 
nensis (65 e 71), Dinizia excelsa (68), Goupia glabra (73), Peltogyne paniculata (76) e Pithecolobium racemosum (75).

PERIODICIDADE DO INÍCIO DA FLORAÇÃO E FRUTIFICAÇÃO PARA AS ESPÉCIES CONSIDERADAS EM CONJUNTO

Pelos gráficos $36,37,38$ (floração) e 39 , 40, 41 (frutificação), vê-se que há uma certa pericdicidade para o início da floração e frutificação para as espécies estudadas. Assim, durante o período de 12 anos, o início da floração apresentou um pico quase constante, entre os meses de junho ( 65 e 69), julho (66, $67,68,70)$, agosto $(71,73,74$ e 76$)$, setembro (75), exatamente os meses que caracterizam a estação seca, com os menores valores de precipitação conforme mostram os gráficos. Quanto ao início da frutificação, os gráficos apresentaram um pico em agosto $(68,69)$, setembro ( 65 e 73 ), outubro $(66,74$ e 76$)$, no- vembro $(67,71,72$ e 75). A maturação dos frutos e disseminação das sementes ocorreram para a maioria das espécies no período chuvoso (Veja gráfico 1 a 27) .

PERIODICIDADE DO INÍCIO DA FLORAÇÃO E FRUTIFICAÇÃo EM DOIS ESTRATOS DA FLORESTA

Verifica-se, pelos gráficos 42 e 43 , que o número total de árvores em início de floração e frutificação, foi maior no dossel da mata do que no dossel inferior, mostrando que a posição da árvore é fator importante na floração e conseqüente frutificação (Gráficos 42 e 43).

$\mathrm{O}$ teste não paramétrico $\mathrm{H}$ de Kruskal Wallis, apresentou os valores de $\mathrm{H}=15,514$ para a floração e 23,842 para a frutificação. O valor de $x^{2}$ para 0,005 de probabilidade e 1 grau de liberdade é 7,879 , inferior aos valores de $\mathrm{H}$ calculados. Por isto, a hipótese nula é

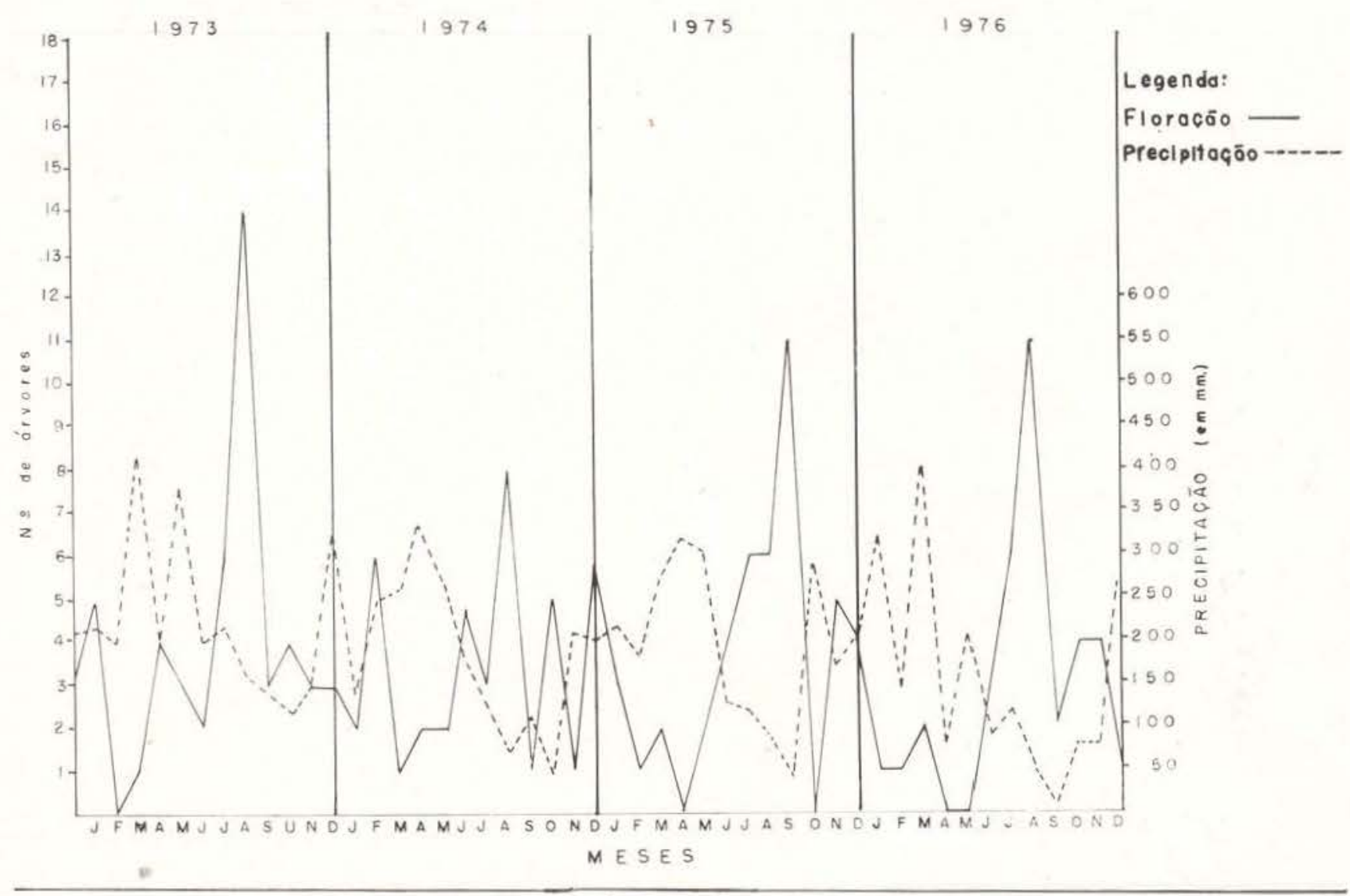

Gráfico 38 - Periodicidade do início da floração de 81 árvores 


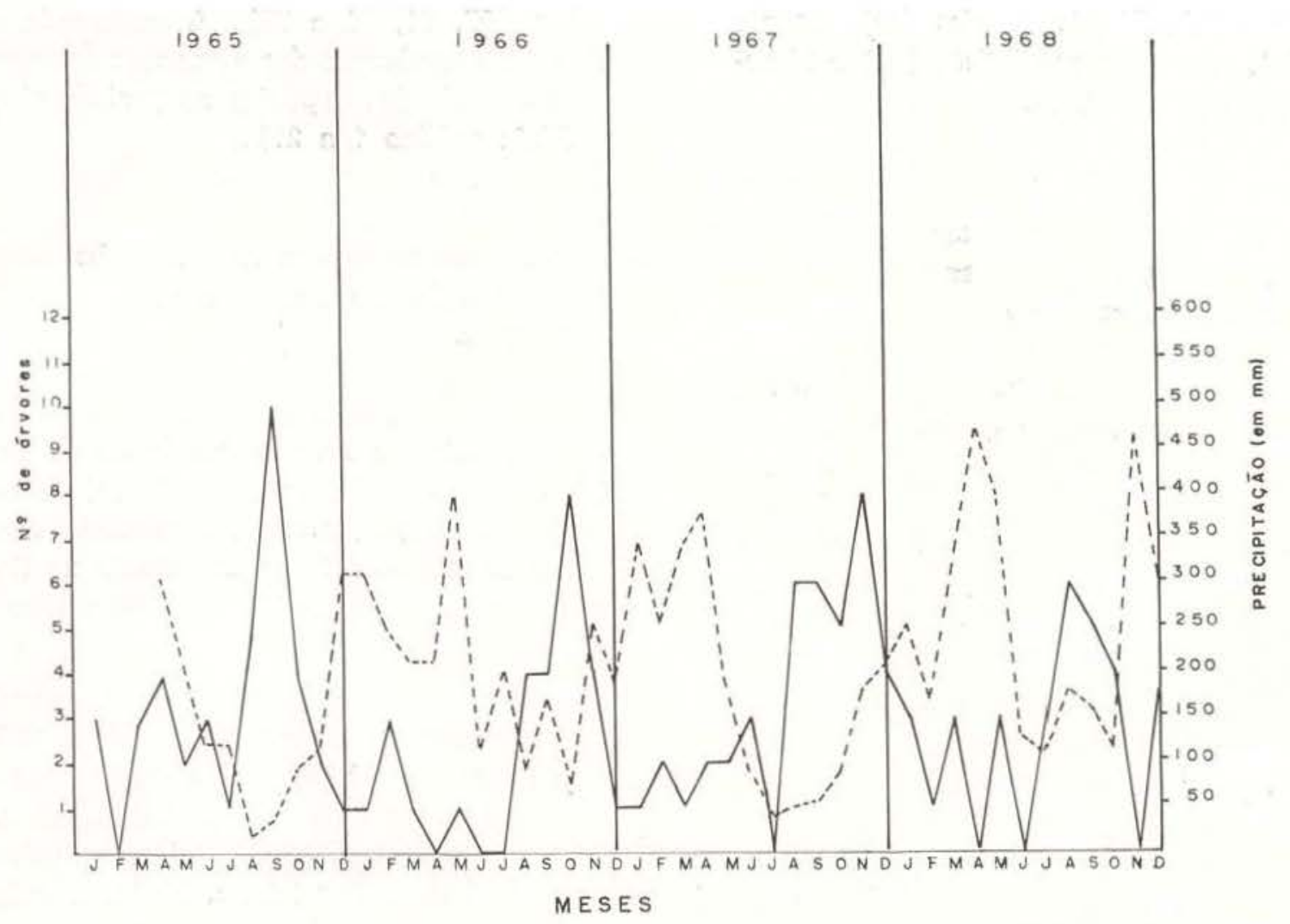

Gráfico 28 - Frequêencia anual do início da floração no período 1965 - 1976

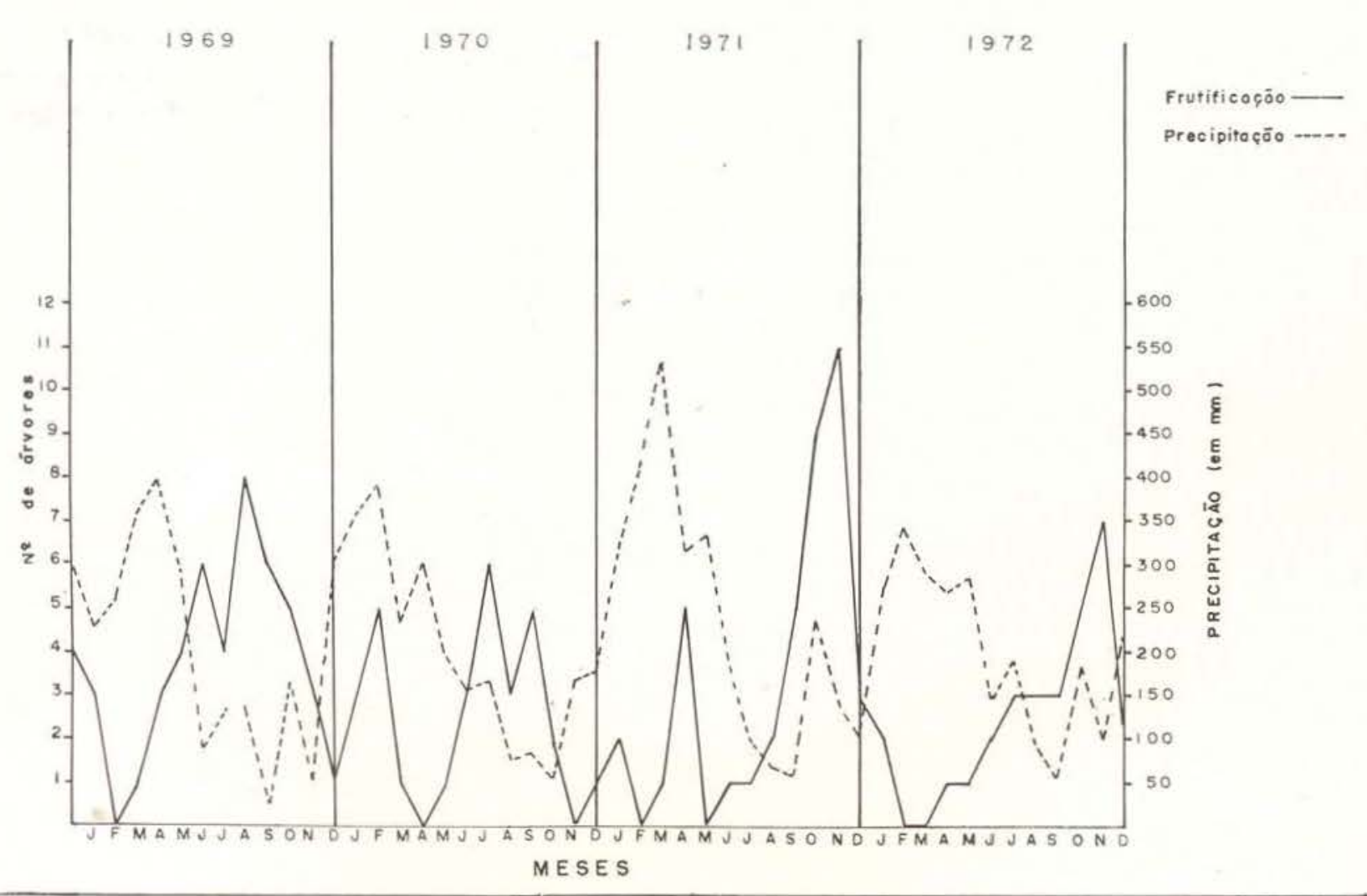

Gráfico 29 - Frequiência snual do início da floração no período 1965 - 1976 
rejeitada, isto é, as duas amostras (dossel e dossel inferior) variam significativamente ao nível de probabilidade considerado, e podemos afirmar que elas pertencem a populações diferentes, tanto na floração como na frutificação.

\section{DURAÇÃO DA FLORAÇÃo E FRUTIFICAÇÃo POR ESPÉCIE}

Nas tabelas ( 3 e 4 ), apresentamos a duração das duas fenofases, em meses. Vê-se que o intervalo observado para a floração varia de 1 a 7 meses para as 27 espécies estudadas, sendio que a duração mais freqüente, durante os 12 anos, foi de 3 meses. Para a frutificação, o intervalo observado variou de 1 a 9 meses, sendo a duração de 5 meses a mais freqüente durante o período de 12 anos. Com base nesses resultados e nas freqüências relativas e em porcentagens, para o intervalo de 1 a 8 meses, nas duas fenofases, concluimos (Tabela 5) que $88,89 \%$ das 27 espécies estudadas apresentaram uma duração entre 2 a 4 meses para floração completa e a maior freqüência de $48,15 \%$ ocorreu quando a duração foi de $3 \mathrm{me}$ ses. Quanto a frutificação, a maior freqüência de $33,34 \%$ ocorreu para a duração de 5 meses.

Com isto, concluímos que a duração da frutificação foi sempre mais longa do que a da floração.

TEMPO DE VIDA DAS FOLHAS E TIPOS DE MUDANÇA FOLIAR

$\mathrm{Na}$ tabela 6, estão apresentados os resultados para cada espécie, onde verificamos que o tempo de vida das folhas não é regular, tendo variado de 4 a 25 meses para as 27 espécies estudadas, do seguinte modo: $51,85 \%$ apresentaram o tempo de vida entre $(4-15)$ meses; $33,33 \%$ entre $(4-22)$ meses; $7,41 \%$ entre $(10-16)$ meses e $7,41 \%$ entre $(4-25)$ meses. Quanto aos tipos de mudança foliar, 16 espécies foram classificadas como perenifólias, sendo este o tipo mais freqüente; a seguir, 8 espécies como semi-caducifólias e 3 como caducifólias.

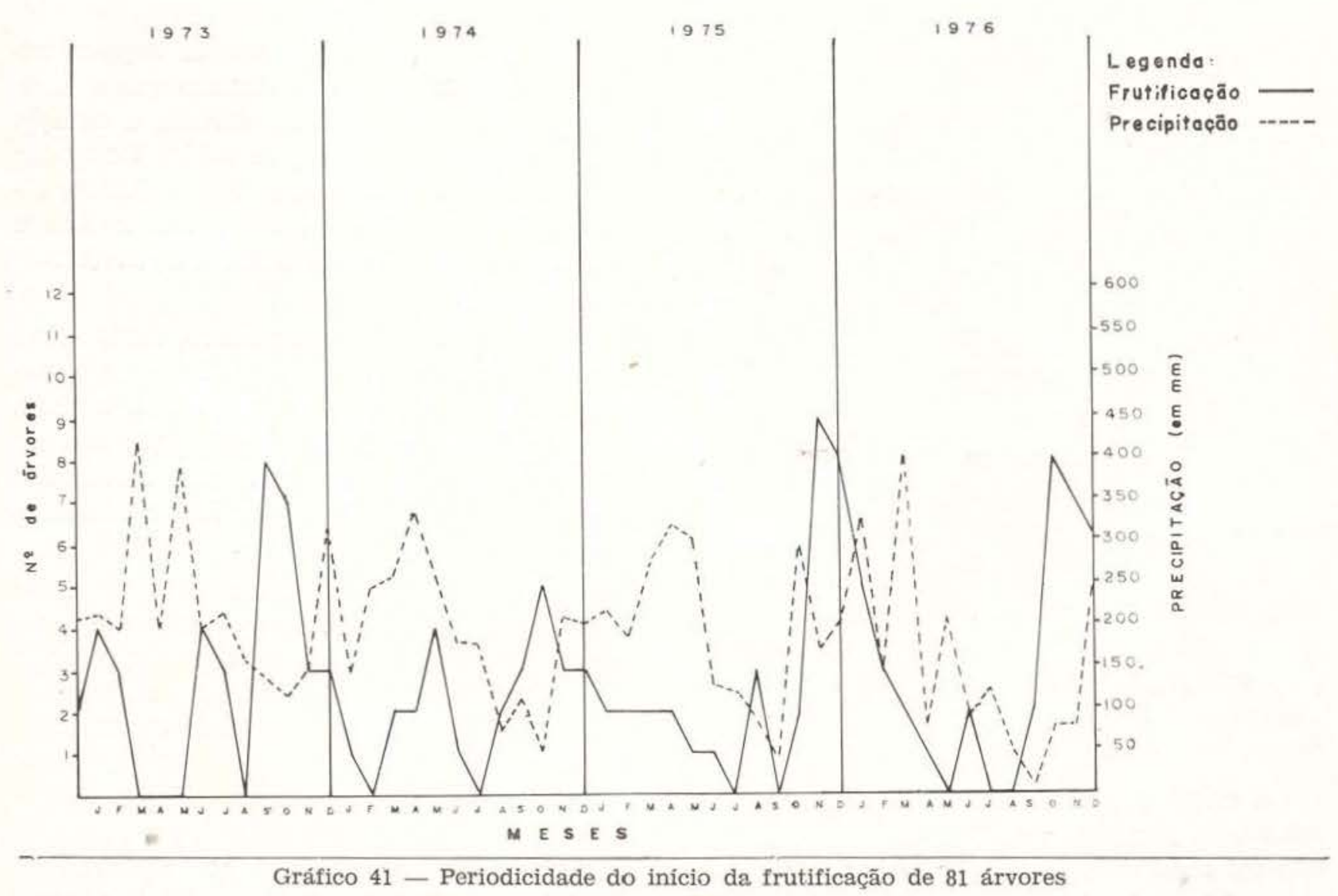




\section{ANÁLISE DE REGRESSÃO SIMPLES}

Apresentamos os resultados da análise de regressão simples entre o número de árvores que começaram a florar (gráficos 36,37 e 38) e frutificar (gráficos 39,40 e 41 ) e os valores da precipitação, umidade relativa e temperatura máxima absoluta, para o período de 1965 a 1976.

Floração e Precipitação em milimetros : $\mathrm{Y}=252,5575-15,1024 \mathrm{X}$; Erro padrão de $\mathrm{B}=$ 2,$6391 ; \mathrm{t}$ (student) $=-5,723 * * *(0,1 \% \mathrm{e}$ 142 graus de liberdade; $P<0,0001$ ); Coeficiente de correlação $r=-0,4329$.

Floração e Umidade Relativa em \% : $\mathrm{Y}=$ 90,3793 - 0,3129X; Erro padrão de $B=$ 0,$1132 ; \mathrm{t}$ (student) $=-2,765 \cdots(1 \%$ e 142 graus de liberdade; $P=0,0065) ; r=-0,2260$.

Floraçăo e temperatura máxima absoluta : $\mathrm{Y}=32,8958+0,0608 \mathrm{X}$; Erro padrão de $\mathrm{B}=$ 0,$0435 ; \mathrm{t}$ (student) $=1,397 \mathrm{~N} / \mathrm{S}(\mathrm{P}=0,161)$; $r=0,1165$.

Frutificação e Precipitação em milimetros : $Y=242,5845-14,6908 X ;$ Erro padrão de $\mathrm{B}=3,5415 ; \mathrm{t}$ (student) $=-4,148 * *$ *; $(0,1 \%$ e 142 graus de liberdade; $P=0,0002)$; $r=-0,3288$.

Frutificação e Umidade relativa em \% : $\mathrm{Y}=91,0810-0,6258 \mathrm{X} ;$ Erro padrão de $\mathrm{B}=$ 0,$1393 ; \mathrm{t}$ (student) $=-4,494^{* * *} ;(0,1 \% \mathrm{e}$ 142 graus de liberdade; $P=0,0001) ; r=-$ 0,3528 .

Frutificação e temperatura máxima absoluta: $Y=32,4590+0,2279 x$; Erro padrão de $\mathrm{B}=0,0528 ; \mathrm{t}$ (student) $=4,318 \cdots * ;(0,1 \%$ e 142 graus de liberdade; $P=0,0001) ; r=$ 0,3407 .

Os resultados da análise de regressão simples entre o início da floração e a precipitação, demonstram que, para menores valores de precipitação, a tendência é serem observados maiores valores de floração, como ocorreu para a maioria das espécies estudadas.

A correlação entre a floração e a umidade relativa \% também é do típo linear negativa. Não foi observada correlação com a temperatura máxima absoluta.
Os resultados para o início da frutificação mostraram a mesma tendência da floração, com relação à precipitação e umidade relativa. A correlação entre frutificaçâo e temperatura máxima absoluta foi do tipo linear positiva.

\section{CARACTERÍSTICAS DAS ÁRVORES OBSERVADAS}

As características dendrológicas e botânicas estão discriminadas na tabela 7 (Veja figuras 1,2 e 3 ).

\section{DISCUSSÕES E CONCLUSÕES DOS RESULTADOS}

Conforme expusemos, a maioria das espécies estudadas $(62,96 \%)$ floresceu durante a estação seca e o pico do início da floraçăo para as espécies consideradas em conjunto ocorreu sempre entre junho a setembro, conforme mostram os gráficos 36,37 e 38 . A análise de regressão com a precipitação mostrou que houve uma tendência de se encontrar um maior número de árvores iniciando a florar quando ocorreram menores valores de precipitação.

Vários pesquisadores noutras regiões tropicais do mundo relatam também que a floração ocorre principalmente durante a estação seca (Aubréville (1938), na África Ocidental; Holttum (1953), Singapura; Njoku (1963), Nigéria; Ducke \& Black (1953), Brasil; Araujo (1970), Brasil; e Frankie, Baker \& Opler (1974), Costa Rica) .

Walter (1964, em Daubenmire, 1972) relata essa mesma ccorrência nas florestas semidecíduas. Daubenmire (1972) afirma também que, na Costa Rica, o pico da floração sempre aparece 2 meses antes da chegada normal das chuvas, com a produção de folhas não atingindo seu pico até que as chuvas comecem.

Verificamos que algumas espécies floraram e frutificaram quase regularmente cada ano. A floração com periodicidade regular já foi observada também em muitas florestas tropicais (Bews, 1927; Ashton, 1969; Croat, 1969; Holttum, 1953; Richards, 1952; Medway, 1972; Rees, 1964; e Frankie, Baker \& Opler, 1974). Outras floraram e frutificaram com intervalos de dois anos. Outras espécies apresentaram floração e frutificação irregulares. E a espé- 
cie que florou e frutificou apenas duas vezes em 12 anos de observação $(65-69)$ : Tachigalia paniculata. Verificamos também que vá. rias espécies floraram e frutificaram duas vezes ao ano.

Observamos na Reserva Ducke que as chuvas após um período de seca exerceram uma função importante, provavelmente estimulando a floração, e que $70,37 \%$ das espécies apresentaram folhas novas antes ou simultaneamente com a floração.

TABELA 1 - Classificação das espécies em grupos por períodos de ocorrência da floração.

\begin{tabular}{|c|c|c|}
\hline Grupo & Época & $\begin{array}{c}\text { Espécies } \\
\text { (Nome científico) }\end{array}$ \\
\hline 1 & Jan. Abr. & $\begin{array}{l}\text { Peltogyne paniculata } \\
\text { Cepaifera multijuga }\end{array}$ \\
\hline 2 & Mar. Jun. & Andira unifoliolata \\
\hline 3 & Abr. Ago. & $\begin{array}{l}\text { Calophyllum angulare } \\
\text { Goupia glabra } \\
\text { Mezilaurus synandra }\end{array}$ \\
\hline 4 & Jul, Out. & $\begin{array}{l}\text { Virola michelii } \\
\text { Couma macrocarpa } \\
\text { Aniba canelilla } \\
\text { Tabebuia cf. incana } \\
\text { Nectandra rubra } \\
\text { Pithecolobium racemosum } \\
\text { Scleronema micranthum } \\
\text { Anacardium spruceanum } \\
\text { Tachigalia paniculata } \\
\text { Manilkara surinamensis }\end{array}$ \\
\hline
\end{tabular}

5 Ago. Nov.

Jacaranda cf. copaia

Platymiscium cf. duckei

Dinizia excelsa

Hevea guianensis

Peltogyne catingae

6 Set. Dez.

Osteophloeum platyspermum

Erisma fuscum

7 Nov, Fev.

Vouacapoua pallidior

Dipteryx odorata

Cariniana micrantha

Cedrelinga catenaeformis
Whitmore (1975) afirma existir evidências circunstanciais que indicam que, em muitas espécies florestais tropicais, a floração é provocada pelo choque frio ou tensão da água mas essa relação não é simples de explicar. Schulz (1960) encontrou uma relação em Tabebuia serratifolia, no Suriname.

TABELA 2 - Classificação das espécies em grupos por períodos de ocorrência da frutificação.

\begin{tabular}{ccc}
\hline Grupo Época & $\begin{array}{c}\text { Espécies } \\
\text { (Nome científico) }\end{array}$
\end{tabular}

1 Jan. Mai.

Erisma fuscum

Vouacapoua pallidior

Cedrelinga catenaeformis

2 Jan. Ago.

Cariniana micrantha

3 Mar. Ago.

Dipteryx odorata

Copaifera multijuga

Poltogyne paniculata

\begin{tabular}{lll}
\hline 4 & Jun. Out. & Goupia glabra \\
\hline 5 & Jun. Dez. & $\begin{array}{l}\text { Andira unifoliolata } \\
\text { Calophyllum anguiare }\end{array}$ \\
\hline
\end{tabular}

\begin{tabular}{lll}
6 Ago. Dez. & \\
& & Mezilaurus synandra \\
\hline 7 Set. Dez. & \\
& & Virola michelii \\
& Nectandra rubra \\
& Jacaranda cf. copaia \\
& Hevea guianensis \\
& Platymiscium cf. duckei \\
& Tabebuia cf. incana \\
& Anacardium spruceanum \\
& Dinizia excelsa
\end{tabular}

8 Set. Fev.

Pithecolobium racemosum

Manilkara surin

Scleronema micranthum

9 Out. Dez.

Tachigalia paniculata

10 Out. Abr.

Aniba canelilla

Couma macrocarpa

Osteophloeum platyspermum

Peltogyne catingae 
Rayner (1942), Went (1957) e Browning (1971) defendem a hipótese de que a temperatura em seguida às chuvas desempenham papel decisivo na quebra da dormência da gema floral do cafeeiro. Piringer \& Borthwick (1975), segundo Alvin, estudando o cafeeiro, verificaram que todas as plantas em que as gemas florais já haviam sido formadas, foram repetidamente estimuladas a florescer quando se alternavam períodos de seca e irrigação.

Alvin (1966), estudando a floração de "coco", na Bahia, diz que a relação aparente entre a emissão de folhas e a floração parece sugerir que o estímulo para a floração, provavelmente de natureza hormonal, se origina nas folhas relativamente jovens ou recentemente endurecidas; e que houve um acréscimo na floração logo em seguida às primeiras chuvas, depois de um período de reduzida precipitação; e que essa passagem brusca de um período seco para um período úmido parece ser importante fator de controle da intensidade da floração de muitas espécies tropicais.

Acreditamos que, além das chuvas, outros fatores climáticos possam influenciar a floração, como a umidade relativa do ar, a temperatura e o fotoperíodo, aliados a fatores fisiológicos.

Os resultados da análise de regressão apresentados mostraram que houve uma tendência de ser observađo um maior número de árvores iniciando a floração quando ocorreram menores valores de umidade relativa.

Alvin afirma que, aparentemente, um aumento de umidade relativa após um período seco pode induzir a floração do café; Alvin (1966) acha que o principal fator climático associado com o decréscimo ou completa ausência de floração em "coco", parece ser a baixa temperatura durante o período. Ainda Alvin, estudando a floração do "café", afirma que, nas regiões tropicais, não há alterações bem definidas entre períodos secos e chuvosos, e as condições fotoperiódicas são sempre favoráveis para a diferenciação floral; o número de gemas florais tende a reduzir-se quando as plantas são submetidas a temperaturas relativamente altas e que o tempo necessário para as gemas se abrirem é também influenciado pela termoperiodicidade do ambiente. Sabe-se que os efeitos de altas tem- peraturas sobre a atrofia floral do café, estudados por Went (1957) resultariam aparentemente do déficit interno de água provocado por intensidade de transpiração mais elevada. Alvin (1958) acha que a interrupção da dormência e a subseqüente antese das gemas florais do café é regulada por um mecanismo químico e hormonal, controlado pela produção ou liberação de uma "Giberelina" da própria planta através de trocas no curso do mecanismos respiratório; e que o ácido abiscísico (ABA) é o principal inibidor de crescimento associado ao mecanismo de dormência das árvores de climas temperados.

Além dos fatores climáticos e fisiológicos apresentados, a floração pode ser influenciada também pela combinação de fatores bióticos e abióticos.

Bawa (1974) descobriu que uma alta proporçăo de espécies é obrigada a fazer a panmixia e, considerando que a polinizaçăo anemófila é rara nos trópicos, elas dependem de animais para a transferência do polem.

Macedo (1977) estudando a dispersão de 42 espécies lenhosas de "campina", verificou que 22 são ornitocóricas e apenas 5 são do tipo anemocórico e que os grupos anemocóriso, autocórico, barocórico, diszoocórico, primatocórico e quiroptecórico são representados em menor número.

Frankie, Baker \& Opler (1974) relatam que, para as espécies que não floram regularmente cada ano, muitos pesquisadores discutem essa irreguiaridade como sendo uma "fuga" de predação de sementes.

Janzen (1971) relata o comportamento de coletar néctar ou polem, de abelhas tropicais Euglossinae, Xylocopidae e Anthophoridae, denominando-o de "trap lining", quando a abelha visita regularmente inúmeras plantas para obter a quantidade suficiente de néctar. Considerando que muitas dessas árvores são da mesma espécie, esse movimento permite uma panmixia efetiva dessas espécies; e as árvores adaptadas a este sistema acomodariam as abelhas visitantes produzindo somente algumas flores diariamente por um extenso período de tempo.

Baker (1973) apresenta a evidência de que, entre alguns morcegos neotrópicos e as flores visitadas, também se estabelece a sín- 
TABELA 3 - Duração da floração por espécie

\begin{tabular}{|c|c|c|c|}
\hline $\begin{array}{l}\text { N.o } \\
\text { Esp. }\end{array}$ & ESPECIE & $\begin{array}{l}\text { Intervalo } \\
\text { observado } \\
\text { (meses) }\end{array}$ & $\begin{array}{l}\text { Duração } \\
\text { mais fre- } \\
\text { quiente } \\
\text { (meses) }\end{array}$ \\
\hline & & & - \\
\hline 1 & Virola michelii Heckel & $1-6$ & 3 \\
\hline 2 & $\begin{array}{l}\text { Vouacapoua pallidior } \\
\text { Ducke }\end{array}$ & $1-3$ & 2 \\
\hline 3 & Erisma fuscum Ducke & $1-4$ & 2 \\
\hline 4 & $\begin{array}{l}\text { Mezilaurus synandra } \\
\text { (Mez) Kost. }\end{array}$ & $2-4$ & 3 \\
\hline 5 & $\begin{array}{l}\text { Nectandra rubra }(\mathrm{Mez}) \\
\text { C. K. Allen }\end{array}$ & $2-5$ & 2 \\
\hline 6 & $\begin{array}{l}\text { Jacaranda cf, copaia } \\
\text { (Aubl.) D. Don }\end{array}$ & $1-4$ & 3 \\
\hline 7 & Hevea guianensis Aub]. & $1-5$ & 3 \\
\hline 8 & $\begin{array}{l}\text { Platymiscium ef. duckei } \\
\text { Huber }\end{array}$ & $1-3$ & 3 \\
\hline 9 & Dipteryx odorata (Aubl.) & & \\
\hline 10 & $\begin{array}{l}\text { Willd. } \\
\text { Dinizia excelsa Ducke }\end{array}$ & $\begin{array}{l}1-5 \\
1-4\end{array}$ & $\begin{array}{l}4 \\
3\end{array}$ \\
\hline 11 & $\begin{array}{l}\text { Couma macrocarpa } \\
\text { Barb. Rodr. }\end{array}$ & $2-4$ & 3 \\
\hline 12 & $\begin{array}{l}\text { Calophyllum angulare } \\
\text { A. C. Smith }\end{array}$ & $2-4$ & 2 \\
\hline 13 & $\begin{array}{l}\text { Andira unifoliolata } \\
\text { Ducke }\end{array}$ & $2-4$ & \\
\hline 14 & Aniba canelilla (H.B.K.) & $2-4$ & 3 \\
\hline & Mez & $1-4$ & 3 \\
\hline 15 & Goupia glabra Aubl. & $1-4$ & 2 \\
\hline 16 & $\begin{array}{l}\text { Osteophioeum platysper- } \\
\text { num (A.D.C.) Warb. }\end{array}$ & $2-5$ & 5 \\
\hline 17 & Copaifera multijuga & & \\
\hline 18 & $\begin{array}{l}\text { Hayne } \\
\text { Peltogyne catingae } \\
\text { Ducke subsp. glabra } \\
\text { (W. Rodr.) M. F. da }\end{array}$ & $1-5$ & 3 \\
\hline 19 & $\begin{array}{l}\text { Silva } \\
\text { Peltogyne paniculata }\end{array}$ & $2-4$ & 2 \\
\hline 20 & $\begin{array}{l}\text { Benth subsp. paniculata } \\
\text { Pithecolobium racemo. }\end{array}$ & $2-4$ & 3 \\
\hline 21 & $\begin{array}{l}\text { Sum Ducke } \\
\text { Scleronema micranthum }\end{array}$ & $2-6$ & 4 \\
\hline 22 & $\begin{array}{l}\text { Ducke } \\
\text { Tachigalia paniculata }\end{array}$ & $2-7$ & 3 \\
\hline 23 & $\begin{array}{l}\text { Aubl. } \\
\text { Tabebuia cf. incana }\end{array}$ & $1-4$ & 1 \\
\hline 24 & $\begin{array}{l}\text { A. Gentry } \\
\text { Anacardium spruceanum }\end{array}$ & $1-3$ & 1 \\
\hline 25 & $\begin{array}{l}\text { Benth. ex Engl. } \\
\text { Cariniana micrantha }\end{array}$ & $1-4$ & 3 \\
\hline 26 & $\begin{array}{l}\text { Ducke } \\
\text { Manilkara surinamensis }\end{array}$ & $1-3$ & 2 \\
\hline & (Miq.) Dub. & $2-5$ & 4 \\
\hline 27 & $\begin{array}{l}\text { Cedrelinga catenaefor- } \\
\text { mis Ducke }\end{array}$ & $1-3$ & 2 \\
\hline
\end{tabular}

TABELA 4 - Duração da frutificação por espécie

\begin{tabular}{|c|c|c|c|}
\hline $\begin{array}{l}\text { N.o } \\
\text { Esp. }\end{array}$ & ESPECIE & $\begin{array}{l}\text { Intervalo } \\
\text { observado } \\
\text { (meses) }\end{array}$ & $\begin{array}{l}\text { Duraçăo } \\
\text { mais fre- } \\
\text { qüente } \\
\text { (meses) }\end{array}$ \\
\hline 1 & Virola michelii Heckel & $2-4$ & 4 \\
\hline 2 & $\begin{array}{l}\text { Vouacapoua pallidior } \\
\text { Ducke }\end{array}$ & $3-5$ & 4 \\
\hline 3 & Erisma fuscum Ducke & $1-5$ & 5 \\
\hline 4 & $\begin{array}{l}\text { Mezilaurus synandra } \\
\text { (Mez) Kost. }\end{array}$ & $3-7$ & 4 \\
\hline 5 & $\begin{array}{l}\text { Nectandra rubra (Mez) } \\
\text { C.K. Allen }\end{array}$ & $1-8$ & 4 \\
\hline 6 & $\begin{array}{l}\text { Jacaranda cf. copaia } \\
\text { (Aubl.) D. Don }\end{array}$ & $1-4$ & 3 \\
\hline $\begin{array}{l}7 \\
8\end{array}$ & $\begin{array}{l}\text { Hevea guianensis Aubl. } \\
\text { Platymiscium cf. duckei }\end{array}$ & $2-8$ & 5 \\
\hline 9 & $\begin{array}{l}\text { Huber } \\
\text { Dipteryx odorata (Aubl.) } \\
\text { Willd. }\end{array}$ & $1-5$ & 5 \\
\hline 10 & Dinizia excelsa Ducke & $1-9$ & 8 \\
\hline 11 & $\begin{array}{l}\text { Couma macrocarpa } \\
\text { Barb. Rodr. }\end{array}$ & $2-6$ & 4 \\
\hline 12 & $\begin{array}{l}\text { Calophyllum angulare } \\
\text { A.C. Smith }\end{array}$ & $2-6$ & 6 \\
\hline 13 & $\begin{array}{l}\text { Andira unifoliolata } \\
\text { Ducke }\end{array}$ & $1-9$ & 5 \\
\hline 14 & $\begin{array}{l}\text { Aniba canelilla (H.B.K.) } \\
\text { Mez }\end{array}$ & $1-6$ & 5 \\
\hline $\begin{array}{l}15 \\
16\end{array}$ & $\begin{array}{l}\text { Goupia glabra Aubl. } \\
\text { Osteophloeum platysper. }\end{array}$ & $2-6$ & 5 \\
\hline 17 & $\begin{array}{l}\text { mum (A.D.C.) Warb. } \\
\text { Copaifera multijuga } \\
\text { Hayne }\end{array}$ & $1-7$ & 5 \\
\hline 18 & $\begin{array}{l}\text { Hayne } \\
\text { Peltogyne catingae } \\
\text { Ducke subsp. glabra } \\
\text { (W. Rodr.) M.F. da }\end{array}$ & $2-7$ & 5 \\
\hline 19 & $\begin{array}{l}\text { Silva } \\
\text { Peltogyne paniculata } \\
\text { Benth subsp. panicu- } \\
\text { lata }\end{array}$ & $1-4$ & 3 \\
\hline 20 & $\begin{array}{l}\text { Pithecolobium rocemo. } \\
\text { sum Ducke }\end{array}$ & $2-6$ & 3 \\
\hline 21 & Scleronema micranthum & & r \\
\hline 22 & $\begin{array}{l}\text { Ducke } \\
\text { Tachigalia paniculata }\end{array}$ & $1-9$ & 5 \\
\hline 23 & $\begin{array}{l}\text { Aubl. } \\
\text { Tabebuia cf. incana }\end{array}$ & 3 & 3 \\
\hline 24 & $\begin{array}{l}\text { A. Gentry } \\
\text { Anacardium spruceanum }\end{array}$ & $1-3$ & 2 \\
\hline 25 & $\begin{array}{l}\text { Benth. ex Engl. } \\
\text { Cariniana micrantha }\end{array}$ & $1-2$ & 1 \\
\hline 26 & $\begin{array}{l}\text { Ducke } \\
\text { Manilkara surinamensis }\end{array}$ & $1-8$ & 6 \\
\hline 27 & $\begin{array}{l}\text { (Miq.) Dub. } \\
\text { Cedrelinga catenaefor- } \\
\text { mis Ducke }\end{array}$ & $\begin{array}{l}1-7 \\
1-3\end{array}$ & 2 \\
\hline
\end{tabular}


TABELA 5 - Duração mais freqüente em meses da floração e frutificação

\begin{tabular}{c|c|c|r|r}
\hline \multirow{2}{*}{$\begin{array}{c}\text { Duração } \\
\text { (meses) }\end{array}$} & \multicolumn{2}{|c|}{ Freqüência } & \multicolumn{2}{|c}{ Freqüiência \% } \\
\cline { 2 - 4 } & Floração & Frutificação & Floração & Frutificação \\
\hline 1 & 2 & 1 & 7,41 & 3,70 \\
\hline 2 & 8 & 3 & 29,63 & 11,11 \\
\hline 3 & 13 & 4 & 48,15 & 14,82 \\
\hline 4 & 3 & 6 & 11,11 & 22,22 \\
\hline 5 & 1 & 9 & 3,70 & 33,34 \\
\hline 6 & - & - & 7,41 \\
\hline 7 & - & 1 & - & 3,70 \\
\hline 8 & - & 1 & - & 3,70 \\
\hline Total & 27 & 27 & 100,0 & 100,0 \\
\hline
\end{tabular}

drome do conjunto de flores que uma abelha poliniza.

Em nosso trabalho, não foi possível realizar estudos sobre a influência desses fatores bióticos e abióticos nas fenofases analisadas. É un campo de grande interesse para a pesquisa e deve ser desenvolvido paralelamente com estudos sobre a biologia e fisiologia das árvores, aliados aos dados climáticos, porque a floresta amazônica constitui um ecossistema complexo, difícil de ser compreendido.

Quanto à frutificação, concluímos que $70,38 \%$ das espécies frutificaram entre setem. bro $\in$ maio (Tabela 2).

Os resultados da análise de regressão apresentados mostraram que para maior número de árvores, em início de frutificação, houve a tendência de serem observados menores valores de precipitação e umidade relativa (gráficos 39,40 e 41). Todavia a frutificação acompanha o período chuvoso (gráficos 1 a 27).

Araujo (1970), utilizando dados deste fenológico, também verificou que a maior incidência de frutos se dá no período das chuvas. Entretanto, podemos encontrar frutos durante todo o ano (gráficos 1 a 27) se bem que em menor quantidede.

Vimos que muitas espécies frutificaram anualmente, bianualmente e outras de modo irregular. Longman \& Jenik (1974) afirmam que, embora as espécies florestais tropicais possam florescer cada ano, elas não produzem frutos freqüentemente e relatam que a frutificaçãc bianual é uma característica de todas as árvores da família das Vochysiaceae, e a maioria das Lecythidaceae, Burseraceae e Leguminosae, nas florestas tropicais do Suriname (Schultz, 1960) .

Quanto à correlação com a temperatura máxima absoluta, os resultados apresentados indicam que, para maiores valores de início de frutificação, a tendência é serem observados maiores valores desta temperatura.

Com referência à periodicidade do início da floração e frutificaçāo, observada em dois estratos da floresta (dossel e dossel inferior). vimos pelo teste não paramétrico $\mathrm{H}$ de Kruskal Wallis, que os dois estratos variaram significativamente, tratando-se portanto de populações diferentes. Podemos ainda observar pelos gráficos (42 e 43), que houve um maior número de árvores do dossel em início de floração e frutificação, do que do dossel inferior, durante o período de 12 anos. Entretanto, houve meses (julho 68; novembro 69; novembro 71: janeiro 72 ; agosto 73 ; dezembro 74 ; julho 75) em que ocorreu um maior número de árvores do dossel inferior em início de floração e meses (julho 66; outubro 68; junho 69; novembro 70 ; abril 73 ) em que o número de árvores foi igual nesses dois estratos.

Achamos, por isso, que o fator luz é também importante na floração e conseqüente frutificação de espécies florestais.

Conceição (1977) estudando a determinação do ponto de compensação de luz, em 5 estratos descritos por Prance et al. (1976), numa floresta úmida de terra firme, bem próxima à Reserva Ducke, afirma :

.. parece haver uma maior correlaçāo entre a altura dos estratos como um todo com a média do ponto de compensação de luz, do que entre a altura de plantas individuais que compōem um determinado estrato e o ponto de compensação.

Ainda, o mesmo autor, relata que os estratos cada vez mais baixos necessitam de menores intensidades de luz para realizar a fotossíntese, variando em média entre 200 Lux no piso da floresta a 2.300 no estrato emergente 
TABELA 6 - Tempo de vida da folha e tipos de mudança foliar

\begin{tabular}{|c|c|c|c|}
\hline $\begin{array}{l}\text { N.: } \\
\text { Espécie }\end{array}$ & Espécie & $\begin{array}{c}\text { Tempo de vida } \\
\text { da folha } \\
\text { (meses) }\end{array}$ & Tipos de mudança foliar \\
\hline 1 & Virola michelii Heckel & $7-13$ & $\begin{array}{l}\text { Perenifolia; raramente semicaducifoilia antes } \\
\text { da floração. Foi observada com poucas folhas } \\
\text { duas vezes, em } 12 \text { anos (set. } 75 \text { e jul. } 76 \text { ). }\end{array}$ \\
\hline 2 & Vouacapoua pallidior Ducke & $5-25$ & $\begin{array}{l}\text { Perenifolia; algumas vezes semicaducifolia } \\
\text { antes da floração e no fim da frutificação. }\end{array}$ \\
\hline 3 & Erisma fuscum Ducke & $3-12$ & $\begin{array}{l}\text { Semicaducifolia entre jul. - set., antes da flora- } \\
\text { ção, mas não freqüentemente. }\end{array}$ \\
\hline 4 & Mezilaurus synandra (Mez) Kost. & $6-16$ & $\begin{array}{l}\text { Perenifolia; foi observada com poucas folhas } \\
\text { uma vez (mai. 75). }\end{array}$ \\
\hline 5 & Nectandra rubra (Mez) C. K. Allen & $7-18$ & Semicaducifolia, durante a floração. \\
\hline 6 & Jacaranda cf. copaia (Aub|.) D. Don & $8-20$ & $\begin{array}{l}\text { Perenifolia; semicaducifolia, algumas vezes, } \\
\text { antes da floraçāo. }\end{array}$ \\
\hline 7 & Hevea guianensis Aubl. & $8-12$ & Caducifolia, antes da floração. \\
\hline 8 & Platymiscium cf. duckei Huber & $8-12$ & Semicaducifolia durante a floração. \\
\hline 9 & Dipteryx odorata (Aubl.) Willd. & $4-12$ & $\begin{array}{l}\text { Perenifolia; algumas vezes semicaducifolia na } \\
\text { estação seca. }\end{array}$ \\
\hline 10 & Dinizia excelsa Ducke & $6-13$ & Semicaducifolia, antes da floração. \\
\hline 11 & Couma macrocarpa Barb. Rodr. & $8-12$ & Semicaducifolia, antes da floração. \\
\hline 12 & Calophyllum angulare A.C. Smith & $8-13$ & $\begin{array}{l}\text { Perenifolia; foi observada com poucas folhas } \\
\text { uma vez (dez. 76). }\end{array}$ \\
\hline 13 & Andira unifoliolata Ducke & $6-22$ & $\begin{array}{l}\text { Perenifolia; algumas vezes semicaducifolia, an } \\
\text { tes da floração e durante a frutificação. }\end{array}$ \\
\hline 14 & Aniba canelilla (H.B.K) $\mathrm{Mez}$ & $5-11$ & $\begin{array}{l}\text { Perenifolia; algumas vezes, semicaducifolia, an } \\
\text { tes da floração, entre maio e junho. }\end{array}$ \\
\hline 15 & Goupia glabra Aubl. & $5-19$ & $\begin{array}{l}\text { Perenifolia; algumas vezes, semicaducifolia. } \\
\text { durante a floração. }\end{array}$ \\
\hline 16 & $\begin{array}{l}\text { Osteoprloeum platyspermum (A.D.C.) } \\
\text { Warb. }\end{array}$ & $4-24$ & $\begin{array}{l}\text { Perenifolia; nunca foi observada com pouca } \\
\text { folha, durante } 12 \text { anos. }\end{array}$ \\
\hline 17 & Copaifera multijuga Hayne & $10-12$ & $\begin{array}{l}\text { Perenifolia; algumas vezes, semicaducifolia no } \\
\text { fim da frutificação. }\end{array}$ \\
\hline 18 & $\begin{array}{l}\text { Peltogyne catingae Ducke subsp. gla } \\
\text { bra (W. Rodr.) M.F. da Silva }\end{array}$ & $6-16$ & Semicaducifolia, antes da floraçāo. \\
\hline 19 & $\begin{array}{l}\text { Peltogyne paniculata Benth subsp. } \\
\text { paniculata }\end{array}$ & $5-17$ & $\begin{array}{l}\text { Semicaducifolia, entre a floração e a frutifi- } \\
\text { cação. }\end{array}$ \\
\hline 20 & Pithecolobium racemosum Ducke & $4-17$ & $\begin{array}{l}\text { Perenifolia; algumas vezes, semicaducifolia, } \\
\text { durante a floração. }\end{array}$ \\
\hline 21 & Scleronema micranthum Ducke & $10-16$ & $\begin{array}{l}\text { Perenifolia; raramente, semicaducifolia, an. } \\
\text { tes e durante a floração. }\end{array}$ \\
\hline 22 & Tachigalia paniculata Aubl. & $7-13$ & $\begin{array}{l}\text { Perenifolia; raramente, semicaducifolia, an- } \\
\text { tes da floração. }\end{array}$ \\
\hline 23 & Tabebuia cf. incana A. Gentry & $7-15$ & Caducifolia, durante a floração. \\
\hline 24 & $\begin{array}{l}\text { Anacardium spruceanum Benth. ex } \\
\text { Engl. }\end{array}$ & $4-15$ & Semicaducifolia, antes da floração. \\
\hline 25 & Cariniana micrantha Ducke & $6-15$ & Caducifolia, no fim da frutificação. \\
\hline 26 & Manilkara surinamensis (Miq.) Dub & $7-20$ & $\begin{array}{l}\text { Perenifolia; algumas vezes, semicaducifolia } \\
\text { antes da floração. }\end{array}$ \\
\hline 27 & Cedrelinga catenaeformis Ducke & $7-14$ & $\begin{array}{l}\text { Perenifolia; foi observada com pouca folha } \\
\text { apenas uma vez (ago. 75). }\end{array}$ \\
\hline & 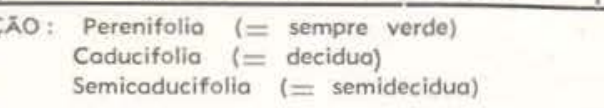 & & . \\
\hline
\end{tabular}

Fenologia de... 
TABELA 7 - Caractetísticas das ârvores observadas

\begin{tabular}{|c|c|c|c|c|c|c|c|c|c|c|c|c|}
\hline \multirow[t]{2}{*}{ N.॰ } & \multirow[t]{2}{*}{ Espécie } & \multirow{2}{*}{\begin{tabular}{c|} 
N.॰ árv. \\
no feno- \\
lógico
\end{tabular}} & \multirow{2}{*}{$\begin{array}{l}\text { C.A.P. } \\
(\mathrm{cm})\end{array}$} & \multirow{2}{*}{$\left|\begin{array}{c}\text { Alt. fuste } \\
\text { comerc. } \\
\text { (m) }\end{array}\right|$} & \multirow{2}{*}{$\begin{array}{l}\text { Altura } \\
\text { total } \\
(\mathrm{m})\end{array}$} & \multirow{2}{*}{$\begin{array}{l}\text { Forma } \\
\text { do } \\
\text { fuste }\end{array}$} & \multicolumn{2}{|c|}{$\begin{array}{l}\text { Diâmetro da } \\
\text { copa }(\mathrm{m})\end{array}$} & \multirow{2}{*}{$\begin{array}{c}\text { Forma } \\
\text { da } \\
\text { copa }\end{array}$} & \multirow{2}{*}{$\begin{array}{c}\text { Posição } \\
\text { da } \\
\text { copa }\end{array}$} & \multirow{2}{*}{$\begin{array}{l}\text { N. Her- } \\
\text { bario } \\
\text { INPA }\end{array}$} & \multirow[t]{2}{*}{ Família } \\
\hline & & & & & & & Maior & Menor & & & & \\
\hline 1 & Virola michelii Heckel & $\begin{array}{c}154 \\
169 \\
170\end{array}$ & $\begin{array}{l}205 \\
190 \\
203\end{array}$ & $\begin{array}{l}26,50 \\
22,80 \\
22,00\end{array}$ & $\begin{array}{l}34,50 \\
33,00 \\
29,00\end{array}$ & $\begin{array}{l}3 \\
5 \\
5\end{array}$ & $\begin{array}{l}13.0 \\
13.1 \\
10,0\end{array}$ & $\begin{array}{r}13,0 \\
6,5 \\
12,6\end{array}$ & $\begin{array}{l}3 \\
3 \\
4\end{array}$ & $\begin{array}{l}4 \\
4 \\
3\end{array}$ & $\begin{array}{l}55.240 \\
58.213 \\
58.207\end{array}$ & Myristicaceae \\
\hline 2 & Vouacapoua pallidior Ducke & $\begin{array}{l}31 \\
32 \\
50\end{array}$ & $\begin{array}{l}81 \\
78 \\
96\end{array}$ & $\begin{array}{r}11,80 \\
6,40 \\
8,00\end{array}$ & $\begin{array}{l}18,00 \\
14,00 \\
17,60\end{array}$ & $\begin{array}{l}4 \\
4 \\
4\end{array}$ & $\begin{array}{l}6,3 \\
8,5 \\
9,4\end{array}$ & $\begin{array}{l}5,9 \\
8,0 \\
9,0\end{array}$ & $\begin{array}{l}3 \\
4 \\
4\end{array}$ & $\begin{array}{l}3 \\
3 \\
3\end{array}$ & $\begin{array}{l}57.690 \\
58.691 \\
57.692\end{array}$ & $\begin{array}{l}\text { Leguminosae } \\
\text { Caesalp. }\end{array}$ \\
\hline 3 & Erisma fuscum Ducke & $\begin{array}{l}210 \\
188 \\
173\end{array}$ & $\begin{array}{l}173 \\
134 \\
134\end{array}$ & $\begin{array}{l}19,50 \\
17,00 \\
24,30\end{array}$ & $\begin{array}{l}25,00 \\
27,00 \\
33,00\end{array}$ & $\begin{array}{l}5 \\
5 \\
4\end{array}$ & $\begin{array}{r}8,4 \\
10,0 \\
10,0\end{array}$ & $\begin{array}{r}8,4 \\
10,0 \\
9,7\end{array}$ & $\begin{array}{l}3 \\
4 \\
4\end{array}$ & $\begin{array}{l}1 \\
3 \\
4\end{array}$ & $\begin{array}{l}55.265 \\
55.246 \\
57.906\end{array}$ & Vochysiaceae \\
\hline 4 & Mezilaurus synandra (Mez) Kost. & $\begin{array}{r}184 \\
22 \\
185\end{array}$ & $\begin{array}{l}105 \\
148 \\
107\end{array}$ & $\begin{array}{l}18,00 \\
18,50 \\
15,00\end{array}$ & $\begin{array}{l}24,90 \\
29,50 \\
34,00\end{array}$ & $\begin{array}{l}2 \\
2 \\
4\end{array}$ & $\begin{array}{l}6,2 \\
9,5 \\
5,5\end{array}$ & $\begin{array}{l}4,5 \\
9,0 \\
5,1\end{array}$ & $\begin{array}{l}4 \\
4 \\
4\end{array}$ & $\begin{array}{l}4 \\
3 \\
4\end{array}$ & $\begin{array}{l}57.755 \\
60.171 \\
57.753\end{array}$ & Lauraceae \\
\hline 5 & $\begin{array}{l}\text { Nectandra rubra (Mez) } \\
\text { C. K. Allen }\end{array}$ & $\begin{array}{r}25 \\
161 \\
65\end{array}$ & $\begin{array}{l}300 \\
184 \\
220\end{array}$ & $\begin{array}{l}20,10 \\
25,20 \\
16,00\end{array}$ & $\begin{array}{l}36,00 \\
37,50 \\
40,00\end{array}$ & $\begin{array}{l}4 \\
4 \\
6\end{array}$ & $\begin{array}{l}20,5 \\
12,0 \\
16,5\end{array}$ & $\begin{array}{r}19,0 \\
8,0 \\
16,0\end{array}$ & $\begin{array}{l}4 \\
3 \\
4\end{array}$ & $\begin{array}{l}4 \\
4 \\
3\end{array}$ & $\begin{array}{l}57.746 \\
57.754 \\
57.749\end{array}$ & Lauraceae \\
\hline 6 & $\begin{array}{l}\text { Jacaranda cf. copaia } \\
\text { (Aubl,) D. Don }\end{array}$ & $\begin{array}{r}200 \\
201 \\
61\end{array}$ & $\begin{array}{l}57 \\
90 \\
75\end{array}$ & $\begin{array}{l}16,80 \\
21,00 \\
13,40\end{array}$ & $\begin{array}{l}18,00 \\
27,00 \\
19,60\end{array}$ & $\begin{array}{l}5 \\
3 \\
3\end{array}$ & $\begin{array}{l}3,3 \\
6,6 \\
7, ;\end{array}$ & $\begin{array}{l}3,1 \\
6,3 \\
6,5\end{array}$ & $\begin{array}{l}4 \\
4 \\
4\end{array}$ & $\begin{array}{l}3 \\
3 \\
1\end{array}$ & $\begin{array}{l}58.187 \\
58.255 \\
58.189\end{array}$ & Bignoniaceae \\
\hline 7 & Hevea guianensis Aubl. & $\begin{array}{r}7 \\
49 \\
40\end{array}$ & $\begin{array}{l}182 \\
195 \\
184\end{array}$ & $\begin{array}{l}23,40 \\
13,50 \\
12,30\end{array}$ & $\begin{array}{l}33,00 \\
43,50 \\
36,30\end{array}$ & $\begin{array}{l}5 \\
2 \\
2\end{array}$ & $\begin{array}{r}15,0 \\
12,5 \\
9,8\end{array}$ & $\begin{array}{r}12,4 \\
11,6 \\
7,0\end{array}$ & $\begin{array}{l}4 \\
4 \\
4\end{array}$ & $\begin{array}{l}4 \\
4 \\
4\end{array}$ & $\begin{array}{l}57.806 \\
57.786 \\
57.804\end{array}$ & Euphorbiaceae \\
\hline 8 & Platymiscium cf. duckei Huber & $\begin{array}{r}99 \\
112 \\
130\end{array}$ & $\begin{array}{r}114 \\
183 \\
68\end{array}$ & $\begin{array}{l}20,00 \\
17,50 \\
28,00\end{array}$ & $\begin{array}{l}30,00 \\
27,00 \\
31,00\end{array}$ & $\begin{array}{l}3 \\
3 \\
2\end{array}$ & $\begin{array}{r}8,7 \\
12,9 \\
4,2\end{array}$ & $\begin{array}{l}7,3 \\
9,1 \\
4,0\end{array}$ & $\begin{array}{l}4 \\
2 \\
2\end{array}$ & $\begin{array}{l}3 \\
3 \\
4\end{array}$ & $\begin{array}{l}57.621 \\
55.700 \\
55.387\end{array}$ & $\begin{array}{l}\text { Leguminosae } \\
\text { Papil. }\end{array}$ \\
\hline 9 & Dipteryx odorata (Aubl.) Willn. & $\begin{array}{r}55 \\
174 \\
118\end{array}$ & $\begin{array}{l}105 \\
178 \\
203\end{array}$ & $\begin{array}{l}13,30 \\
18,90 \\
16,50\end{array}$ & $\begin{array}{l}24,30 \\
33,90 \\
26,50\end{array}$ & $\begin{array}{l}4 \\
3 \\
6\end{array}$ & $\begin{array}{r}9,0 \\
12,3 \\
10,0\end{array}$ & $\begin{array}{r}7,0 \\
11,3 \\
10,0\end{array}$ & $\begin{array}{l}3 \\
4 \\
4\end{array}$ & $\begin{array}{l}3 \\
4 \\
4\end{array}$ & $\begin{array}{l}57.633 \\
57.628 \\
55.255\end{array}$ & $\begin{array}{l}\text { Leguminosee } \\
\text { Papil. }\end{array}$ \\
\hline
\end{tabular}




\begin{tabular}{|c|c|c|c|c|c|c|c|c|c|c|c|c|}
\hline \multirow{2}{*}{ N.0 } & \multirow[t]{2}{*}{ Espécie } & \multirow{2}{*}{$\begin{array}{c}\text { N.árv. } \\
\text { no feno- } \\
\text { lógico }\end{array}$} & \multirow[t]{2}{*}{$\begin{array}{l}\text { C.A.P. } \\
(\mathrm{cm})\end{array}$} & \multirow{2}{*}{$\begin{array}{c}\text { Alt. fuste } \\
\text { comerc. } \\
(\mathrm{m})\end{array}$} & \multirow{2}{*}{$\begin{array}{l}\text { Altura } \\
\text { total } \\
(\mathrm{m}) \\
\end{array}$} & \multirow{2}{*}{$\begin{array}{c}\text { Forma } \\
\text { do } \\
\text { fuste }\end{array}$} & \multicolumn{2}{|c|}{$\begin{array}{l}\text { Diâmetro da } \\
\text { copa }(\mathrm{m})\end{array}$} & \multirow{2}{*}{$\begin{array}{c}\text { Forma } \\
\text { da } \\
\text { copa }\end{array}$} & \multirow{2}{*}{$\begin{array}{c}\text { Posição } \\
\text { da } \\
\text { copa }\end{array}$} & \multirow{2}{*}{$\begin{array}{c}\text { N.० Her- } \\
\text { bario } \\
\text { INPA }\end{array}$} & \multirow[t]{2}{*}{ Família } \\
\hline & & & & & & & Maior & Menor & & & & \\
\hline 10 & Dinizia excelsa Ducke & $\begin{array}{l}80 \\
54 \\
95\end{array}$ & $\begin{array}{l}240 \\
192 \\
259\end{array}$ & $\begin{array}{l}15,90 \\
22,80 \\
23,40\end{array}$ & $\begin{array}{l}39,00 \\
34,50 \\
44,00\end{array}$ & $\begin{array}{l}4 \\
5 \\
5\end{array}$ & $\begin{array}{l}28,0 \\
13,8 \\
24,0\end{array}$ & $\begin{array}{l}26,0 \\
13,2 \\
22,5\end{array}$ & $\begin{array}{l}4 \\
4 \\
4\end{array}$ & $\begin{array}{l}5 \\
3 \\
4\end{array}$ & $\begin{array}{l}57.719 \\
57.718 \\
57.706\end{array}$ & $\begin{array}{l}\text { Leguminosae } \\
\text { Mimos. }\end{array}$ \\
\hline 11 & Couma macrocarpa Barb. Rođr. & $\begin{array}{l}107 \\
179 \\
193\end{array}$ & $\begin{array}{r}93 \\
110 \\
153\end{array}$ & $\begin{array}{l}14,50 \\
15,50 \\
19,50\end{array}$ & $\begin{array}{l}22,00 \\
22,50 \\
28,50\end{array}$ & $\begin{array}{l}4 \\
3 \\
5\end{array}$ & $\begin{array}{r}9,0 \\
5,0 \\
15,7\end{array}$ & $\begin{array}{l}9,0 \\
5,0 \\
7,2\end{array}$ & $\begin{array}{l}2 \\
4 \\
3\end{array}$ & $\begin{array}{l}3 \\
3 \\
3\end{array}$ & $\begin{array}{l}55.209 \\
55.219 \\
57.516\end{array}$ & Apocynaceae \\
\hline 12 & Calophyllum angulare A.C. Smith & $\begin{array}{r}123 \\
75 \\
109\end{array}$ & $\begin{array}{l}150 \\
172 \\
183\end{array}$ & $\begin{array}{l}26,10 \\
14,10 \\
28,50\end{array}$ & $\begin{array}{l}30,20 \\
27,90 \\
40,50\end{array}$ & $\begin{array}{l}4 \\
5 \\
3\end{array}$ & $\begin{array}{r}9,3 \\
8,9 \\
10,0\end{array}$ & $\begin{array}{l}8,4 \\
8,0 \\
8,0\end{array}$ & $\begin{array}{l}4 \\
4 \\
4\end{array}$ & $\begin{array}{l}4 \\
3 \\
4\end{array}$ & $\begin{array}{l}58.178 \\
58.174 \\
58.176\end{array}$ & Guttiferae \\
\hline 13 & Andira unifoliolata Ducke & $\begin{array}{r}20 \\
13 \\
198\end{array}$ & $\begin{array}{l}125 \\
135 \\
175\end{array}$ & $\begin{array}{l}18,00 \\
19,00 \\
19,50\end{array}$ & $\begin{array}{l}30,50 \\
30,00 \\
31,50\end{array}$ & $\begin{array}{l}6 \\
6 \\
6\end{array}$ & $\begin{array}{r}8,2 \\
9,0 \\
16,0\end{array}$ & $\begin{array}{r}8,2 \\
9,0 \\
16,0\end{array}$ & $\begin{array}{l}4 \\
4 \\
2\end{array}$ & $\begin{array}{l}3 \\
3 \\
4\end{array}$ & $\begin{array}{l}54.761 \\
54.756 \\
55.233\end{array}$ & $\begin{array}{l}\text { Leguminosae } \\
\text { Papil. }\end{array}$ \\
\hline 14 & Aniba canelilla (H.B.K.) Mez & $\begin{array}{l}172 \\
119 \\
156\end{array}$ & $\begin{array}{r}94 \\
175 \\
110\end{array}$ & $\begin{array}{l}13,00 \\
18,50 \\
21,00\end{array}$ & $\begin{array}{l}26,00 \\
30,00 \\
31,50\end{array}$ & $\begin{array}{l}3 \\
3 \\
3\end{array}$ & $\begin{array}{l}6,1 \\
7,5 \\
8,3\end{array}$ & $\begin{array}{l}5,7 \\
7,5 \\
6,5\end{array}$ & $\begin{array}{l}3 \\
3 \\
4\end{array}$ & $\begin{array}{l}4 \\
4 \\
3\end{array}$ & $\begin{array}{l}57.751 \\
55.234 \\
54.768\end{array}$ & Lauraceae \\
\hline 15 & Goupia glabra Aubl. & $\begin{array}{r}41 \\
18 \\
150\end{array}$ & $\begin{array}{l}150 \\
235 \\
215\end{array}$ & $\begin{array}{l}19,50 \\
18,50 \\
24,00\end{array}$ & $\begin{array}{l}37,50 \\
35,50 \\
40,50\end{array}$ & $\begin{array}{l}3 \\
5 \\
3\end{array}$ & $\begin{array}{l}10,5 \\
19,5 \\
15,0\end{array}$ & $\begin{array}{r}9,6 \\
19,5 \\
14,0\end{array}$ & $\begin{array}{l}4 \\
4 \\
4\end{array}$ & $\begin{array}{l}3 \\
4 \\
4\end{array}$ & $\begin{array}{l}58.138 \\
54.760 \\
58.137\end{array}$ & $\begin{array}{l}\text { Celastraceae } \\
54.765\end{array}$ \\
\hline 16 & $\begin{array}{l}\text { Osteophloeum platyspermum } \\
\text { (A.D.C.) Warb. }\end{array}$ & $\begin{array}{r}93 \\
175 \\
15\end{array}$ & $\begin{array}{l}160 \\
220 \\
210\end{array}$ & $\begin{array}{l}22,00 \\
20,10 \\
22,00\end{array}$ & $\begin{array}{l}32,00 \\
30,00 \\
36,50\end{array}$ & $\begin{array}{l}3 \\
3 \\
3\end{array}$ & $\begin{array}{r}9,0 \\
14,4 \\
11,2\end{array}$ & $\begin{array}{r}9,0 \\
11,6 \\
11,2\end{array}$ & $\begin{array}{l}4 \\
3 \\
4\end{array}$ & $\begin{array}{l}5 \\
4 \\
4\end{array}$ & $\begin{array}{l}55.752 \\
58.209 \\
54.758\end{array}$ & Myristicaceae \\
\hline 17 & Copaifera multijuga Hayne & $\begin{array}{r}100 \\
125 \\
70\end{array}$ & $\begin{array}{l}150 \\
145 \\
170\end{array}$ & $\begin{array}{l}19,00 \\
21,50 \\
21,90\end{array}$ & $\begin{array}{l}35,00 \\
31,00 \\
37,50\end{array}$ & $\begin{array}{l}5 \\
5 \\
6\end{array}$ & $\begin{array}{l}16,0 \\
12,8 \\
17,5\end{array}$ & $\begin{array}{l}16,0 \\
12,7 \\
17,0\end{array}$ & $\begin{array}{l}5 \\
5 \\
5\end{array}$ & $\begin{array}{l}5 \\
4 \\
4\end{array}$ & $\begin{array}{l}55.747 \\
55.375 \\
57.696\end{array}$ & $\begin{array}{l}\text { Leguminosae } \\
\text { Caesalp. }\end{array}$ \\
\hline 18 & $\begin{array}{l}\text { Peltogyne catingae Ducke subsp. } \\
\text { glabra (W. Rodr.) M. F. da Silva }\end{array}$ & $\begin{array}{l}113 \\
115 \\
183\end{array}$ & $\begin{array}{l}191 \\
283 \\
216\end{array}$ & $\begin{array}{l}25,00 \\
22,00 \\
20,00\end{array}$ & $\begin{array}{l}29,50 \\
33,00 \\
34,00\end{array}$ & $\begin{array}{l}5 \\
5 \\
6\end{array}$ & $\begin{array}{l}8,0 \\
8,2 \\
9,4\end{array}$ & $\begin{array}{l}8,0 \\
9,4 \\
8,2\end{array}$ & $\begin{array}{l}3 \\
4 \\
3\end{array}$ & $\begin{array}{l}1 \\
5 \\
5\end{array}$ & $\begin{array}{l}55.266 \\
55.262 \\
55.254\end{array}$ & $\begin{array}{l}\text { Leguminosae } \\
\text { Caesalp. }\end{array}$ \\
\hline
\end{tabular}


TABELA 7 - (continuaçắo)

\begin{tabular}{|c|c|c|c|c|c|c|c|c|c|c|c|c|}
\hline \multirow[t]{2}{*}{ N. 0} & \multirow{2}{*}{ Espécie } & \multirow{2}{*}{$\begin{array}{l}\text { N.: árv. } \\
\text { no feno- } \\
\text { lógico }\end{array}$} & \multirow{2}{*}{$\begin{array}{l}\text { C.A.P. } \\
(\mathrm{cm})\end{array}$} & \multirow{2}{*}{$\mid \begin{array}{c}\text { Alt. fuste } \\
\text { comerc. } \\
(\mathrm{m})\end{array}$} & \multirow{2}{*}{$\begin{array}{l}\text { Altura } \\
\text { total } \\
(\mathrm{m})\end{array}$} & \multirow{2}{*}{$\begin{array}{c}\text { Forma } \\
\text { do } \\
\text { fuste }\end{array}$} & \multicolumn{2}{|c|}{$\begin{array}{l}\text { Diâmetro da } \\
\text { copa (m) }\end{array}$} & \multirow{2}{*}{$\begin{array}{c}\text { Forma } \\
\text { da } \\
\text { copa }\end{array}$} & \multirow{2}{*}{$\begin{array}{c}\text { Posição } \\
\text { da } \\
\text { copa }\end{array}$} & \multirow{2}{*}{$\mid \begin{array}{c}\text { N.॰ Her- } \\
\text { bário } \\
\text { INPA }\end{array}$} & \multirow[t]{2}{*}{ Familia } \\
\hline & & & & & & & Maior & Menor & & & & \\
\hline 19 & $\begin{array}{l}\text { Peltogyne paniculata Benth } \\
\text { subsp. paniculata }\end{array}$ & $\begin{array}{r}6 \\
181 \\
81\end{array}$ & $\begin{array}{r}214 \\
98 \\
142\end{array}$ & $\begin{array}{l}26,00 \\
22,20 \\
15,00\end{array}$ & $\begin{array}{l}37,50 \\
37,50 \\
24,00\end{array}$ & $\begin{array}{l}4 \\
5 \\
2\end{array}$ & $\begin{array}{r}14,5 \\
8,0 \\
12,2\end{array}$ & $\begin{array}{r}14,5 \\
6,0 \\
10,6\end{array}$ & $\begin{array}{l}3 \\
4 \\
4\end{array}$ & $\begin{array}{l}4 \\
3 \\
3\end{array}$ & $\begin{array}{l}54.748 \\
57.653 \\
57.648\end{array}$ & $\begin{array}{l}\text { Leguminosae } \\
\text { Caesalp. }\end{array}$ \\
\hline 20 & Pithecolobium racemosum Ducke & $\begin{array}{r}2 \\
102 \\
133\end{array}$ & $\begin{array}{r}82 \\
57 \\
118 \\
\end{array}$ & $\begin{array}{r}12,40 \\
7,80 \\
17,00\end{array}$ & $\begin{array}{l}18,80 \\
16,60 \\
29,50\end{array}$ & $\begin{array}{l}2 \\
5 \\
4\end{array}$ & $\begin{array}{l}9,0 \\
6,8 \\
9,4\end{array}$ & $\begin{array}{l}8,6 \\
6,0 \\
9,4\end{array}$ & $\begin{array}{l}4 \\
4 \\
4 \\
4\end{array}$ & $\begin{array}{l}3 \\
3 \\
5\end{array}$ & $\begin{array}{l}57.720 \\
57.713 \\
55.256\end{array}$ & $\begin{array}{l}\text { Leguminosae } \\
\text { Mimos. }\end{array}$ \\
\hline 21 & Scleronema micranthum Ducke & $\begin{array}{r}9 \\
12 \\
28\end{array}$ & $\begin{array}{r}89 \\
181 \\
143\end{array}$ & $\begin{array}{l}12,50 \\
20,00 \\
15,00\end{array}$ & $\begin{array}{l}21,50 \\
33,00 \\
25,20\end{array}$ & $\begin{array}{l}6 \\
6 \\
4\end{array}$ & $\begin{array}{r}5,0 \\
18,0 \\
12,9\end{array}$ & $\begin{array}{r}5,0 \\
18,0 \\
12,0\end{array}$ & $\begin{array}{l}4 \\
4 \\
4\end{array}$ & $\begin{array}{l}3 \\
3 \\
4\end{array}$ & $\begin{array}{l}54.750 \\
54.754 \\
58.179\end{array}$ & Bombacaceae \\
\hline 22 & Tachigalia paniculata Aub!. & $\begin{array}{l}187 \\
189 \\
191\end{array}$ & $\begin{array}{r}96 \\
227 \\
110\end{array}$ & $\begin{array}{l}16,00 \\
12,00 \\
16,50\end{array}$ & $\begin{array}{l}33,00 \\
23,00 \\
19,00\end{array}$ & $\begin{array}{l}4 \\
6 \\
2\end{array}$ & $\begin{array}{l}19,0 \\
21,0 \\
12,8\end{array}$ & $\begin{array}{r}11,0 \\
21,0 \\
9,5\end{array}$ & $\begin{array}{l}4 \\
5 \\
3\end{array}$ & $\begin{array}{l}3 \\
5 \\
2\end{array}$ & $\begin{array}{l}57.655 \\
55.261 \\
57.639\end{array}$ & $\begin{array}{l}\text { Leguminosae } \\
\text { Caesalp. }\end{array}$ \\
\hline 23 & Tabebuia cf. incana A. Gentry & $\begin{array}{l}101 \\
127 \\
134\end{array}$ & $\begin{array}{r}111 \\
170 \\
88\end{array}$ & $\begin{array}{l}29,50 \\
34,80 \\
15,80\end{array}$ & $\begin{array}{l}35,50 \\
39,30 \\
24,00\end{array}$ & $\begin{array}{l}3 \\
3 \\
3\end{array}$ & $\begin{array}{r}4,9 \\
13,2 \\
7,4\end{array}$ & $\begin{array}{r}5,9 \\
11,5 \\
5,8\end{array}$ & $\begin{array}{l}4 \\
4 \\
3\end{array}$ & $\begin{array}{l}3 \\
5 \\
4\end{array}$ & $\begin{array}{l}60.168 \\
58.191 \\
61.712\end{array}$ & Bignoniaceae \\
\hline 24 & $\begin{array}{l}\text { Anacardium spruceanum } \\
\text { Benth. ex. Engl. }\end{array}$ & $\begin{array}{r}153 \\
67 \\
43\end{array}$ & $\begin{array}{l}175 \\
154 \\
136\end{array}$ & $\begin{array}{l}20,00 \\
18,90 \\
15,40\end{array}$ & $\begin{array}{l}31,50 \\
28,20 \\
24,00\end{array}$ & $\begin{array}{l}6 \\
5 \\
3\end{array}$ & $\begin{array}{r}15,0 \\
9,1 \\
9,1\end{array}$ & $\begin{array}{r}15,0 \\
8,4 \\
7,5\end{array}$ & $\begin{array}{l}4 \\
4 \\
4\end{array}$ & $\begin{array}{l}4 \\
2 \\
3\end{array}$ & $\begin{array}{l}55.238 \\
60.167 \\
58.121\end{array}$ & Anacardiaceae \\
\hline 25 & Cariniana micrantha Ducke & $\begin{array}{r}84 \\
92 \\
129\end{array}$ & $\begin{array}{l}280 \\
273 \\
257\end{array}$ & $\begin{array}{l}24,90 \\
24,00 \\
26,00\end{array}$ & $\begin{array}{l}36,90 \\
39,00 \\
37,00\end{array}$ & $\begin{array}{l}4 \\
5 \\
4\end{array}$ & $\begin{array}{l}22,0 \\
22,0 \\
16,2\end{array}$ & $\begin{array}{l}19,8 \\
19,0 \\
15,2\end{array}$ & $\begin{array}{l}4 \\
3 \\
4\end{array}$ & $\begin{array}{l}4 \\
4 \\
5\end{array}$ & $\begin{array}{l}57.536 \\
57.548 \\
57.541\end{array}$ & Lecythidaceae \\
\hline 26 & $\begin{array}{l}\text { Manilkara surinamensis } \\
\text { (Miq.) Dub. }\end{array}$ & $\begin{array}{l}57 \\
66 \\
79\end{array}$ & $\begin{array}{l}134 \\
115 \\
175\end{array}$ & $\begin{array}{l}21,00 \\
11,40 \\
17,70\end{array}$ & $\begin{array}{l}29,00 \\
23,40 \\
24,30\end{array}$ & $\begin{array}{l}5 \\
5 \\
5\end{array}$ & $\begin{array}{r}10,8 \\
8,6 \\
16,1\end{array}$ & $\begin{array}{r}7,2 \\
8,5 \\
10,6\end{array}$ & $\begin{array}{l}4 \\
4 \\
3\end{array}$ & $\begin{array}{l}3 \\
3 \\
3\end{array}$ & $\begin{array}{l}57.813 \\
57.807 \\
57.827\end{array}$ & Sapotaceae \\
\hline 27 & Cedrelinga catenaeformis Ducke & $\begin{array}{l}178 \\
122 \\
105\end{array}$ & $\begin{array}{l}470 \\
285 \\
210\end{array}$ & $\begin{array}{l}18,00 \\
20,00 \\
31,50\end{array}$ & $\begin{array}{l}30,00 \\
33,50 \\
39,00\end{array}$ & $\begin{array}{l}5 \\
3 \\
2\end{array}$ & $\begin{array}{l}11,7 \\
20,0 \\
12,0\end{array}$ & $\begin{array}{l}10,6 \\
20,0 \\
11,0\end{array}$ & $\begin{array}{l}1 \\
2 \\
4\end{array}$ & $\begin{array}{l}4 \\
4 \\
3\end{array}$ & $\begin{array}{l}57.707 \\
55.223 \\
57.711\end{array}$ & $\begin{array}{l}\text { Leguminosae } \\
\text { Mimos. }\end{array}$ \\
\hline
\end{tabular}

2. OBSERVAÇÁO: Forma da Copa (Fig. 1)

2 $\quad$ Posiçáa da Copa (Fig, 2] 
Whitmore (1975) afirma que a principal significância para a árvore ser decídua é á forte redução de perda d'água e que estas árvores nas florestas tropicais são quase totalmente confinadas no estrato superior da mata (dossel) onde a tensão de água é mais sentida.

Conceição (1977) também verificou, estudando a tensão de água em algumas espécies florestais, que as árvores dos estratos superiores desenvolvem ou suportam maiores tensões de água (menores potenciais hídricos) que a dos estratos inferiores, por sofrerem mais diretamente as variações dos fatores meteorológicos que as últimas.

Vimos quanto à fenofase árvores com foIhas novas, que $70,37 \%$ das espécies apresentaram-se com esta característica durante a estação seca.

Longman \& Jenik (1974) afirmam que, nas florestas sasonais sempre verdes, a emissão de folhas freqüentemente ocorre na estação seca e os brotos emergem algum tempo antes das chuvas começarem e que o "flushing" é geralmente dito ser causado pelas chuvas, não sendo verdadeiro, todavia, para muitas espécies que iniciam o crescimento na estação seca.

Njoku (1963), em seus estudos preliminares com Terminalia superba, Bosqueia angolensis e Millettia thoningii, notou que os brotos estavam num estado de "post dormência". Deste modo, eles estavam provavelmente parados durante aquele tempo, requerendo apenas um aumento no suprimento de água para a quebra do broto (bud-break), do mesmo modo como na semente pode faltar somente água para ocorrer a germinação.

Njoku (1964) mostrou que diversas árvores tropicais são sensiveis ao fotoperiodismo e presumivelmente as taxas de "prolongamento do broto" sob condições naturais na floresta são parcialmente uma função deste fator.

Muitos fatores podem influenciar a queda das folhas: baixa intensidade de luz, mudança de temperatura, comprimento do dia, deficiência mineral, redução no tecido fotossintético e de transpiração, a tensão de água e danos causados por agentes mecânicos ou pragas (Longman \& Jenik 1974); estes autores acham que a significância da mudança de folhas provavelmente repousa na balança entre a máxima fotossintese e o mínimo de tensão de água e que o crescimento das folhas pode ser in. fluenciado também pela nutrição mineral.

Nos resultados apresentados, vimos que a árvore com pouca folha ou desfolhada ocorreu para a maioria das espécies também na estação seca. Mas, conforme mostram os gráficos das espécies, (1 a 27) houve uma queda de folhas durante todo 0 ano.

Kiinge \& Rodrigues (1968), estudando a produção de manta vegetal (ou liteira) numa área de floresta de terra firme (Reserva Walter Egler), $\mathrm{Km} 65$ da Manaus-Itacoatiara, muito semelhante à área deste estudo, também encontraram que a queda de detritos (folhas e outros) ocorre durante todo o ano, mas que a manta formada durante a estação seca (junho a outubro) correspondeu a $50 \%$ da produçãa anual.

Baker \& Baker (1936), nas Novas Hebridas; Beard (1946), em Trinidad; Holttum (1931), em Singapura; Madge (1965) e Hopkins (1966), na Nigéria; Taylor (1960), em Ghana; Araujo (1970), na Amazônia e Frankie, Baker \& Opler (1974), na Costa Rica, já observaram em muitos tipos florestais tropicais que a máxima queda de folhas ocorre também durante o período seco do ano.

Verificamos (Tabela 5), para as 27 espécies estudadas quanto à duração da floração e frutificação, que a maior freqüência ocorreu em 3 e 5 meses, respectivamente. (Veja Tabelas 3 e 4). A duração da frutificação foi sempre mais longa do que a da floração.

Concluímos, ainda, (Tabela 6) que o tempo de vida das folhas não foi regular no período de 12 anos. A maioria das espécies estudadas é perenifólia.

\section{AGRADECIMENTOS}

Os autores agradecem a colaboração do Dr. Warwick Estevam Kerr, diretor do INPA, pela orientação e incentivo prestados para a publicação deste trabalho; agradecemos ao $\mathrm{Dr}$. Alejo von der Pahlen pelas correções e sugestões no texto; agradecemos também ao Departamento de Botânica nas pessoas da Dra. 
Izonete Araújo, pela identificação do material; Dra. Marlene Freitas da Silva, Curadora do Herbário do INPA e Dr. William Rodrigues, Chefe da Divisão de Biologia, pela revisão final dos nomes científicos.

Queremos aında agradecer ao Matemático Álvaro Vieira do Setor de Computação do INPA pela valiosa ajuda prestada na análise estatística das observações; ao Sr. Francisco Melo e Sr. Dionizio Coelho, do Departamento de Botânica, pela ajuda no controle, secagem e herborização do material; aos nossos Auxiliares Técnicos João Aluisio da Costa Sousa, Lourival Quintiliano Reis, pelo zelo e dedicação com que coiaboraram nas observações de campo, ao Técnico Agrícola Othoniel Rodrigues Lyra Filho, pelos desenhos dos gráficos e Ralfh João Ribeiro pela datilografia do texto.

\section{SUMMARY}

This paper presents phenological observations of 27 tree species in a humid tropical forest of the Amazonian terra firme, located in the Ducke Reserve, near Manaus, Brazil, during the period from 1965 to 1976. Trees were selected for observation on the basis of superior phenotypic characteristics; species were selected on the basis of their economic value in local, national and international markets as sources of timber, essential oils, resins, gums, latex and fruits. The followinb phenological phenomena are analyzed: flowering, fruiting, and production of new leaves. Phenological observations were made in separate trees occupying different strata of the forest. Over the 12 years of observations, the periodicity of initiation of flowering and fruiting is shown for each species and for all species. In addition, the most probable periods and durations of flowering and fruiting are shown for each species, as well as dendrological and botanical characteristics. After lumping data on the initiation of flowering and fruiting for all species, the two samples (trees occupying canopy and trees occupying lower canopy) were compared by use of the non-parametric $\mathrm{H}$ test of Kruskal Wallis. The samples were shown to be significantly different, indicating that the crown position is an important factor of phenological hehavior. A simple regression analysis correlates phenological data (initiation of flowering and fruiting) with climatic factors (precipitation, relative humidity and maximum absolute temperature). When there are small values of precipitation and relative humidity the results tend to show a greater number of trees initiating flowering and fruiting. Maximum absolute temperature was r.ot significant to flowering yet was significant $(0,1 \%)$ to fruiting and having a positive correlation (to greater values of this temperature a larger number of trees will be found initiating fruiting).

\section{BIBLIOGRAFIA}

Alvin, P.T.

1958 - Estímulo de la floración y frutificación del cafeto por aspersiones con acido giberélico. Turrialba, 8(2).

1960 - Moisture stress as a requirement for flowering of coffee. Reprint Series. Inter-American Institute of Agricultural Sciences n..$^{\circ}$ 140. Reprinted From Science, 132(3423) : 354.

1966 - Factors affecting flowering of the cocoa tree. Cocoa Grower's Bulletin, (7): 15-19.

- Fatores que controlam a floração do cafeeiro. Centro de Pesquisas do $\mathrm{Ca}$ cau. Itabuna-Bahia. $18 \mathrm{p}$. Mimeografado.

Araujo, V.C.

1970 - Fenologia de essências florestais amazônicas. I. - Boletim do INPA. (4) : $25 \mathrm{p}$. Manaus.

AshToN, P.S.

1969 - Speciation among tropical forest trees: some dedutions in the light of recent evidence. Biol. J. Iinn. Soc., 1:155-196.

Aubréville, A.

1938 - La forêt coloniale: Les forêts de l'Afrique occidentale francaise. Annls Acad. Sci. Colon., 9:1-245.

BAKER, H.G.

1973 - Evolucionary relationships between flowering plants and animals in American and African tropical forests. Tropical forest ecosystems in Africa and South America: a comparative review. Association for Tropical Biology, Washington, Parag. 2.8.

BAKER, J.R. \& BAKER, I.

1936 - The seasons in a tropical rain - forest (New Hebrides). Part. 2 Botany. J. Linn. Soc. (Zol.) $39: 507-519$.

BAWA, K.S.

1974 - Breeding systems of tree species of a low land tropical community and their evolutionary significance. Evolution, Lancaster, $28: 85-92$.

BEARD, J.S.

1946 - The natural vegetation of Trinidad. Oxf. Ford. Mem, 20. Clarendon Press. Oxford. $152 \mathrm{p}$. 
BEWS, J.W.

1927 - Studies in the ecological evolution of the angiosperms. New Phytol., 26:209-248.

Brinkmann, W.L.; Weinman, J.A. \& Ribeiro, M.N.G. 1971 - Air temperatures in Central Amazônia. 1. The daily record of air temperatures in a secondary forest near Manaus under cold front conditions (July $4^{\text {th }}$, to July $13^{\text {th }}$, 1969). Acta Amazonica, 1(1):75-76.

BROWNING, G.

1971 - The hormonal regulation of flowering and cropping in Coffea arabica. $\mathrm{Ph}$. D. Thesis. University of Bristol, $136 \mathrm{p}$.

CONCEIÇão, P. Nonato DA

1977 - Alguns aspectos ecofisiológicos da floresta tropical úmida de terra firme. Acta Amazonica, 7(2) : 157-178

Cront, T.B.

1969 - Seasonal flowering behavior in Central Panama. Ann. Missouri Bot. Garden, $56: 295-307$.

DAUBENMIRE, $R$.

1972 - Phenology and other characteristics of tropical semi-deciduos forest in North - Western - Costa Rica. Journal of Ecology, 60(1) : 147-170.

DUCKE, A. \& BLACK, G.A.

1953 - Phytogeografical notes on Brazilian Amazon. Anais Acad. Bra. Cienc., $25: 1-46$.

FrankIE, G.W.; BAKer, H.G. \& Opler, P.A.

1914 - Comparative phenological studies of trees in tropical wet and dry forests in the Lowlands of Costa Rica. Journal of Ecology, 62(3) : 881-919.

Holttum, R.E.

1931 - On periodic leaf-change and flowering of trees in Singapore. Gardens Bull., Singapore, 5:173-206.

1953 - Evolutionary trends in a equatorial climate. Soc, Exp. Biol. Symp., 7:159-173.

Hopp, R.J.

1974 - Plant Phenology observation networks. In: Phenology and Seasonality modeling. Chapman \& Hall Limited. 25:43, London.

HoPKINS, B.

1966 - Vegetation of the Olokemeji Forest Reserve, Nigeria. IV. The litter and soil with special reference to their seasonal changes. Journal of Ecology, 54:687-703.

JANZEN, D.H.

1971 - Euglossine bees as long-distance pollinators of tropical plants. Science, N.Y. $171:$ 203-205.
Klinge, H. \& Rodrigues, W.A.

1968 - Litter production in an area of Ama. zonian Terra Firme Forest. Part I Litter-Fall, Organic carbon and total Nitrogen Contents of litter. Amazoniana, I (4) : 287-301.

Klinge, H. \& Sioli, H.

1962 - Solos, tipos de vegetaçāo e águas na Amazônia. INPA - Boletim do Museu Paraense Emilio Goeldi, Avulsa (separata) (1) : 27-41. Belém.

LONGMAN, K.A. \& JeniK, J.

1974 - Tropical forest and its environment. Tropical Ecology Series, 196 p. London.

MACEDO, M.

1977 - Dispersão de plantas lenhosas de uma campina Amazônica. Acta Amazonica, (Suplemento) $7(1): 1-69$

MADGE, D.S

1965 - Leaf fall and litter disappearance in a tropical forest. Pedobiologia, 5:273-288.

MEDWAY, LORD

1972 - Phenology of a tropical rain forest in Malaya. Biol. J. Linn, Soc., 4:117-146.

NJOKU, E.

1963 - Seasonal periodicity in the growth and development of some forest trees in Nigeria. I - Observations on mature trees. Journal of Ecology, 51:617-624.

1964 - Seasonal periodicity in the growth and development of some forest trees in Nigeria. Journal of Ecology, 52: 19-26.

Prance, G.T.; Rodrigues, W.A. \& Silva, M.F.

1976 - Inventário florestal de um hectare de mata de terra firme $\mathrm{Km} 30$ da estrada Manaus-Itacoatiara. Acta Amazonica, 6(1) : 9-35

Piringer, A.A. \& BORTHWICK, H.A.

1955 - Photoperiodic responses of coffee. Turrialba, $5(3): 72-77$.

RAYNER, R.W

1942 - A progress report of investigations on flowering in coffee. The coffee Board of Kenya. Monthly Bulletin, 7(6) : 42-44.

REES, A.R

1964 - Some observations on the flowering behaviour of Coffea rupestris in Sou thern Nigeria. Journal of Ecology, $52: 1-7$.

RIBEIRO, M.N.G.

1976 - Aspectos climatológicos de Manaus. Acta Amazonica, 6(2) : 229-233.

1977 - Boletim Meteorológico. Estação Meteo. lógica (Reserva Ducke Anos: 1974, 1975 e 1976. Mimeografado. 
RICHIRDS, P.W.

1952 - The tropical Rain Forest. An Ecological Study. Cambridge University Press London. $450 \mathrm{p}$.

Schulz, J.P.

1960 - Ecological studies on the rain forest of northern Surinam. The vegetation of Surinam, Vol, 2 North - Holland. Amsterdam. Paragr. (3.6-4.1).

SHIELD, E.D.

1965 - Silvicultural scoring of stem form. In: The application of new sampling methods to previously inaccessible tropical forest areas with particular reference to Papua. New Guinea. Diploma Thesis C.F.I. Oxford.

TAYLOR, C.J.

1960 - Synecology and Silviculture in Ghana. Nelson. Edinburg.
WENT, F.W

1957 - The experimental control of plant grownth. Walthem. Mass., Chronica Botanica Co. $343 \mathrm{p}$.

WIELgolaski, F.E.

1974 - Phenology in agriculture. In: Phenology and seasonality modeling, Chapman \& Hall limited. $369: 381$. London.

WHITMORE, T.C.

1975 - Tropical rain Forests of the far east. Clarendon Press, 282 p. Oxford - England.

1959-63 - Silvicultural scoring of crown form and crown position. In: Uganda Silvicultural Research Plan, Parag. 14:2-3.

(Aceito para publicação em $03 / 06 / 78$ ) 
